University of Massachusetts Amherst

ScholarWorks@UMass Amherst

August 2019

\title{
In-situ Zircon and Monazite Geochronology from Compositionally Distinct Layers in a Single Migmatitic Paragneiss Sample Located in the Eastern Adirondack Mountains, NY
}

Kaitlyn Suarez

University of Massachusetts Amherst

Follow this and additional works at: https://scholarworks.umass.edu/masters_theses_2

Part of the Geology Commons, and the Tectonics and Structure Commons

\section{Recommended Citation}

Suarez, Kaitlyn, "In-situ Zircon and Monazite Geochronology from Compositionally Distinct Layers in a Single Migmatitic Paragneiss Sample Located in the Eastern Adirondack Mountains, NY" (2019). Masters Theses. 799.

https://doi.org/10.7275/14223276 https://scholarworks.umass.edu/masters_theses_2/799

This Open Access Thesis is brought to you for free and open access by the Dissertations and Theses at ScholarWorks@UMass Amherst. It has been accepted for inclusion in Masters Theses by an authorized administrator of ScholarWorks@UMass Amherst. For more information, please contact scholarworks@library.umass.edu. 
IN-SITU ZIRCON AND MONAZITE GEOCHRONOLOGY FROM COMPOSITIONALLY DISTINCT LAYERS IN A SINGLE MIGMATITC PARAGNEISS SAMPLE LOCATED IN THE EASTERN ADIRONDACK MOUNTAINS, NY

\author{
A Thesis Presented \\ by \\ KAITLYN A. SUAREZ
}

Submitted to the Graduate School of the

University of Massachusetts Amherst in partial fulfillment of the requirements for the degree of

MASTER OF SCIENCE

May 2019

Geosciences 
(C) Copyright by Kaitlyn A. Suarez 2019

All Rights Reserved 
IN-SITU ZIRCON AND MONAZITE GEOCHRONOLOGY FROM COMPOSITIONALLY DISTINCT LAYERS IN A SINGLE MIGMATITIC PARAGNEISS SAMPLE LOCATED IN THE EASTERN ADIRONDACK MOUNTAINS, NY

\author{
A Thesis Presented \\ by \\ KAITLYN A. SUAREZ
}

Approved as to style and content by:

Michael Williams, Chair

Michael Jercinovic, Member

Timothy Grover, Member

Julie Brigham-Grette, Department Head

Geosciences 


\section{DEDICATION}

This work is dedicated to my parents, Joseph and Kalliopi Suarez, for encouraging my dreams and for supporting me in every step of the journey. This work is also dedicated to my siblings, Kristen and James, for being a constant source of inspiration and motivation, and for being there for me when I need it the most. 


\section{ACKNOWLEDGMENTS}

My sincerest thank you to my advisors, Michael Williams, Timothy Grover, Michael Jercinovic, and Sheila Seaman, for their time and dedication to enriching my education. Your passion, kindness, commitment, and enthusiasm has truly inspired me. I am very excited to continue working in the field of tectonics with you all. I am grateful for the twist of fate that brought me to the University of Massachusetts Amherst.

I would like to give a big thank you to Claire Pless for her guidance, support, mentorship, and friendship. I would also like to acknowledge my peers at Castleton University, Ashely Smith and Eric Baurle, for their friendship, comradery, and assistance in the field and laboratory. Thank you to my dad for assisting me with fieldwork, and especially for carrying all those rocks, in the Adirondack Mountains, NY. The work is truly a collaborative effort and would not be possible without enthusiasm and participation from everyone.

This research was made possible by the National Science Foundation through grant NSF-1419876 (to Michael Williams and Timothy Grover) in addition to the National Science Foundation Graduate Research Fellowship Program under Grant No. 1451512. The U/Pb zircon dates were analyzed at the Arizona LaserChron Center, which is an NSF multi-user facility run by Mark Pecha and George Gehrels at the University of Arizona. 


\begin{abstract}
IN-SITU ZIRCON AND MONAZITE GEOCHRONOLOGY FROM COMPOSITIONALLY DISTINCT LAYERS IN A SINGLE MIGMATITIC PARAGNEISS SAMPLE LOCATED IN THE EASTERN ADIRONDACK MOUNTAINS, NY
\end{abstract}

MAY 2019

\author{
KAITLYN SUAREZ, B.S., UNION COLLEGE \\ M.S., UNIVERSITY OF MASSACHUSETTS AMHERST
}

Directed by: Professor Michael Williams

Migmatites are a common rock type in the Adirondack Mountains, NY. We analyzed a single sample of biotite-garnet-sillimanite paragneiss with foliation parallel leucosome along Route 22 south of Whitehall, NY in order to determine the timing of melting using both in-situ monazite and zircon $\mathrm{U} / \mathrm{Pb}$ geochronology from the restite and leucosome layers of the same rock. Monazite was analyzed via in-situ EMPA on the Ultrachron microprobe at the University of Massachusetts. Zircon was analyzed via LAICP-MS (in-situ and mounted mineral separates) at the LaserChron Center. Monazite analyses from the restite yielded six compositionally distinct populations with dates of $1178 \pm 16,1139 \pm 4,1064 \pm 6,1049 \pm 4,1030 \pm 5$, and $1004 \pm 10 \mathrm{Ma}$. Yttrium and heavy REEs decrease in monazite in two steps: one dramatic drop from ca. 1150 to 1065 Ma and another between ca. 1065 and 1050, interpreted to reflect two periods of garnet growth and melting. Analyses from the restite zircon separate yielded a significant single peak near $1050 \mathrm{Ma}$. These zircon grains exhibit fir-tree sector zoning texture which is interpreted to indicate crystallization from melt. Monazite from leucosome yielded a unimodal population at ca. $1050 \mathrm{Ma}$, however, backscatter images document alteration of monazite to apatite on the edges of the grains, and abundant uranothorite inclusions. 
Leucosome zircon analyses yielded a ca. 1150 Ma population from cores and a $1050 \mathrm{Ma}$ population from rims. Cathodoluminescence imaging reveals that the zircon rims have textures indicative of fluid alteration. The data are consistent with these rocks undergoing two periods of melting. The first event at ca. 1150 Ma may have involved a non-garnet producing melting reaction, such as muscovite dehydration-melting. The second event at $1065 \mathrm{Ma}$ involved significant garnet growth, interpreted to represent biotite dehydrationmelting. Subsequently, the rocks underwent hydrothermal alteration at $1050 \mathrm{Ma}$.

Monazite grains with dates at $1030 \pm 5$ and $1004 \pm 10$ Ma have higher yttrium concentrations suggesting garnet breakdown and monazite growth during decompression and retrograde metamorphism. A combination of monazite and zircon dating techniques from each compositional layer is necessary to constrain leucosome-restite relationships and to accurately interpret the timing of melting from migmatites that have experienced multiple phases of melting. 


\section{TABLE OF CONTENTS}

ACKNOWLEDGMENTS

Page

ABSTRACT.

LIST OF TABLES. vi

LIST OF FIGURES ix CHAPTER

1. INTRODUCTION 1

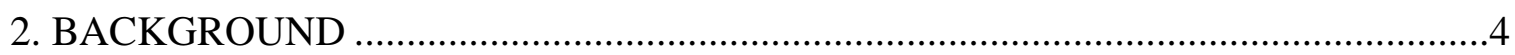

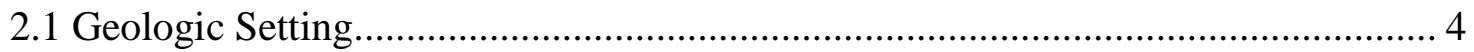

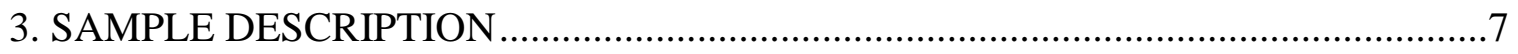

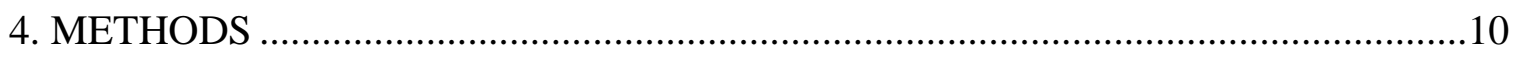

4.1 Monazite U-Th-Pb Geochronology Methods ................................................... 10

4.2 Zircon U-Pb Geochronology Methods.......................................................... 14

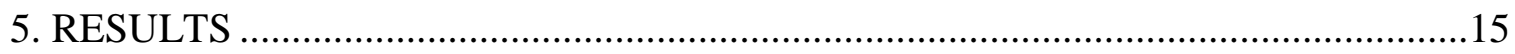

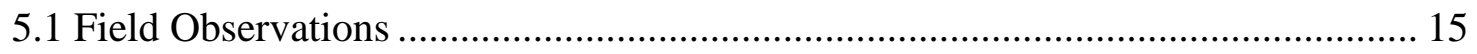

5.2 Restite Monazite Results................................................................................. 15

5.3 Restite Monazite Composition-Date Relationships .......................................... 18

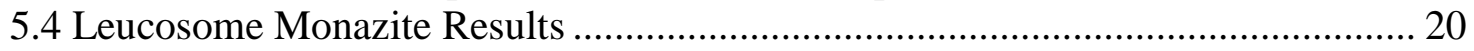

5.5 Leucosome and Restite Monazite Compositional Comparison ............................ 22

5.6 In-situ Restite Zircon Results........................................................................... 24

5.7 Separate Restite Zircon Results ....................................................................... 26

5.8 In-situ Leucosome Zircon Results ................................................................. 28

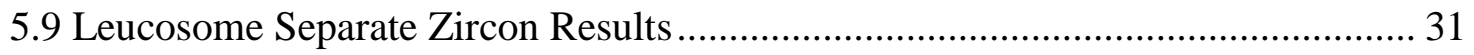

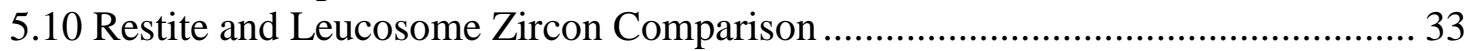

5.11 Thin Section Scale Compositional Comparison ............................................. 34

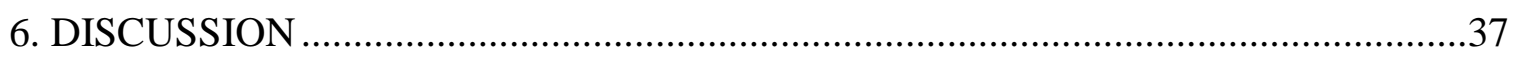

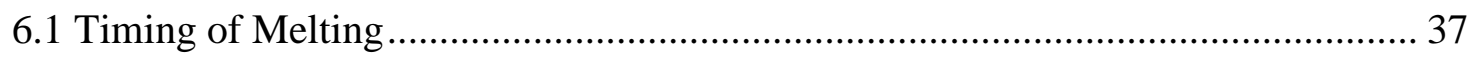

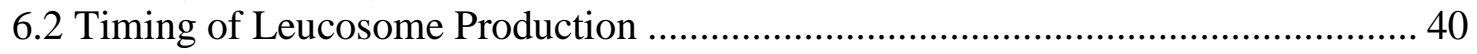

6.3 Retrograde Metamorphism, Decompression, and Fluid Influx ........................... 45

6.4 Evidence for Heterogeneous Melting ............................................................ 48

6.5 Overview of Metamorphic and Deformational History ...................................... 49

6.6 Limitations of Zircon and Monazite Geochronology ....................................... 50

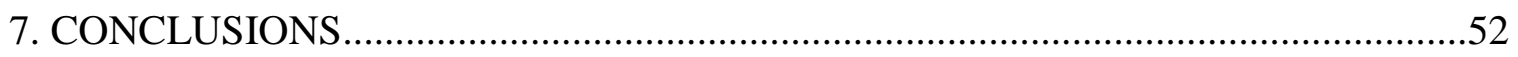

APPENDICES

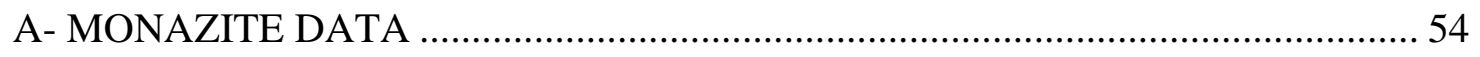

B - ZIRCON DATA.............................................................................................. 58

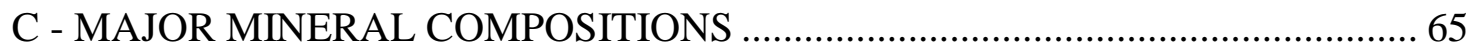

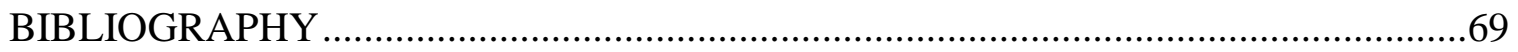




\section{LIST OF TABLES}

Table

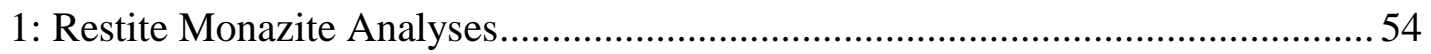

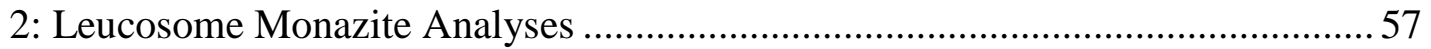

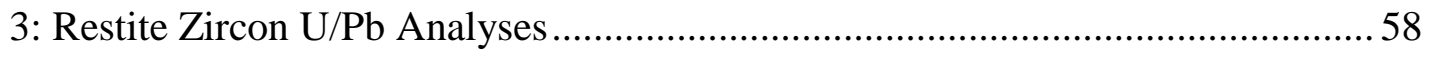

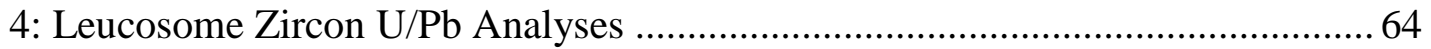




\section{LIST OF FIGURES}

Figure $\quad$ Page

1: Geologic map of the Adirondack Mountains, NY .......................................... 6

2: Photo of the road cut outcrop facing west along Rt. 22 south of Whitehall, NY where the paragnesis samples were collected............................... 8

3: Sample 16TG-143 is representative of the garnet-biotite-sillimanite paragneisses collected in the study.

4: Full section X-ray maps of $\mathrm{Ca}, \mathrm{K}$, and Mg for samples 16-TG-143-1

(restite), 16-TG-143-2 (restite + leucosome), and 16-TG-143-5

(leucosome)

5: Full-section map (16-TG-144) with arrows connecting monazite grain maps to the monazite location in the thin section in order to evaluate the textural and zoning significance

6: Schematic and yttrium $\mathrm{x}$-ray map showing the three compositional zones and associated dates for a monazite grain in the restite.

7: Monazite date results from the restite layer................................................ 17

8: Restite monazite composition vs calculated date. ........................................... 19

9: A) BSE images of the leucosome (16TG-143-5) monazite with uranothorite inclusions and alteration to apatite on the edges................................ 21

10: Monazite date results from the leucosome layer. ......................................... 22

11: Comparison of the restite and leucosome monazite compositions for $\mathrm{Y}$, HREE, U, LREE, Th and Ca against calculated date ........................ 23



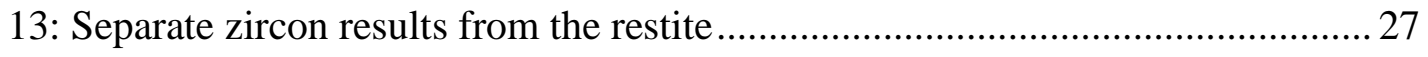

14: In-situ and separate restite zircon dates plotted against uranium ...................... 28

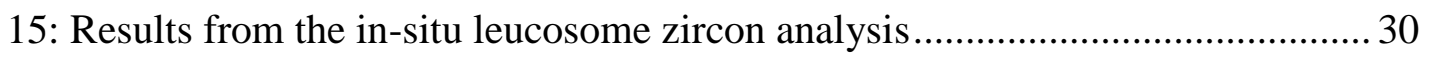

16: Results from the leucosome separate zircon analysis................................... 32

17: Th/U vs. Date for the leucosome and restite zircon grains from both in-situ and separate analyses. 
18: A) Magnesium and potassium x-ray maps of 16-TG-143-1 with lines delineating the layers in the thin section that are inferred to have retained melt (plagioclase-rich) and lost melt (K-feldspar-rich).

19: Comparison of monazite composition vs date between the K-feldspar and

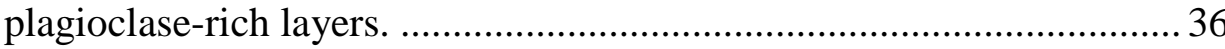

20: Restite monazite results with the interpreted tectonic event

21: Comparison of the restite and leucosome monazite and zircon grains with associated dates.

22: Schematic showing the interpreted timeline of melting, garnet growth, monazite growth, and zircon crystallization based on the data from the restite layers

23: Comparison of the composition of garnet in all samples (restite and leucosome) 65

24: Calcium x-ray microprobe maps of the garnet grains analyzed in the restite..... 66

25: Calcium x-ray microprobe maps of the garnet grains analyzed in the leucosome

26: Comparison of the composition of K-feldspar in the restite (143-1) and leucosome (143-5) 68

27: Potassium x-ray microprobe map of K-feldspar in the leucosome (143-5)........ 68

28: Compositional comparison of plagioclase in the restite (143-1) and leucosome (143-5) 69

29: Calcium x-ray microprobe map of plagioclase in the leucosome (143-5) 69 


\section{CHAPTER 1}

\section{INTRODUCTION}

Monazite ((Ce, $\left.\mathrm{La}, \mathrm{Th}) \mathrm{PO}_{4}\right)$ is a powerful geochronometer for revealing the timing of melting during high-temperature metamorphism (Williams et al., 2011; Wong et al., 2012; Wang et al., 2017). Monazite is particularly useful for "reaction dating" (petrochronology) (Williams et al., 2017), a method in which in-situ monazite dates and associated geochemistry are linked to specific melt reactions, such as biotite dehydrationmelting (Dumond et al., 2015; Williams et al., 2017; Williams et al., in review). Monazite petrochronology has provided a number of insights about the prograde and retrograde path during partial melting events. However, there are issues that complicate interpretations, especially in near peak metamorphism, one of which is that monazite can be quite soluble in some granitic melts, and therefore data from zircon may provide additional constraints (Kelsey et al., 2008). Zircon is also a commonly used geochronometer, however there are fewer studies relating zircon growth to melt reactions due, in part, to the low abundance of trace elements in zircon (Bickford et al., 2008; Rubatto, 2017). Trace elements in geochronometers can provide a number of insights into orogenic processes (Rubatto, 2017; Williams et al., in review). Zircon is a key mineral for constraining the timing of melting because zircon is durable in melt and has been shown to grow from crystallizing partial melt (Rubatto, 2017). The combination of zircon petrochronology and monazite petrochronology may provide the most complete record of melting, melt crystallization, exotic melt injection, and melt extraction events in migmatites, especially in multiply melted regions. 
The rocks of Adirondack Mountains of New York are uplifted Precambrian basement of the North American Grenville Province that are interpreted to have undergone multistage melting and deformation (Rivers, 1997; Chiranzelli et. al., 2017). Previous studies have delineated the timing of the Mesoproterozic events, and it is widely accepted that two events may have contributed to widespread melting and garnet growth: 1) the (ca. 1190-1140 Ma) Shawinigan Orogeny and associated (ca. 1160-1140 Ma) anorthosite-mangerite-charnockite-granite (AMCG) plutonism and 2) the (ca. 1080 $1020 \mathrm{Ma})$ Ottawan Orogeny and associated unroofing and tectonic collapse phase (Rivers, 1997; McLelland and Selleck, 2011; Wong et al., 2012; Regan et al., in review; Williams et al., in review). Curiously, some migmatitic rocks in the eastern Adirondack Mountains record either the older (ca. $1150 \mathrm{Ma}$ ) or the younger (ca. $1050 \mathrm{Ma}$ ) melt history, but not both events (Williams et al., in review; Pless et al., pers comm). A close examination of the layers of a migmatite may elucidate the reasons for the heterogeneities in the record of melting in order to better understand the timing of melting in the Adirondack Mountains in general (Williams et al., 2017; Williams et al., in review).

Metapelitic migmatitc paragneiss outrcrops are present along highway 22 south of Whitehall, NY. Previous work on these outcrops show that monazite grew during both the Shawinigan and Ottawan orogenies (Wong et al., 2012), thus making this location a suitable focus for our study. We analyzed rock-scale and thin-section scale restite and leucosome layers in order to better understand the monazite and zircon geochronological record, geochemistry, and growth/dissolution during anatexis. This study explores links between monazite/zircon crystallization and melting reactions, such as biotite dehydration-melting, and aims to 1) clarify the timing of melting in the eastern 
Adirondack Mountains through combined in-situ zircon and monazite petrochronology and 2) explore the mineral assemblage and geochronological heterogeneities between the restite and leucosome layers in order to interpret the record of melting and melt crystallization in migmatitic rocks. 


\section{CHAPTER 2}

\section{BACKGROUND}

\subsection{Geologic Setting}

The Adirondack Mountains are a domical uplift and outlier of the Grenville Province rocks in upstate New York (Figure 1). They are connected to the Grenville Province exposed in eastern Canada by the Fronteac Arc. The Grenville Province of eastern and southern North America are the products of a protracted period of Mesoproterozoic orogenesis and accretion along the eastern margin of Laurentia, the culmination of which resulted in the formation of the supercontinent Rodinia (Rivers, 1997; Chiranzelli et. al., 2017). The Adirondack Mountains are predominantly composed of a lithologically and compositionally diverse suite of high-grade metasedimenary and metaigneous rocks. The northeast-trending Carthage Colton Shear zone forms the boundary between the Adirondack Lowlands to the northwest and the Adirondack Highlands to the southeast. The Highlands and the Lowlands have overlapping yet distinctly different geologic histories (Figure 1) (McLelland and Selleck, 2011).

The Adirondack Mountains record a series of Mesoproterozoic accretionary/collisional orogenic events. The (ca. 1245-1225 Ma) Elzevirian orogeny is interpreted to represent a phase of magmatism and metamorphism related to the accretion of the Elzevir terrane (Rivers, 1997). The (ca. 1190 - 1140 Ma) Shawinigan orogeny involved thrusting, crustal thickening, and regional granulite facies metamorphism in the Adirondack Highlands. It is interpreted to represent the closure of the trans-Adirondack basin and subsequent back arc collisional tectonism (Rivers, 1997; Heumann et al., 2006;

Chiarenzelli et al., 2010 Wong et. al., 2012). The Adirondack Lowlands are interpreted to 
have been thrusted over the Highlands along the Carthage-Colton shear zone following the closure of the trans-Adirondack basin. Emplacement of a major suite of intrusive igneous rocks including anorthosite-mangerite-charnockite-granite and gabbro known as the AMCG suite (1165-1145 Ma) is interpreted to be a result of delamination of the lithospheric mantle (Chiarenzelli et al., 2010). The (ca. 1080 - 1020 Ma) Ottawan orogeny resulted in granulite-facies metamorphism in the Adirondack Highlands. It is interpreted to represent a Himalayan-style continent-to-continent collision, possibly between Laurentia and Amazonia (Rivers, 1997, Heumann et al., 2006; Bickford et. al., 2008; Wong et. al., 2012). The Adirondack Highlands likely reached temperatures near $800{ }^{\circ} \mathrm{C}$ and 7-9 kbar during the Ottawan orogeny (Spear and Markesson, 1997; Storm and Spear, 2005). The Rigolet orogeny is interpreted to be a significant event in the western Grenville Province. However, in the Adirondack Mountains the Rigolet event is characterized by metasomatism and pegmatite emplacement with minimal structural or metamorphic impact (Rivers, 2008; Williams et al, in review).

Outcrops along Rt. 22 south of Whitehall, NY have been recently interpreted to record evidence of a shear zone that accommodated extension during the later stages of the Ottawan orogeny (Wong et al., 2012). The Eastern Adirondack shear zone is interpreted to have undergone top-to-the-southeast normal faulting synchronous with topto-the-northwest normal shearing on the Carthage Colton shear zone in the western Adirondack Highlands (Wong et al., 2012). The Adirondack Highlands may have been exhumed as a metamorphic core complex or symmetrical gneiss dome during the latestage gravitational collapse of the Ottawan orogeny (Wong et al., 2012; Regan et al., in press). 


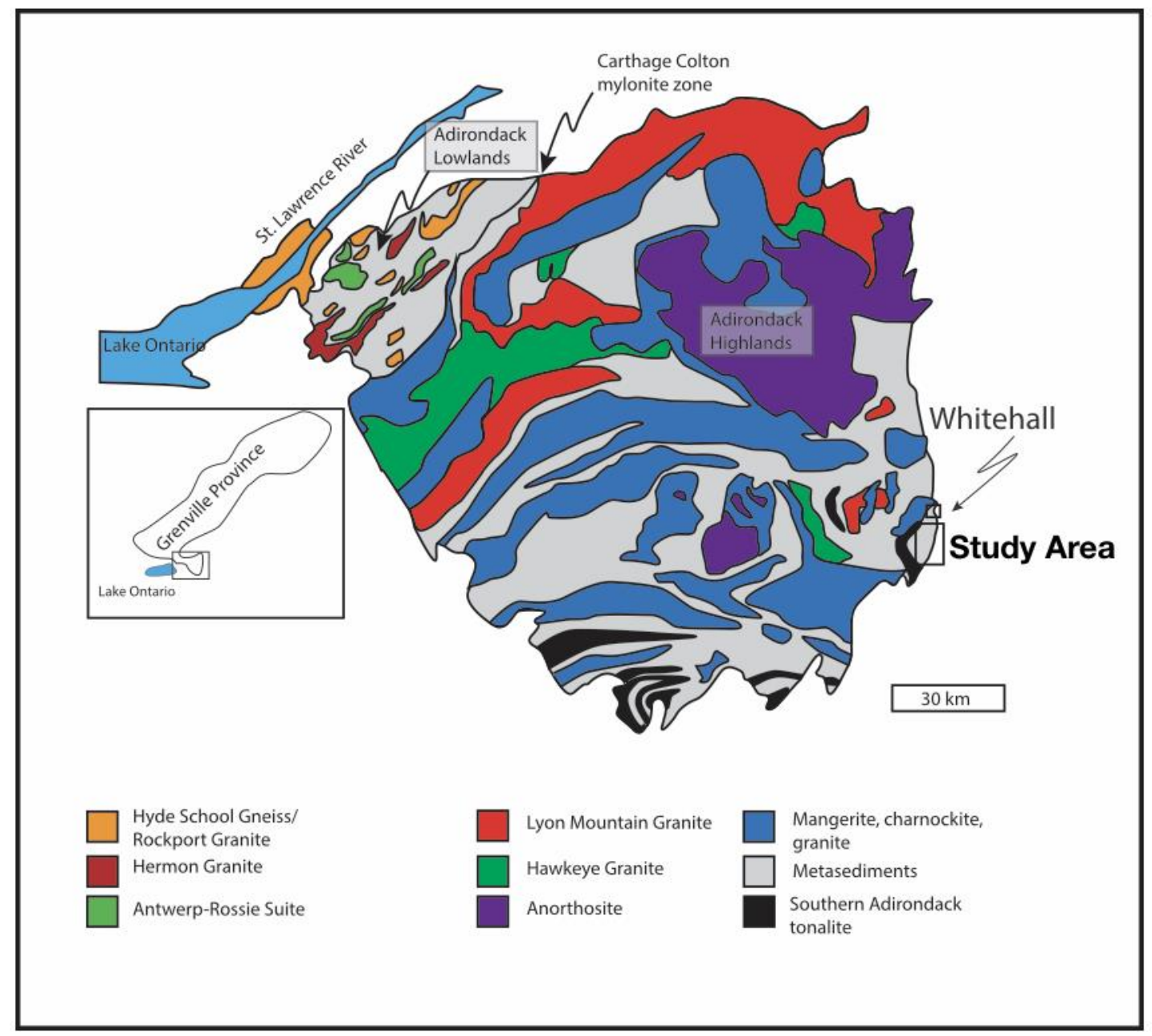

Figure 1: Geologic map of the Adirondack Mountains, NY. The study area is along Rt. 22 south of Whitehall, NY. The inset shows the location of the Adirondack Mountains relative the Grenville Province in Canada. Modified from McLelland et al., 2013. 


\section{CHAPTER 3}

\section{SAMPLE DESCRIPTION}

Two paragneiss samples, 16-TG-143 and 16-TG-144, were collected from a road cut south of Whitehall, NY (Figure 2). The two paragneiss samples are composed of a mineral assemblage of biotite, garnet, sillimanite, plagioclase, quartz, K-feldspar with zircon, monazite, rutile, and ilmenite as accessory phases. Sample 16-TG-143 was selected because the sample has discrete restite and leucosome layers, including one larger $(3 \mathrm{~cm})$ garnet-rich leucosome layer (Figure 3). Sample 16-TG-144 is distinct from sample 16-TG-143 in that there is very coarse garnet and sillimanite with discrete, thin leucosome layers. The restite and leucosome layers were separately analyzed in order to evaluate the melting history in each layer. Four polished sections that are representative of the restite and leucosome layers from both samples were selected for monazite and zircon dating. 


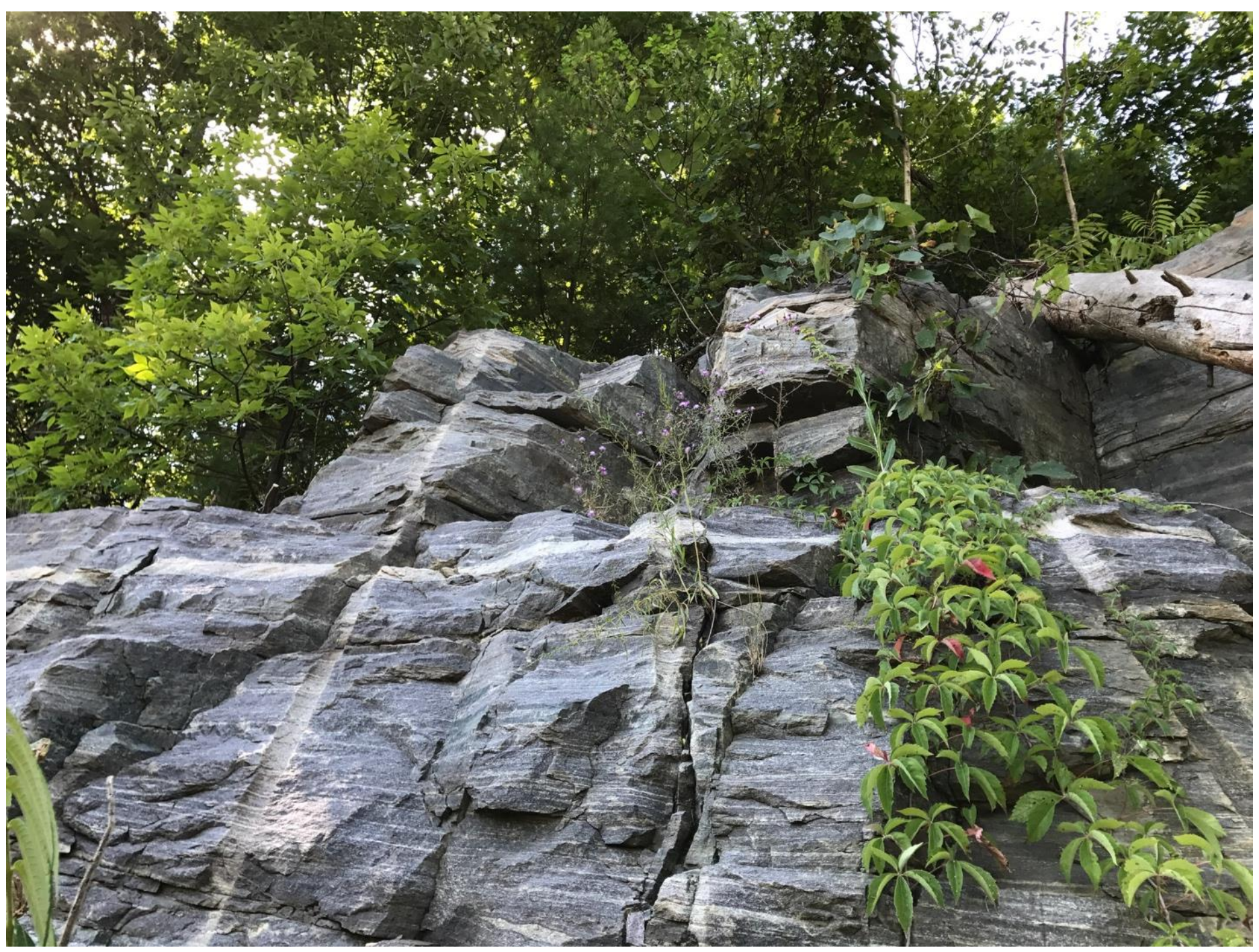

Figure 2: Photo of the road cut outcrop facing west along Rt. 22 south of Whitehall, NY where the paragneiss samples were collected. A leucosome vein is present in the upper left corner. 


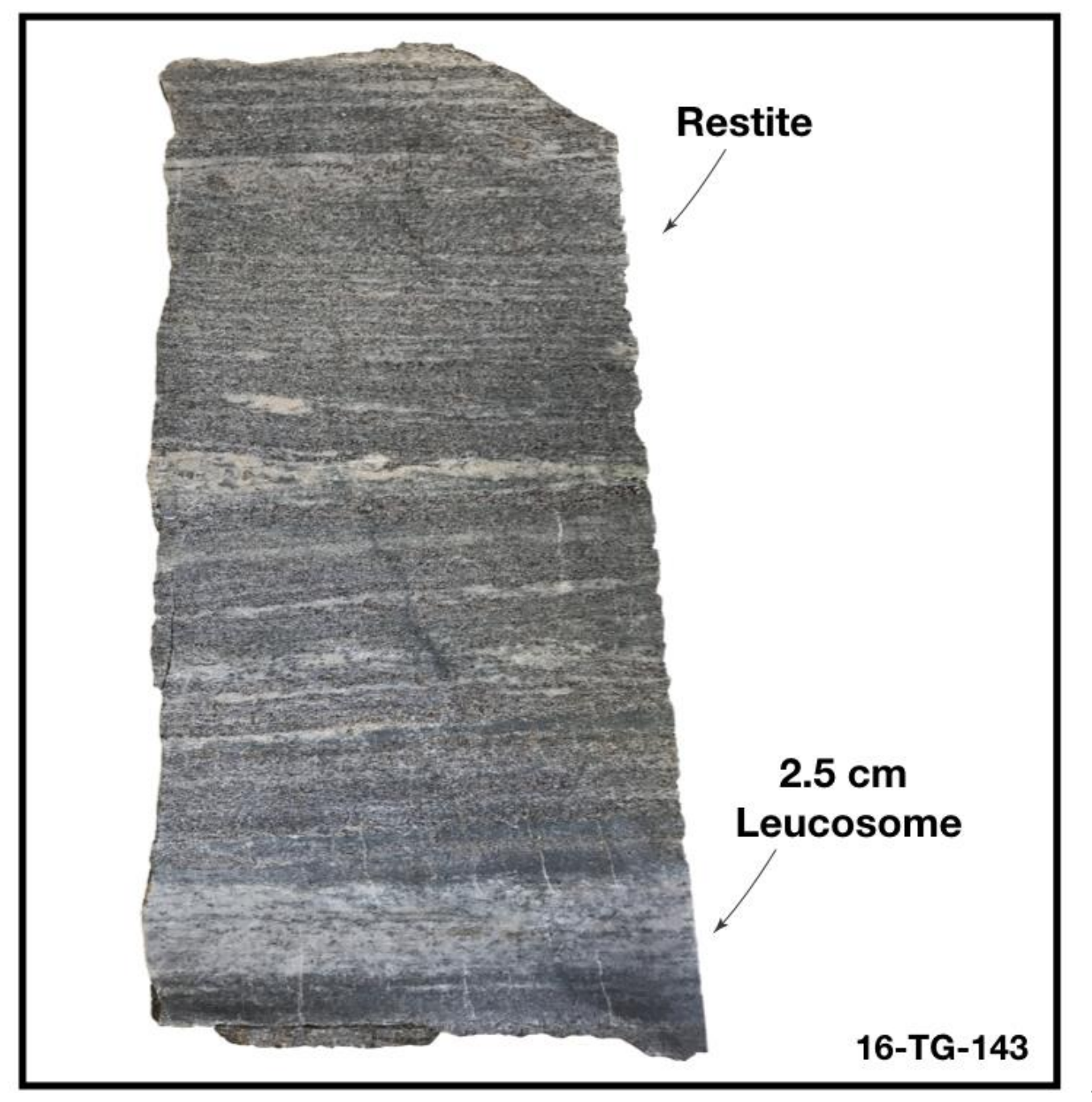

Figure 3: Sample 16TG-143 is representative of the garnet-biotite-sillimanite paragneisses collected in the study. The top of the sample is mostly restitic with layers and the bottom layer has a $2.5 \mathrm{~cm}$ thick leucosome layer. The restite and leucosome layers were separately analyzed in this study. 


\section{CHAPTER 4}

\section{METHODS}

\subsection{Monazite U-Th-Pb Geochronology Methods}

In-situ monazite electron microprobe geochronologic data has been used to place constraints on the timing of anatexis and fabric formation in the Eastern Adirondack Mountains (Williams et. al., 2006; Williams et. al., 2017). The oriented samples were cut parallel to lineation and perpendicular to foliation. In this study, multiple polished microprobe sections were made from each sample to characterize the discrete layers in the rock. The entire thin sections were compositionally mapped for $\mathrm{Mg}, \mathrm{K}, \mathrm{Ca}, \mathrm{Ce}$, and $\mathrm{Zr}$ in order to observe the distribution of major silicate phases, kinematic indicators, and to locate monazite and zircon grains (Figure 4) (Williams et. al., 2006).

Approximately 25 monazite grains from each polished section were mapped at high resolution to qualitatively show compositional variation of $\mathrm{Y}, \mathrm{Th}, \mathrm{U}, \mathrm{Ca}$ and $\mathrm{Si}$ to delineate distinct compositional domains. The compositional grain maps were simultaneously processed to compare the intensity of element abundances in each domain across all of the grains. All of the monazite grain maps were placed around the fullsection map in Adobe Illustrator to characterize the monazite setting and to evaluate the textural and zoning significance (see Williams et. al., 2006) (Figure 5). The monazite grain maps display an average of three to six compositional domains in a typical thin section (Figure 5). All domains in a single grain were analyzed to show the relative changes in monazite composition, even if the date uncertainties overlapped.

The monazite grains were analyzed on the SX-100 Cameca Ultrachron electron microprobe at the University of Massachusetts Amherst. The Ultrachron microprobe is 
used to make high-precision $\mathrm{U}-\mathrm{Th}-\mathrm{Pb}$ analyses with simultaneous trace and rare earth elements (REEs) analyses. HREE analyzed in this study are Eu, Tb, Dy, Ho, Er, Tm, and Yb. LREE analyzed in this study are La, Ce, Pr, Nd, and Sm. The standard used for consistency in the dating is the Moacir Brazillian pegmatite monazite with a weighted mean ${ }^{207} \mathrm{~Pb} /{ }^{235} \mathrm{U}$ age of 504.3 0.2 Ma $(2 \sigma, \mathrm{MSWD}=0.64)$ (Gasquet et al., 2010; Dumond et al., 2015). The analytical methods for U-Th-total Pb, domain-specific date and trace element analysis are summarized in Williams et. al., 2006 and Dumond et. al., 2008 


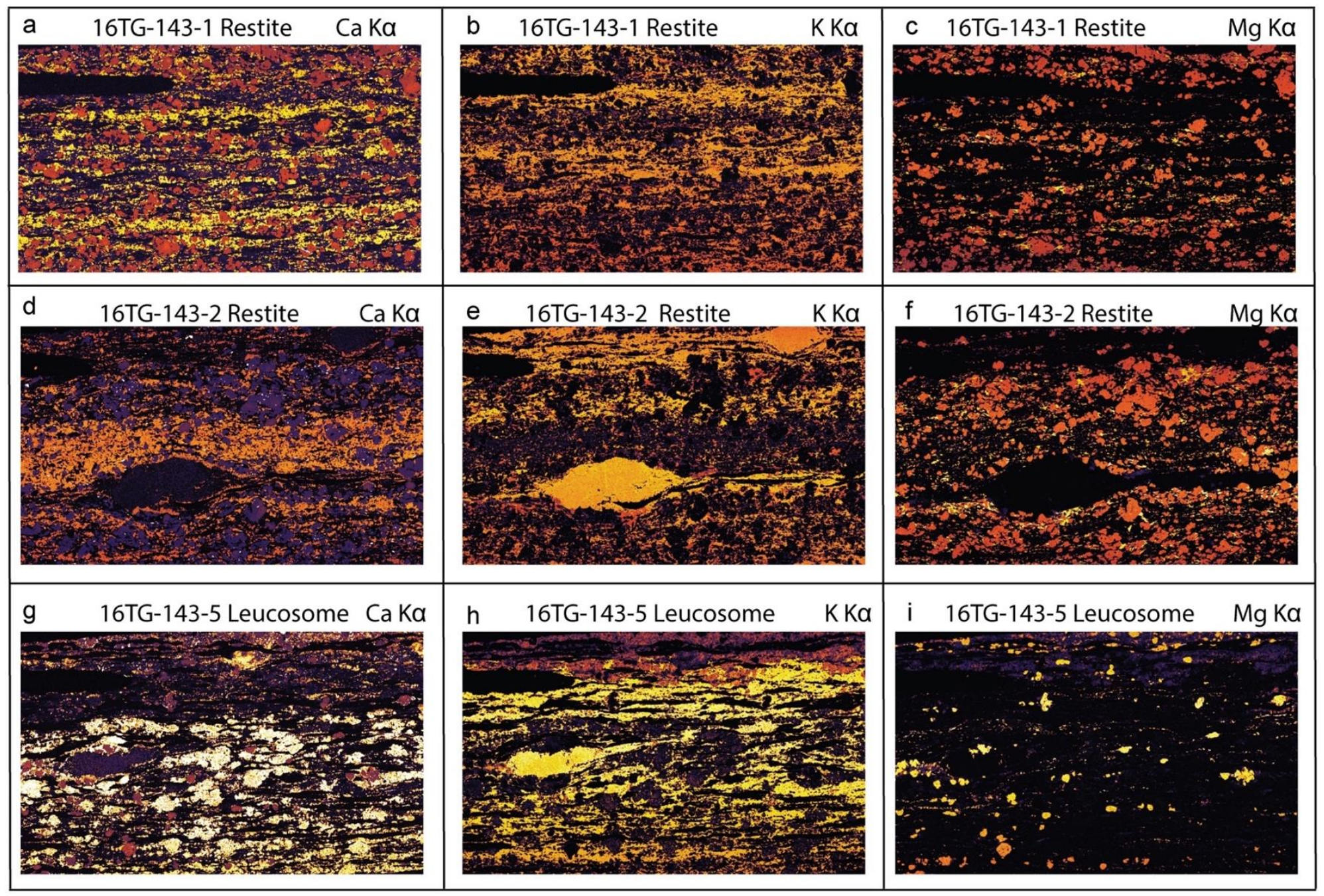

Figure 4: Full section x-ray maps of $\mathrm{Ca}, \mathrm{K}$, and Mg for samples 16-TG-143-1 (restite), 16-TG-143-2 (restite + leucosome), and 16TG-143-5 (leucosome). 


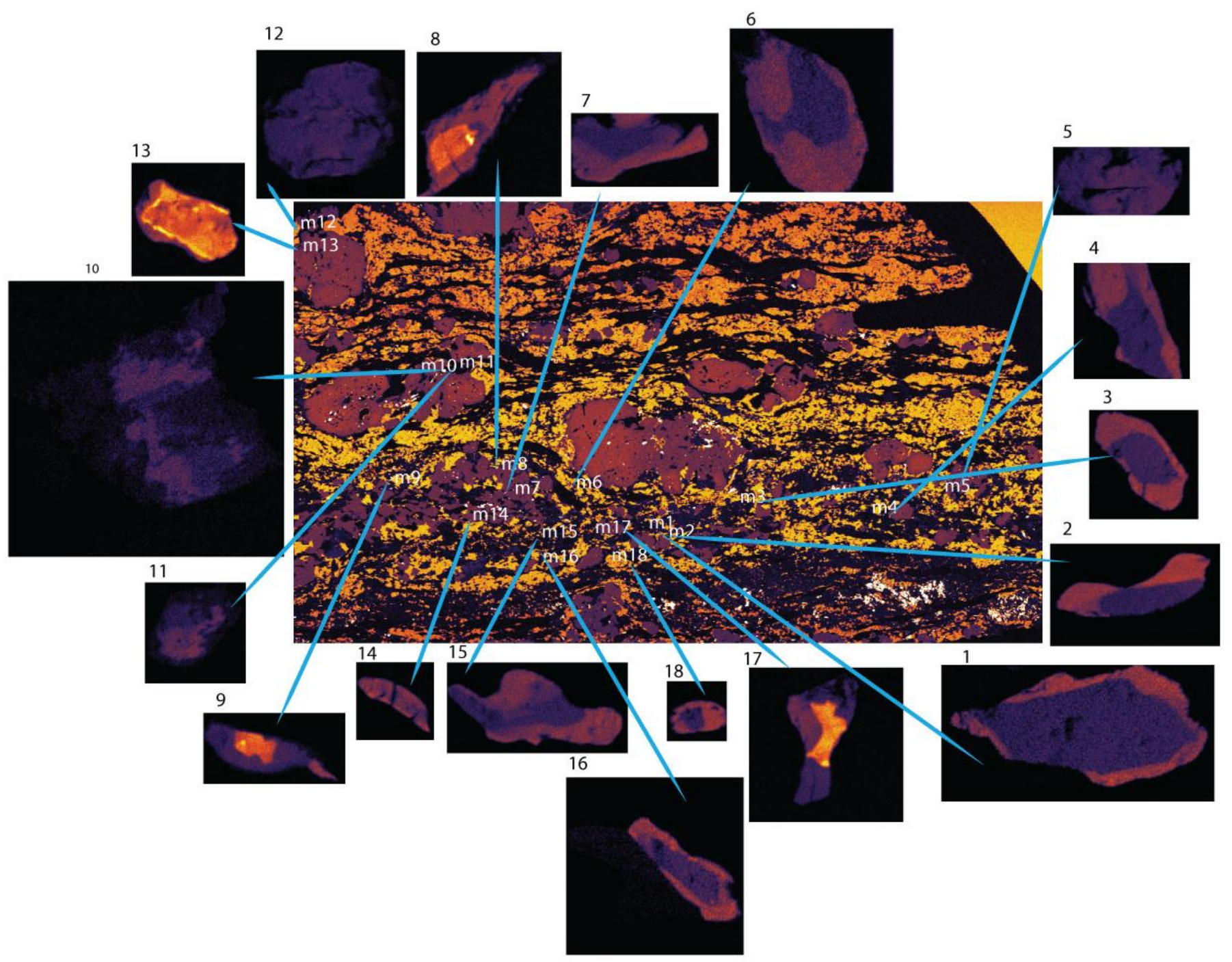

Figure 5: Full-section map (16-TG-144) with arrows connecting monazite grain maps to the monazite location in the thin section in order to evaluate the textural and zoning significance. 


\subsection{Zircon U-Pb Geochronology Methods}

Zircon grains were dated at the University of Arizona LaserChron laboratory using a Thermo Element2 single-collector laser ablation inductively coupled plasma mass spectrometry (LA-ICPMS) in order to place additional constraints on the timing of anatexis and fabric formation in the eastern Adirondack Mountains. Grains were dated using both in-situ and mounted mineral separate dating techniques. Two restite samples (16TG-143-1+2) and one leucosome sample (16TG-143-5) were dated via the in-situ method. In-situ zircon textures were first characterized using cathodoluminescence (CL) at the University of Massachusetts Amherst in order to evaluate zoning and identify targets based on texture prior to dating. The in-situ zircon analyses were made using a 15 $\mu \mathrm{m}$ spot size. Zircon separates were made at the University of Arizona for the restite (16TG-143-1) and leucosome (16TG-143-2) samples. The zircon grains were first separated from the rock and then grains were hand-picked and mounted in epoxy on a round disk. Low-resolution CL and BSE imaging was used to characterize grains prior to dating. 300 spots were analyzed in the restite and 40 spots were analyzed in the leucosome. Each sample was dated with the goal of collecting dates from core and rim domains from the same grain. Zircon grain mounts were dated using a $20 \mu \mathrm{m}$ spot size. Results with $95 \%$ to $100 \%$ concordance were evaluated, and all other discordant grains were removed from the populations. See Gehrels et al., (2006, 2008) for the Laser Ablation ICP Mass Spectrometry methods at the LaserChron laboratory. 


\section{CHAPTER 5}

\section{RESULTS}

\subsection{Field Observations}

Field observations were made at a road cut along Rt. 22 south of Whitehall, NY at the GPS coordinate of -73.4403 longitude, 43.4656 latitude (Figure 2). This outcrop was previously analyzed in the Wong et al., 2012 study. The rocks are garnet-rich paragneisses with leucosome layers. The leucosome layers were interpreted to represent local anatexis, consistent with the interpretation from Bickford et al., 2008. The outcrops in the study area have a well-developed foliation with a mean strike and dip of $019^{\circ} / 21^{\circ}$. The lineation of the area is defined by aligned sillimanite needles, quartz ribbons, and aligned biotite in the paragneisses. The lineation gently plunges southeast with a mean orientation of $16 \rightarrow 131$. Mesoscopic kinematic indicators are largely absent in the metasedimentary unit, but the region has predominately top-to-the-southeast (normal) shear sense based on asymmetric tails on the $\sigma$-type, K-feldspar and garnet porphyroclasts in the nearby granitic gneiss units (Wong et al., 2012).

\subsection{Restite Monazite Results}

Monazite grains from three restite thin sections were analyzed for a $\mathrm{U} / \mathrm{Pb}$ date and trace elements via EMPA. Restite monazite grains range from 5-80 $\mu \mathrm{m}$ in size and commonly have two or three domains defined by distinct differences in yttrium concentration (Figure 6). Restite yttrium compositional domains are categorized as: 1) high-Y 2) low-Y and 3) rim. High-Y monazite domains are found as small inclusions $(10-20 \mu \mathrm{m})$ in garnet, and less commonly in matrix grains as small, anhedral cores inside 
a low-Y domain. Monazite grains with a high-Y core domain account for approximately one third of all grains. Low-Y domain is only present in the matrix and is the most abundant domain. The domain is approximately $30-80 \mu \mathrm{m}$ in size and commonly has an elongated shape parallel with the foliation. A thin $(2-5 \mu \mathrm{m}$ thick $)$ rim with higher $\mathrm{Y}$ surrounds nearly all the matrix grains.

The monazite dates from each compositional domain type are consistent across the three restite thin-sections. The six monazite populations that resulted from the restite monazite analyses include: $1178 \pm 16,1139 \pm 4,1064 \pm 6,1049 \pm 4,1030 \pm 5$, and 1004 \pm 10 Ma. Sixteen high-Y core domain dates range from 1222 to 1148 Ma. Thirty-eight low-Y domain dates range from 1080 to 1049 Ma. Nineteen high-Y rim domain dates range from 1051 to $978 \mathrm{Ma}$. The results are presented in Figure 7. Each probability distribution represents one monazite date, obtained from one compositional domain. The color codes show the main domain types (i.e. high-Y, low-Y, rim). Typical uncertainties $(1 \sigma)$ range from ca. 4 m.y. to $10 \mathrm{~m} . \mathrm{y}$. , and are rarely greater than $20 \mathrm{~m} . \mathrm{y}$. See appendix A for a complete table of the results. 

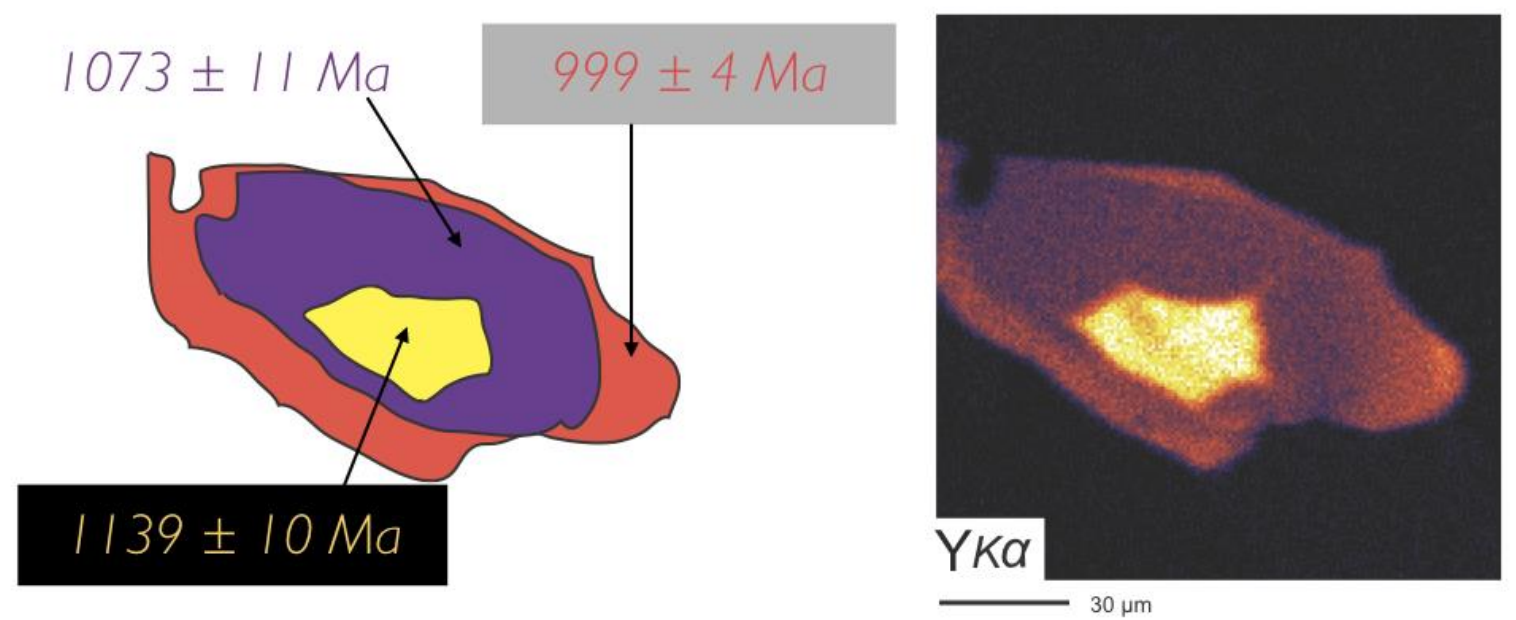

Figure 6: Schematic and yttrium x-ray map showing the three compositional zones and associated dates for a monazite grain in the restite.
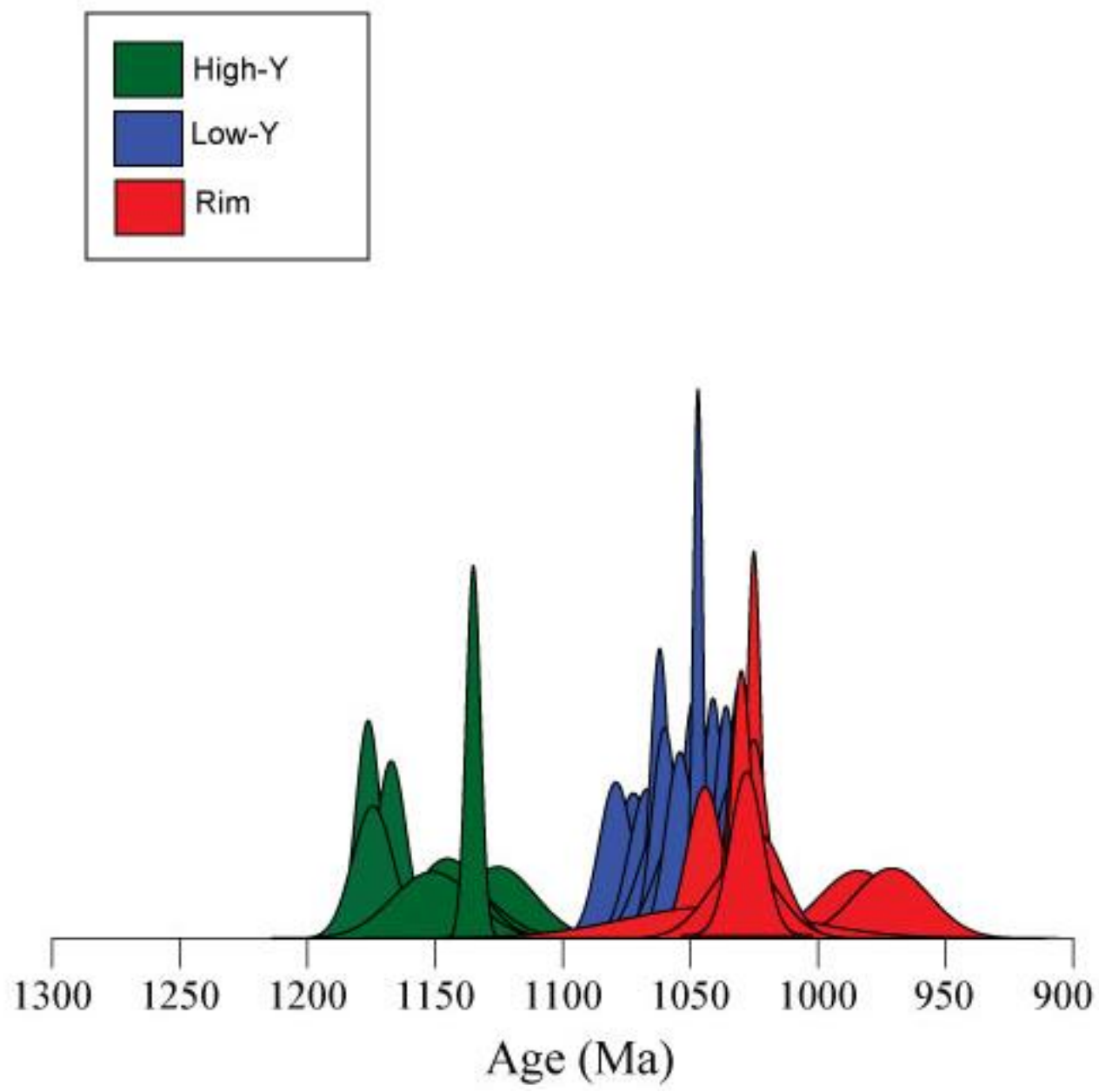

Figure 7: Monazite date results from the restite layer. Green histograms are the inner core domain with high-Y, blue histograms are the outer core domains with low-Y, and red histograms are the rim domains. 


\subsection{Restite Monazite Composition-Date Relationships}

Figure 8 shows the composition of Y, HREE, U, Ca, Th in restite monazite grains. Arrows connect core and rims from single monazite grains to demonstrate the relative compositional changes over time, even if the calculated uncertainties overlap. In general, the high-Y core domain has higher Y, U, HREE but lower Ca and Th compared to the low-Y domain. 

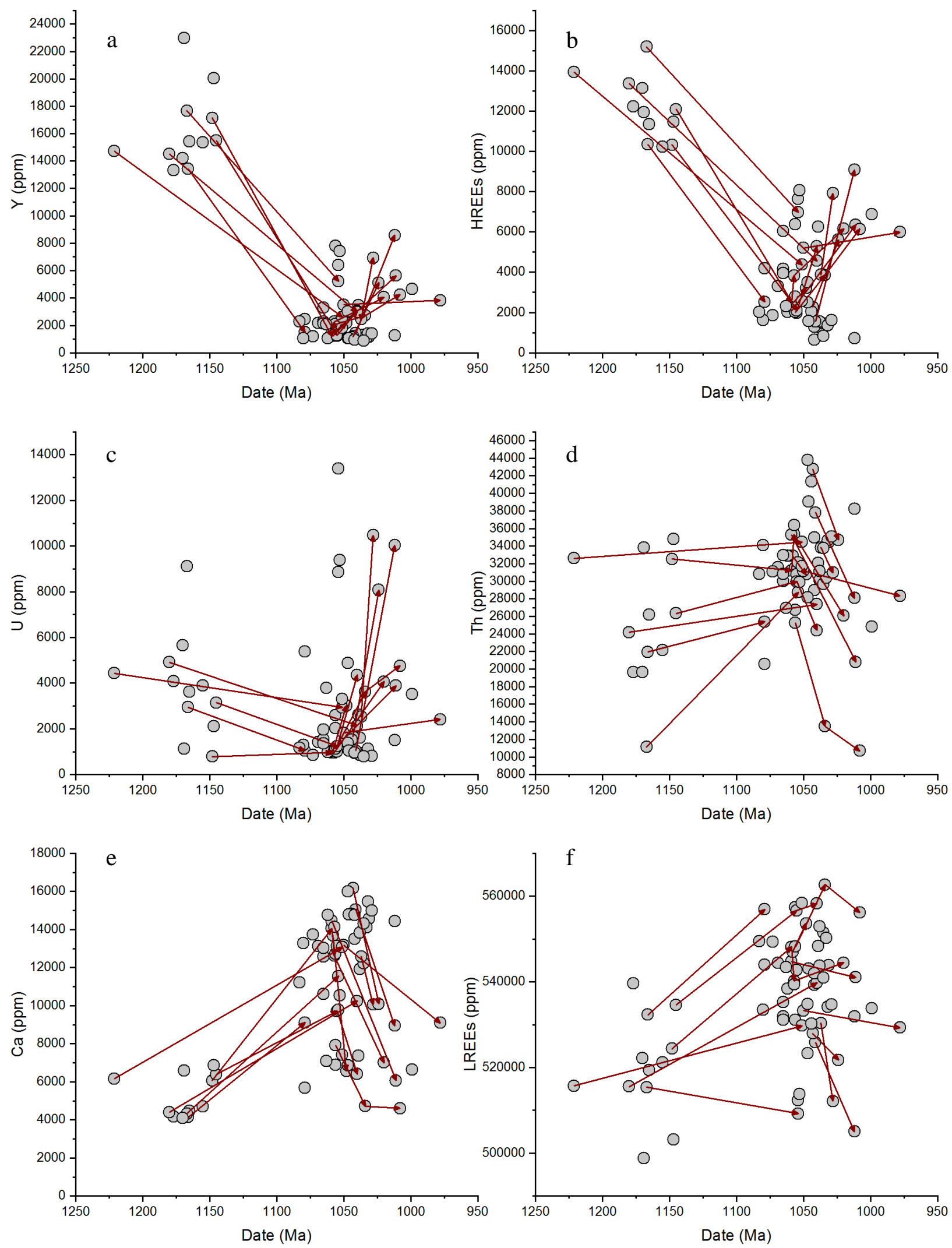

Figure 8: Restite monazite composition vs calculated date. Arrows connect cores to rims of the same grain. 


\subsection{Leucosome Monazite Results}

Monazite grains in the $3 \mathrm{~cm}$ leucosome layer (Figure 3) are distinctly different from the restite monazite grains within the same rock. The most obvious difference is that there are only 13 grains in the layer compared to over 50 grains in the restite. There is no monazite included in garnet. Based on high resolution compositional maps, yttrium domains are irregular, anhedral, and patchy (Figure 9). The leucosome monazite domains are also distinguished by distinct differences in yttrium concentrations and are similarly categorized as: 1) high-Y 2) low-Y and 3) rim. The high-Y domain is present as small (2-10 $\mu \mathrm{m})$, anhedral domains located in the center or near an edge of a lower-Y grain. The low-Y domain ranges from 10-100 $\mu \mathrm{m}$ and has a heterogeneous, patchy texture with irregular edges. Some, but not all, of the grains are surrounded by a thin rim with a higher Y concentration. Backscatter (BSE) scanning electron microscope (SEM) images reveal that apatite and uranothorite inclusions surround the edge of nearly all monazite grains (Figure 9c). The location of apatite around the edges of the monazite grain is clearly defined in the calcium compositional map (Figure 9d).

The calculated dates for the three domains are all younger than ca. 1065 Ma. The two high-Y domain dates are $1062 \pm 9$ and $1048 \pm 9$ Ma. Th high-Y domains have a date that is younger than the date of the low-Y domain in the same grain, a relationship that is opposite from the relationship in the restite grains. Seven low-Y domains range from 1067 to $1048 \mathrm{Ma}$. The two rim domain dates are $1049 \pm 4$ and $1030 \pm 16 \mathrm{Ma}$. The results are presented in Figure 10. Each probability distribution represents one monazite date, obtained from one compositional domain. The color codes show the main domain types 
(i.e. high-Y, low-Y, rim). Typical uncertainties $(1 \sigma)$ range from ca. 4 m.y. to 10 m.y., and rarely greater than 20 m.y.

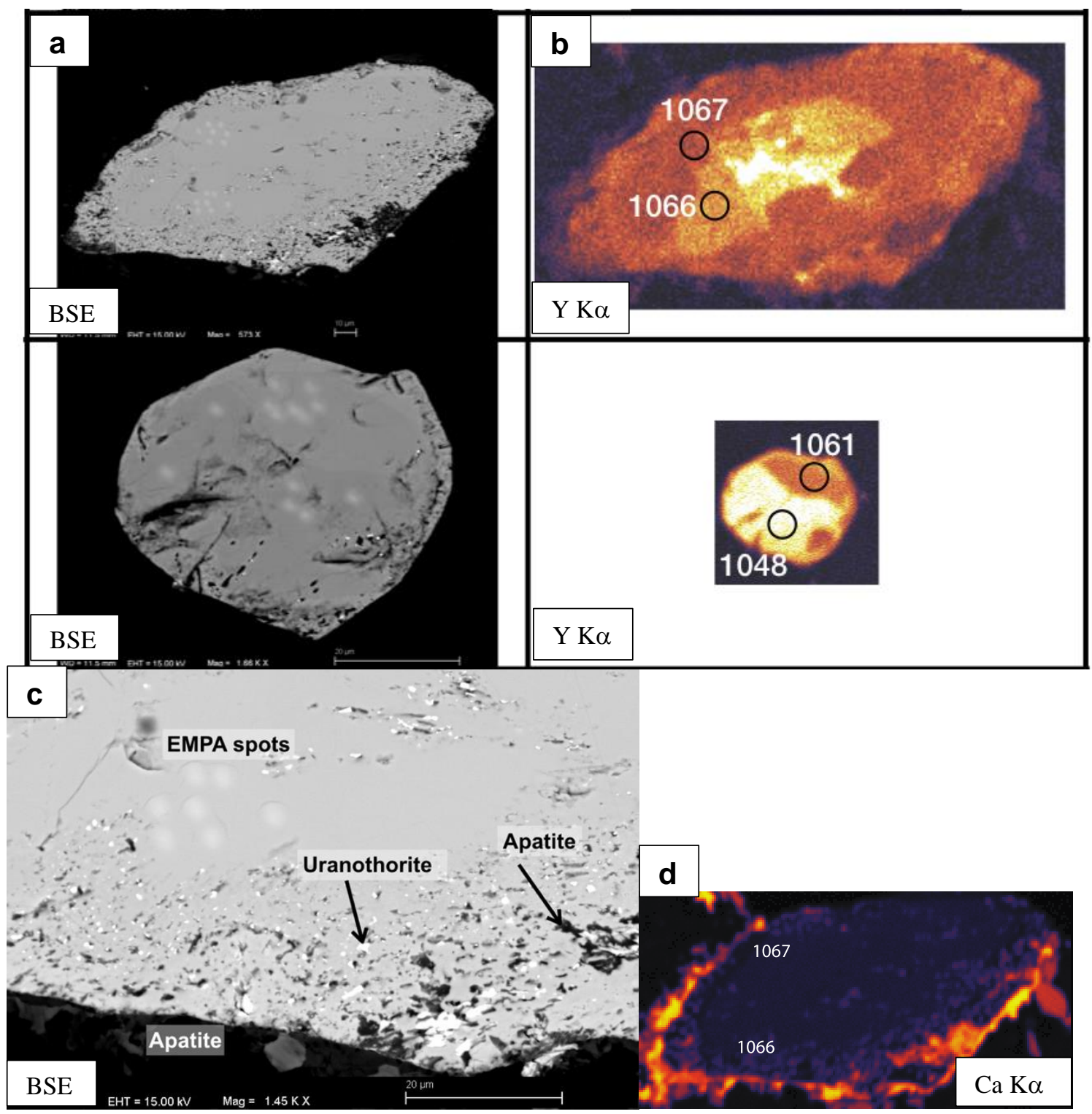

Figure 9: A) BSE images of the leucosome (16TG-143-5) monazite with uranothorite inclusions and alteration to apatite on the edges. B) Yttrium electron microprobe $\mathrm{x}$-ray map showing the compositional zoning and associate date for the leucosome layer monazite grains. C) Close up of alteration texture including uranothorite and apatite alteration textures D) Calcium $x$ ray map showing apatite alteration on monazite edge 


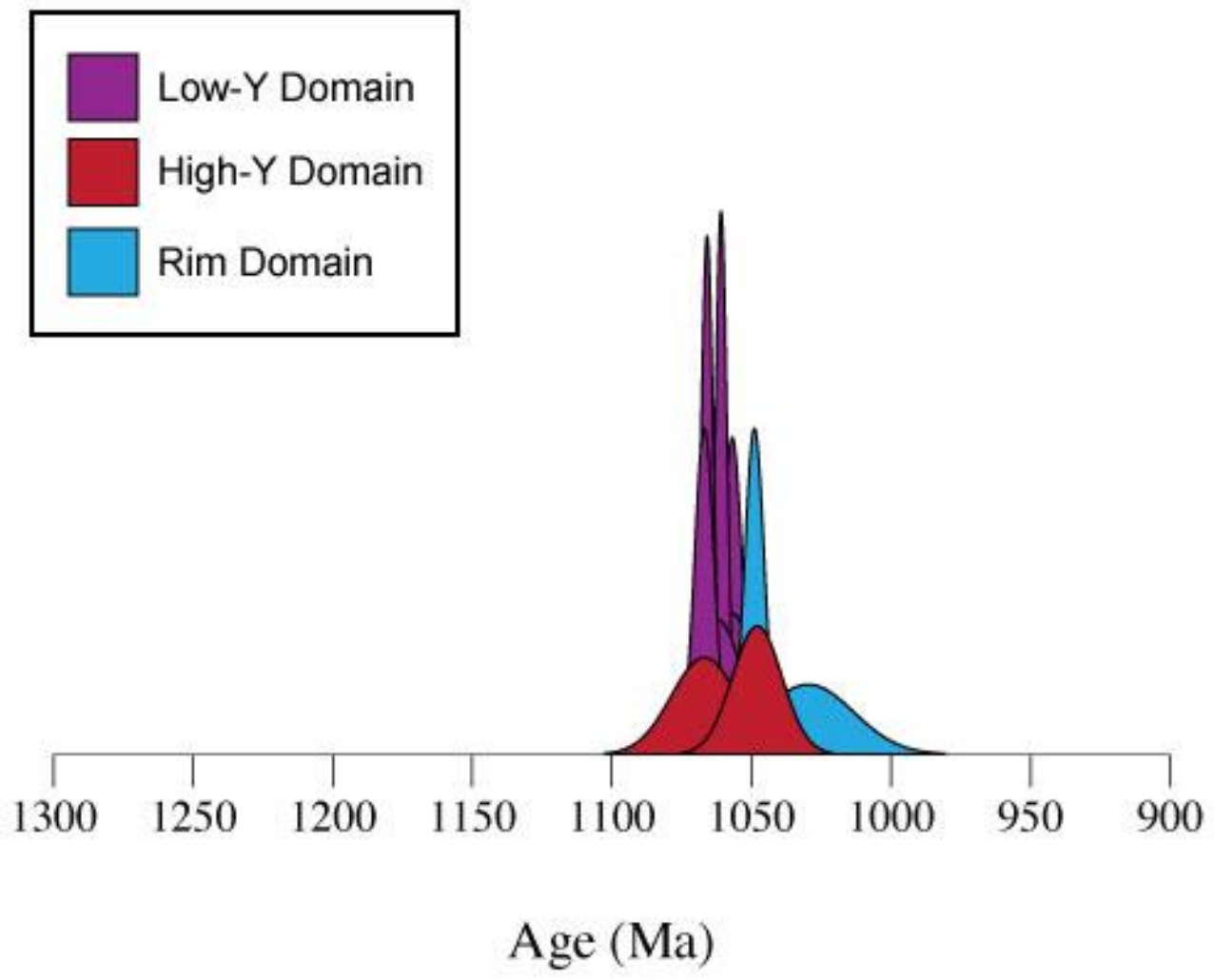

Figure 10: Monazite date results from the leucosome layer. Purple histograms are the low-Y domains, blue histograms are the high-Y domains, and red histograms are the rim domains. There are no monazite grains older than $1067 \mathrm{Ma}$.

\subsection{Leucosome and Restite Monazite Composition Comparison}

Figure 11 shows the comparison of Y, HREE, U, Th, Ca, LREEs in the restite and leucosome monazite grains. The leucosome does not have dates older than $1067 \mathrm{Ma}$. Compared to the restite, the leucosome has a higher content of $\mathrm{Th}$ and $\mathrm{Ca}$, a lower content of LREEs, and a comparable content of Y, HREE and U at ca. $1050 \mathrm{Ma}$. 

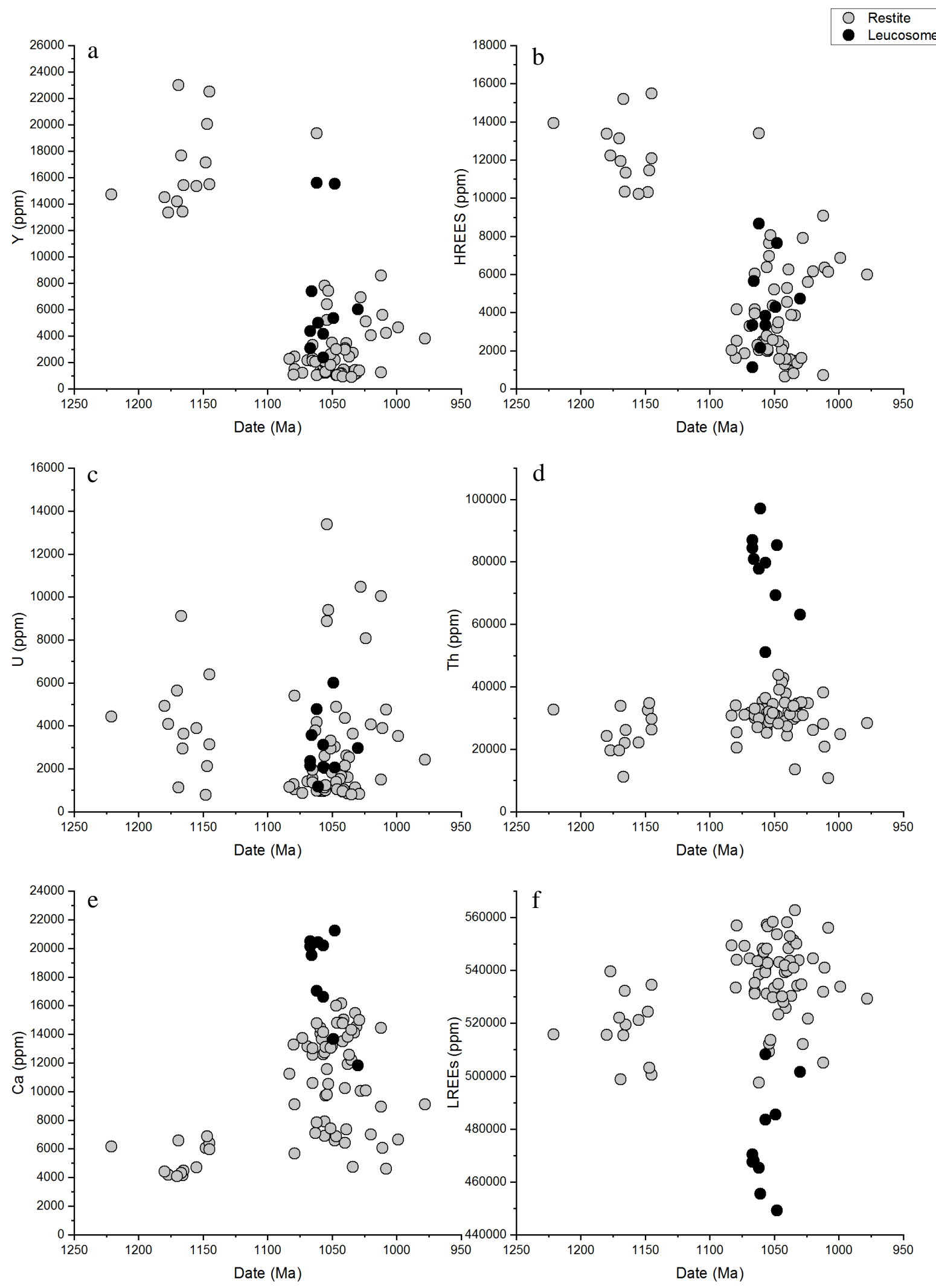

Figure 11: Comparison of the restite and leucosome monazite compositions for Y, HREE, $\mathrm{U}, \mathrm{LREE}$, Th and $\mathrm{Ca}$ against calculated date. 


\subsection{In-situ Restite Zircon Results}

Zircon textures in cathodoluminescence (CL) are commonly indicative of the environment from which the grain grew (Pidgeon et al., 2000; Hermann and Rubatto, 2003; Rubatto et al., 2009; Rubatto, 2017), and therefore provide a basis to subdivide different populations. The zircon grains from the in-situ restite samples have three distinct textures in CL: 1) dark CL with oscillatory zoning; 2) fir-tree sector zoning texture (Raven and Dickson, 1989); 3) bright CL with no visible zoning (Figure 12a). Firtree sector zoning texture is characterized as sector zoning with a distinct zigzag boundary (Raven and Dickson, 1989). Dark CL and oscillatory zoning texture are typically present as small cores $(\sim 10-20 \mu \mathrm{m})$ within larger grains. Fir-tree sector zoning is a predominate population in the restite and commonly surrounds the CL dark cores. Firtree grains are typically round in shape with sizes ranging from $\sim 30$ to $60 \mu \mathrm{m}$. Bright CL texture is present primarily as rims, but also as large domains around cores. Bright CL domain ranges in size from $\sim 2$ to $60 \mu \mathrm{m}$. The three main textures were targeted for insitu dating. Results are presented below (Figure 12b). See appendix B for a complete table of the results.

1) Dark CL, oscillatory cores yield ${ }^{207} \mathrm{~Pb} /{ }^{206} \mathrm{~Pb}$ dates of 1188 - $1135 \mathrm{Ma}$, with a weighted mean of $1162 \pm 25 \mathrm{Ma}(2 \sigma$, mean square of weighted deviates [MSWD]= $0.33, n=6)$. The $\mathrm{U} / \mathrm{Th}$ ratios range from 3.9 to 55.8 with a mean of 16.3 . The $\mathrm{U}$ content ranges from 407 to $768 \mathrm{ppm}$ with a mean of $575 \mathrm{ppm}$.

2) Fir-tree sector zoning textures yield ${ }^{207} \mathrm{~Pb} /{ }^{206} \mathrm{~Pb}$ dates of $1064-1019 \mathrm{Ma}$, with a weighted mean of $1049 \pm 14 \mathrm{Ma}(2 \sigma, \mathrm{MSWD}=0.48, n=8)$. The $\mathrm{U} / \mathrm{Th}$ ratios range from 8.8 to 19.5 with a mean of 14.6 . The $\mathrm{U}$ content ranges from 140 to 292 with a 
mean of $187 \mathrm{ppm}$.

3) Bright $\mathrm{CL}$ textures yield ${ }^{207} \mathrm{~Pb} /{ }^{206} \mathrm{~Pb}$ dates of 1053 - $1011 \mathrm{Ma}$, with a weighted mean of $1037 \pm 14 \mathrm{Ma}(2 \sigma, \mathrm{MSWD}=1.7, n=9)$. The $\mathrm{U} / \mathrm{Th}$ ratios range from 9.3 to 203.0 with a mean of 61.3. The $\mathrm{U}$ content ranges from 143 to 468 with a mean of $231 \mathrm{ppm}$.




Figure 12: In-situ zircon results from the restite. A) BSE and CL images of the in-situ restite zircon. The CL reveals three primary textures that were the target for dating: 1) oscillatory zoned cores 2) fir-tree sector zoning textures and 3) bright CL rims. B) Concordia diagram of the in-situ results. There are two populations at 1) $1162 \pm 7 \mathrm{Ma}$ and 2) $1051 \pm 7 \mathrm{Ma}$

\subsection{Separate Restite Zircon Results}

The zircon separate was initially imaged with a low-resolution CL at the University of Arizona. Therefore, domains were dated without careful characterization of textures prior to dating. 300 analyses were placed in the center and edge of grains in an attempt to date the rims and cores of the grains. Zircon textures for the populations were imaged after dating using high-resolution CL at the University of Massachusetts. Zircon grains from the restite separate have two distinct textures in CL: 1) dark CL with oscillatory zoning and 2) fir-tree sector zoning texture (Raven and Dickson, 1989) Results are presented below (Figure 13a):

1) Dark CL, oscillatory zoned core yielded a population at $1206 \pm 8 \mathrm{Ma}(2 \sigma, n=6)$. The dates range from 1286 to $1116 \mathrm{Ma}$. The U/Th ratio ranges from $3.4-24.9$ with a mean of 12.6. The $\mathrm{U}$ content ranges from 239 to $345 \mathrm{ppm}$ with a mean of $275 \mathrm{ppm}$.

2) Fir-tree texture zircon yielded a population at $1046 \pm 2 \mathrm{Ma}(2 \sigma, n=113)$. The dates range from 1088 to $1018 \mathrm{Ma}$. The U/Th ratios range from 10.2 to 341.4 with a mean of 29.9. The $\mathrm{U}$ content ranges from 84 to $441 \mathrm{ppm}$ with a mean of $147 \mathrm{ppm}$.

The dark CL with oscillatory zoning grains are commonly located in the center of larger grains. A majority (95\%) of the zircon grains in the mineral separate have the fir-tree sector zoning texture (Rubatto, 2017) and are very large $(\sim 80-120 \mu \mathrm{m})$ in size (Figure 13b). The U vs. date for the in-situ and separate zircon data shows that the fir-tree sector zoning zircon crystallized from ca. 1070 to 1030 Ma with relatively low U (Figure 14). 


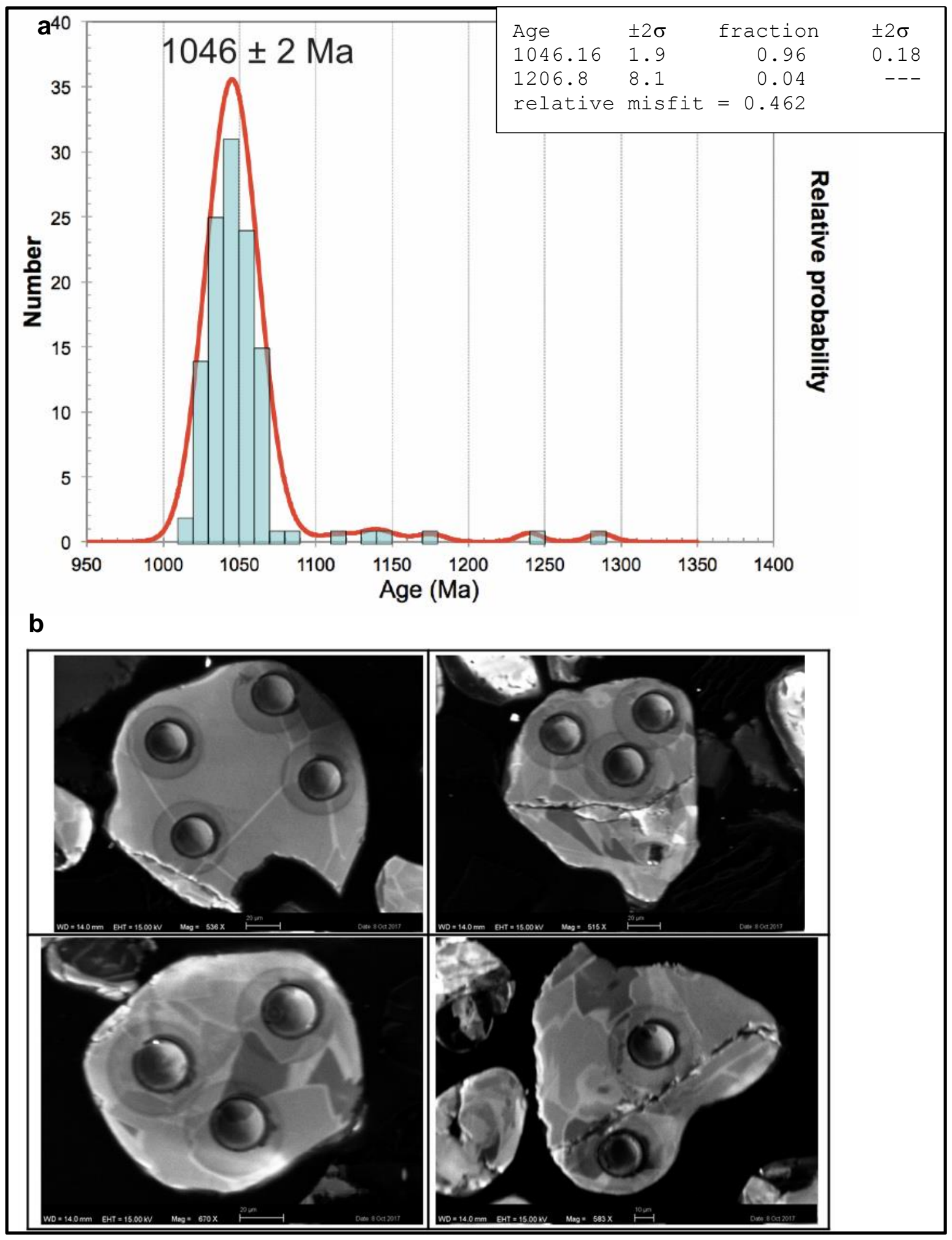

Figure 13: Separate zircon results from the restite. A) The probability density plot shows one population at $1046 \mathrm{Ma}$. The two populations are 1) $1206 \pm 8 \mathrm{Ma}$ and 2) $1046 \pm 2 \mathrm{Ma}$. B) CL images of the separate restite zircon. CL revels that the $1046 \pm 2$ Ma grains have fir-tree sector zoning textures. 


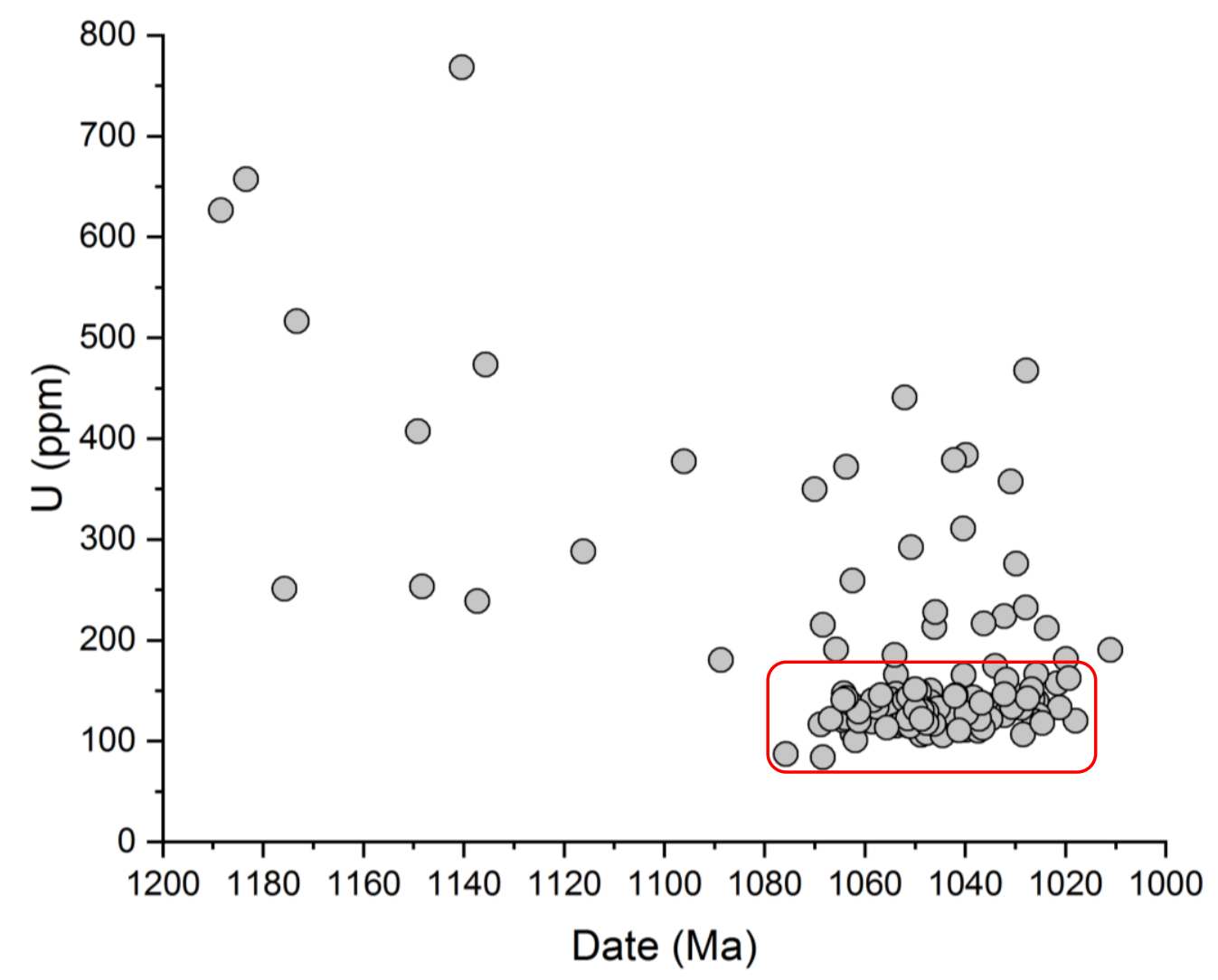

Figure 14: In-situ and separate restite zircon dates plotted against uranium. The highlighted area represents the zircons with the fir-tree sector zoning.

\subsection{In-situ Leucosome Zircon Results}

Zircon from the $3 \mathrm{~cm}$ leucosome layer were analyzed in a polished thin section and also as a separate. Thirty zircon grains in the polished thin section were imaged using high-resolution CL at the University of Massachusetts Amherst. Leucosome zircon grains have three distinct textures in CL: 1) oscillatory zoning; 2) soccer ball texture; 3) bright CL (Figure 15a). The most common texture is oscillatory zoning, present as the core of medium to large $(20-80 \mu \mathrm{m})$ size grains. Only one grain displays a soccer ball texture, a texture suggested to indicate metamorphic growth (Hoskin and Schaltegger, 2003). The zircon rims typically have bright CL, but some also have dark CL rims. Many rim domains are too thin $(2-10 \mu \mathrm{m})$ to date with laser ablation. The three different textures 
were targeted for dating (Figure 15b).

1) Oscillatory zoned grains yielded ${ }^{207} \mathrm{~Pb} /{ }^{206} \mathrm{~Pb}$ dates of $1167-1110 \mathrm{Ma}$, with a weighted mean age of $1151 \pm 27 \mathrm{Ma}(2 \sigma, \mathrm{MSWD}=1.2, n=5) . \mathrm{U} / \mathrm{Th}$ ratios range from 1.5 to 5.8 with a mean of 2.8. The uranium content ranges from 339 to 1009 with a mean of $612 \mathrm{ppm}$.

2) The soccer ball texture yielded $\mathrm{a}^{207} \mathrm{~Pb} /{ }^{206} \mathrm{~Pb}$ date of $1031 \pm 18 \mathrm{Ma}$. The U/Th ratio is 7.9. The $U$ content is $217 \mathrm{ppm}$.

3) Bright $\mathrm{CL}$ domain yielded a ${ }^{207} \mathrm{~Pb} /{ }^{206} \mathrm{~Pb}$ date of $1030 \pm 22 \mathrm{Ma}$. The $\mathrm{U} / \mathrm{Th}$ ratio is 49.1. The U content is $330 \mathrm{ppm}$. 


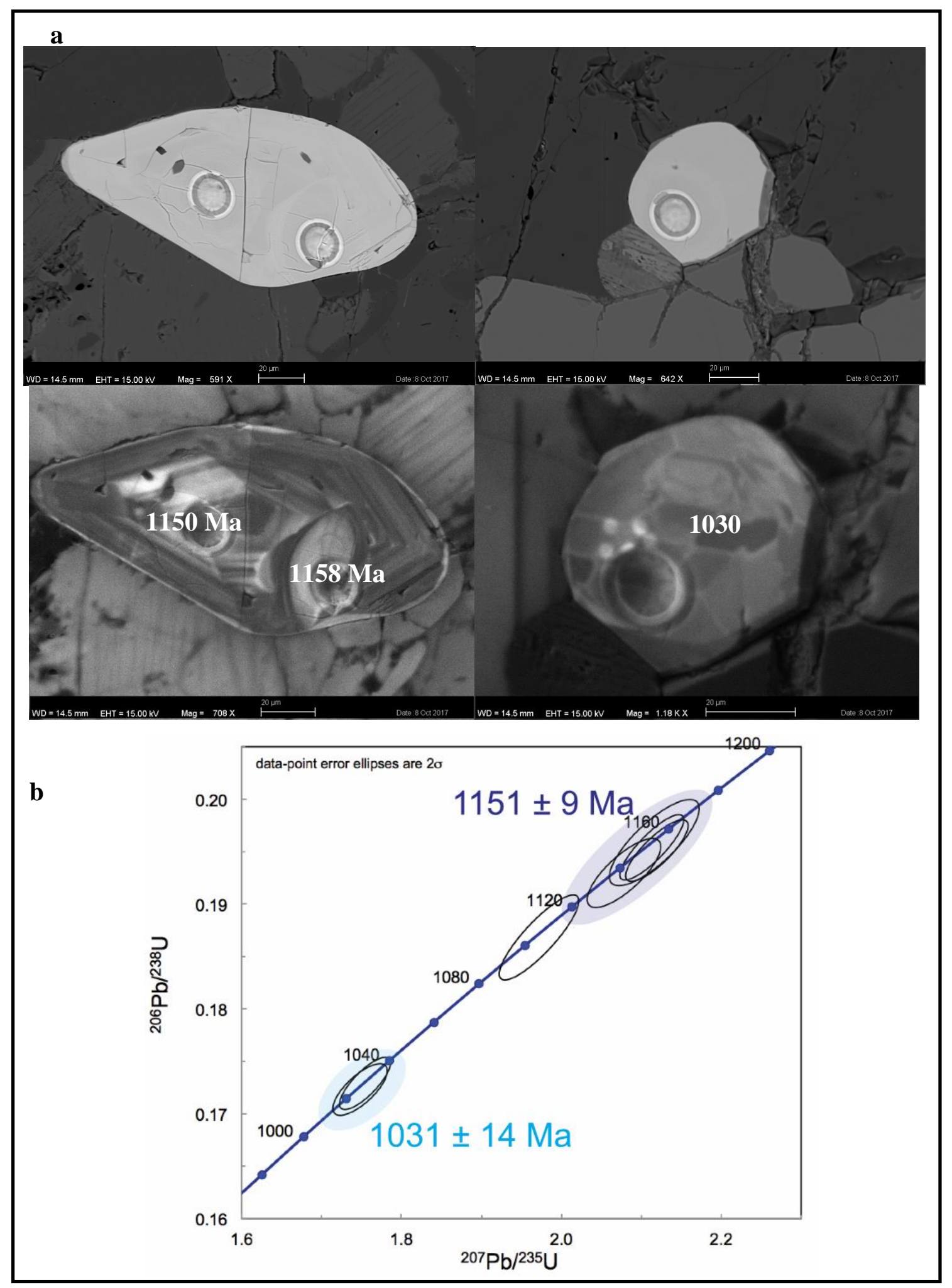

Figure 15: Results from the in-situ leucosome zircon analysis. A) BSE and CL photos of representative zircon textures. The most common texture is an ca. $1150 \mathrm{Ma}$ oscillatory zone grain with a thin CL bright rim. Soccer ball zoning is present in the ca. 1030 grain. B) Concordia diagram showing the two populations at $1151 \pm 9 \mathrm{Ma}$ and $1031 \pm 14 \mathrm{Ma}$. 


\subsection{Leucosome Separate Zircon Results}

The leucosome zircon separate was dated with 40 spot analyses. Cores and rims were targeted for dating. Zircon grains are very large (up to $300 \mu \mathrm{m}$ ). All analyzed grains were characterized after dating using high-resolution CL at the University of Massachusetts Amherst. Zircon grains from the leucosome separate have two distinct textures in CL: 1) dark CL cores with oscillatory zoning and 2) Rims with bright CL. Results are presented below (Figure 16a):

1) Dark CL with oscillatory zoning cores yielded a population at $1163 \pm 6 \mathrm{Ma}$ ${ }^{207} \mathrm{~Pb} /{ }^{206} \mathrm{~Pb}(2 \sigma, n=12)$. The dates range from $1202-1117 \mathrm{Ma}$. The U/Th ratio ranges from $2.0-6.0$ with a mean of 2.8. The $U$ content ranges from 471 to 1674 with a mean of $939 \mathrm{ppm}$.

2) Rims with bright CL yielded a population at $1050 \pm 13 \mathrm{Ma}{ }^{207} \mathrm{~Pb} /{ }^{206} \mathrm{~Pb}(2 \sigma, n=2)$. The two dates are $1050 \mathrm{Ma}$. The $\mathrm{U} / \mathrm{Th}$ ratios are 7.7 and 8.1 . The $\mathrm{U}$ is $452 \mathrm{ppm}$ for the two dates. Many rims were too small to date, but a few rims were as large as 20 $\mu \mathrm{m}$ (Figure 16b). 


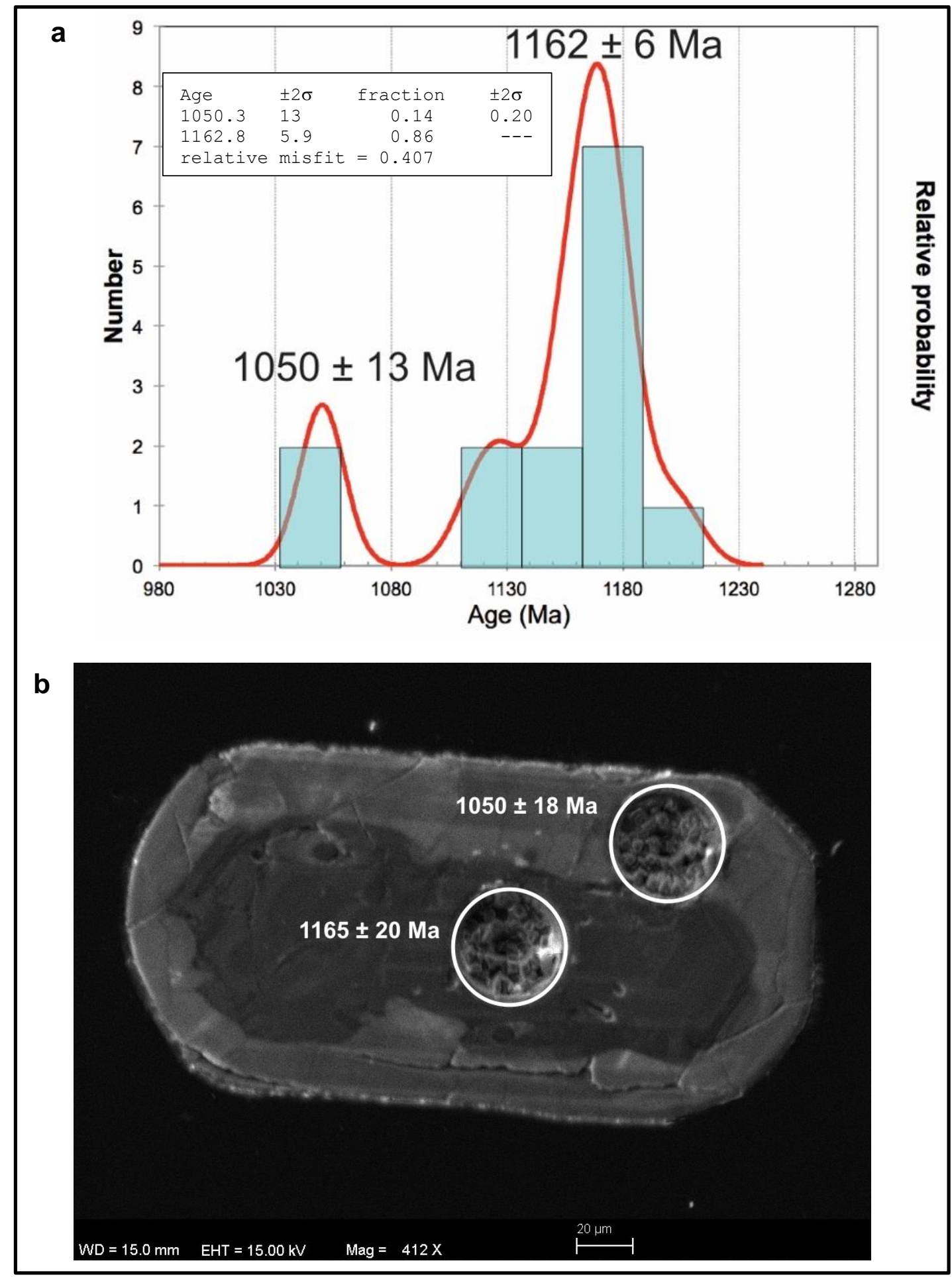

Figure 16: Results from the leucosome separate zircon analysis. A) Population density plot with two major populations at $1162 \pm 6 \mathrm{Ma}$ and $1050 \pm 13 \mathrm{Ma}$. B) CL image of a representative grain from the separate. The grain has a large, $1165 \mathrm{Ma}$ core with a $20 \mu \mathrm{m}$ 1050 Ma rim. 


\subsection{Restite and Leucosome Zircon Comparison}

$\mathrm{Th} / \mathrm{U}$ vs. calculated date for the restite and leucosome zircon grains are plotted to observe zircon heterogeneities between the layers (Figure 17). Leucosome zircon grains constitute a majority of the older, ca. 1150 Ma population and commonly have a $\mathrm{Th} / \mathrm{U}$ above 0.1. Restite zircon grains make up most of the younger, ca. $1050 \mathrm{Ma}$, population and commonly have a $\mathrm{Th} / \mathrm{U}$ below 0.1 . Many grains in the ca. 1150 population have oscillatory zoning, while grains in the younger (ca. 1050) population typically display firtree sector zoning.

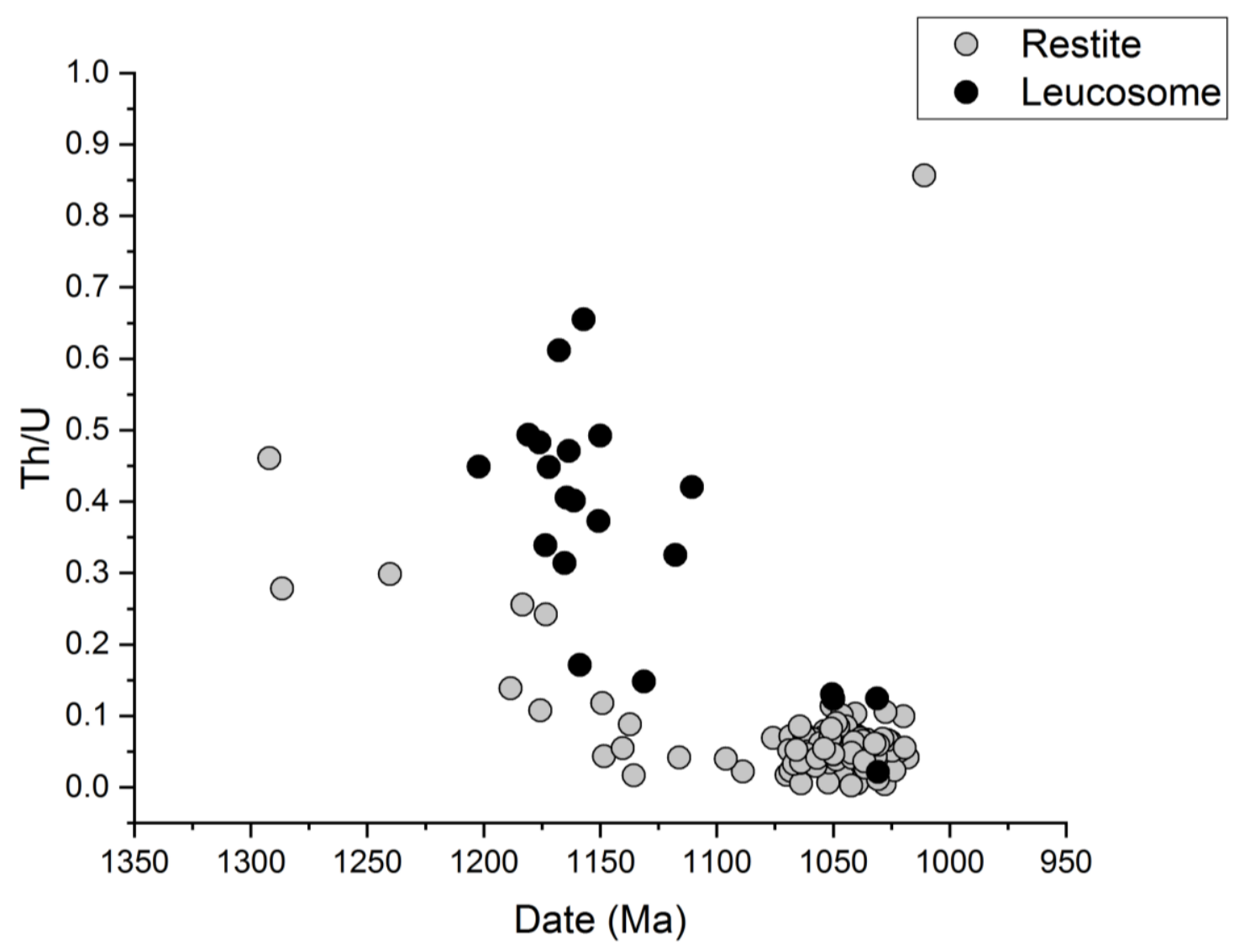

Figure 17: Th/U vs. Date for the leucosome and restite zircon grains from both in-situ and separate analyses. The leucosome grains are primarily ca. $1150 \mathrm{Ma}$ in age with a $\mathrm{Th} / \mathrm{U}$ above 0.1 while the restite grains are primarily ca. $1050 \mathrm{Ma}$ in age with a Th/U below 0.1 . 


\subsection{Thin Section Scale Compositional Comparison}

Distinct compositional (gneissic) layers in the restite have distinctive mineral assemblages and monazite characteristics. We compared the compositional layers restitic thin-section 16TG-143-1. The discrete layers have either predominately K-feldspar-rich or a plagioclase-rich matrix (Figure 18a). The K-feldspar-rich layer is characterized as having small, euhedral garnet, little or no sillimanite or biotite, and little or no monazite (Figure 18b). The plagioclase-rich layer has abundant, large, anhedral garnet, biotite, sillimanite and abundant monazite grains (Figure 18c). Biotite is present around garnet in the plagioclase-rich layer (Figure 18c). The monazite grains from each layer were compared to see if there are differences between the layers.

Figure 19 shows the comparison of $\mathrm{Y}, \mathrm{HREE}, \mathrm{LREE}, \mathrm{U}, \mathrm{Ca}$, Th content in the monazite from the K-feldspar-rich and plagioclase-rich layer. In general, the monazite in the K-feldspar-rich layer has higher Y, U, HREE, lower LREE, and comparable Ca and Th. 


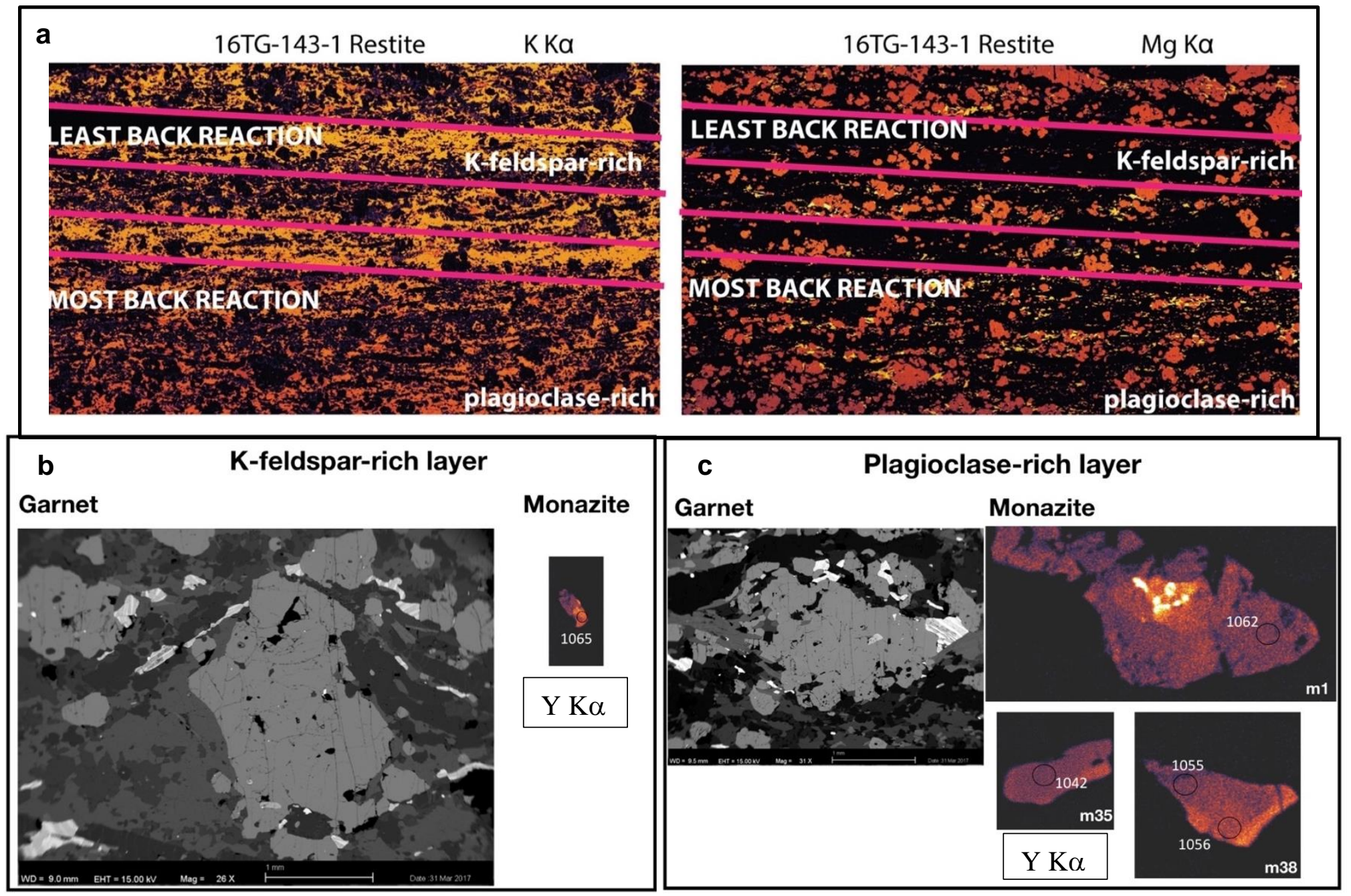

Figure 18: A) Magnesium and potassium x-ray maps of 16-TG-143-1 with lines delineating the layers in the thin section that are inferred to have retained melt (plagioclase-rich) and lost melt (K-feldspar-rich). B) BSE image of garnet and Y maps of monazite in the K-feldspar-rich layer Note: Monazite grain 16TG-143-m43 was not yet mapped. C) Garnet and Y maps of monazite in the plagioclase-rich layer 

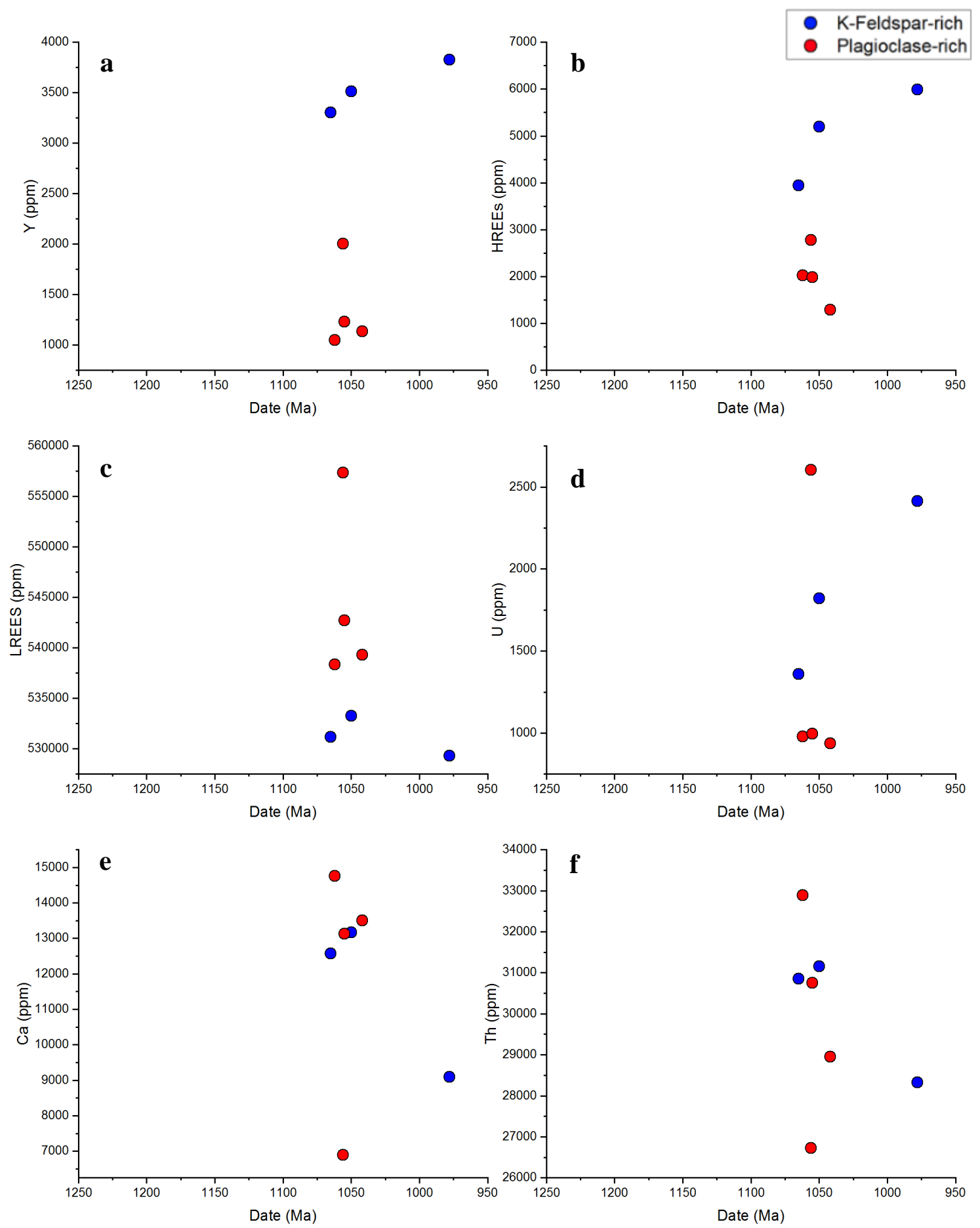

Figure 19: Comparison of monazite composition vs date between the K-feldspar and plagioclase-rich layers. 


\section{CHAPTER 6 \\ DISCUSSION}

The (1190-1140 Ma) Shawinigan orogeny and the (1080-1020 Ma) Ottawan orogeny may have both contributed to widespread melting in the Adirondack Mountains (Rivers, 2008; McLelland et al., 2013; Chiarenzelli et al., 2017). One challenge in delineating the timing of melting in the Adirondack Mountains is that both events have been interpreted to have involved granulite facies metamorphism and partial melting (Heumann et al., 2006; Bickford et al., 2008; McLelland et al., 2013). Some studies suggest that melting occurred during the Shawinigan/AMCG event (ca. $1150 \mathrm{Ma}$ ) (Heumann et al. 2006; Williams et al., in review), whereas others suggest further melting in the Ottawan event (ca. $1050 \mathrm{Ma}$ ) (Bickford et al., 2008). In this study, samples were collected from a single outcrop located along Rt. 22 south of Whitehall, NY. Layering in the outcrop is typical of the compositional variation seen in the migmatites of the Adirondack Mountains (Williams et al., in review). The following discussion integrates both in-situ zircon and monazite geochronology to understand the variation in the record of melting in a single outcrop in order to better understand the variation in the Adirondack Mountains in general.

\subsection{Timing of Melting}

Monazite domains from the restite yielded dates in six populations, including two major populations near ca. 1150 and ca. 1050 Ma (Figure 20). The two major monazite populations correlate with the interpreted regional tectonic melt events. However, monazite dates alone do not sufficiently provide a basis for delineating tectonic 
interpretations, and therefore additional data from trace elements is necessary to constrain the timing of melting.

Previous studies suggest that the significant melting in the Adirondack Mountains occurred due to biotite dehydration-melting (Williams et al., in review). Additional melt reactions, such as muscovite dehydration-melting, may have occurred at lower temperatures (Williams et al., in review). The samples collected from Rt. 22 are indicative of melting from a biotite dehydration reaction based on the lack of peak biotite and plagioclase and the abundance of garnet and K-feldspar (Storm and Spear, 2005; Yakumchuk and Brown, 2014; Williams et al., in review). Generally, biotite dehydrationreactions have the form:

$\mathrm{Bt}+\mathrm{Pl}+\mathrm{Als}+\mathrm{Qtz}=\mathrm{Grt}+\mathrm{Kfs}+$ melt

$\mathrm{Bt}+\mathrm{Als}+\mathrm{Qtz}=\mathrm{Grt}+\mathrm{Kfs}+$ melt

Yttrium zoning in monazite has been linked to the timing of garnet growth when no other Y-bearing assemblages are present (Zhu \& O’Nions, 1999; Foster et al., 2002, 2004; Pyle \& Spear, 2003; Gibson et al., 2004; Kohn et al., 2005; Kelly et al., 2006; Dumond et al., 2015; Williams et al., in review). Garnet readily incorporates Y + HREE, and thus monazite is expected to become depleted in $\mathrm{Y}+\mathrm{HREE}$ when it crystallizes during or after garnet growth (Dumond et al., 2015; Williams et al., 2017; Williams et al., in review). Similarly, U zoning in has been linked to melt loss from the system. During partial melting, $\mathrm{U}$ is partitioned from the whole rock into melt, and thus removal of melt decreases the concentration of U in monazite (Stephanov et al., 2012). Variation in trace elements within monazite domains may indicate the timing of growth of garnet and melt loss at Rt. 22. 
Restite monazite grains have two major Y compositional domains: high-Y and low-Y. The (ca. 1050) low-Y monazite domains are depleted in Y + HREE and, to a lesser extent, $\mathrm{U}$ relative to the (ca. $1150 \mathrm{Ma}$ ) high-Y domains. The depletion of $\mathrm{Y}+$ HREE suggests that garnet grew prior to monazite crystallization, because monazite and garnet are the only $\mathrm{Y}+$ HREE bearing phases in the assemblage. $\mathrm{Y}+$ HREE drop in two steps (Figure 8 b,c), suggesting that garnet grew in two steps: 1) growth between ca. 1150 and $1065 \mathrm{Ma}$ and 2) further growth between 1065 and $1050 \mathrm{Ma}$. The absence of low-Y monazite as inclusions in garnet supports a post-garnet interpretation for monazite precipitation between ca. 1150 and ca. $1065 \mathrm{Ma}$; however, it difficult to interpret exactly when the garnet grew within the $\sim 85$ m.y. window. U drops slightly between ca. 1150 and ca. 1065, suggesting that some melt may have been lost from the system prior to ca. $1065 \mathrm{Ma}$.

Evidence for biotite dehydration-melting near ca. $1065 \mathrm{Ma}$ is bolstered by the zircon results from restite layers. Zircon analyses from the restite separate display a unimodal population at $1046 \pm 2 \mathrm{Ma}$ with dates ranging from 1070 to $1020 \mathrm{Ma}$. The entire population is characterized by fir-tree sector zoning textures that have been suggested to be indicative of partial melting (Bickford et al., 2008; Rubatto, 2017). The fir-tree texture data suggests a melt event beginning at ca. $1070 \mathrm{Ma}$. $\mathrm{U}$ is also depleted in the ca. 1050 zircon grains, supporting some melt loss prior to ca. $1070 \mathrm{Ma}$. If significant melting occurred during the Shawinigan orogeny, we expect to find older, preserved firtree sector zoning zircon based on the robustness of zircon in melt (Kelsey et al., 2008), however we do not find any Shawinigan age zircon grains with fir-tree texture. While it is possible that the rock underwent some earlier melting, we suggest that the rock 
underwent biotite dehydration-melting at ca. 1070 Ma during the Ottawan orogeny based on monazite and zircon geochronology, geochemistry, and zircon cathodoluminescence textures.

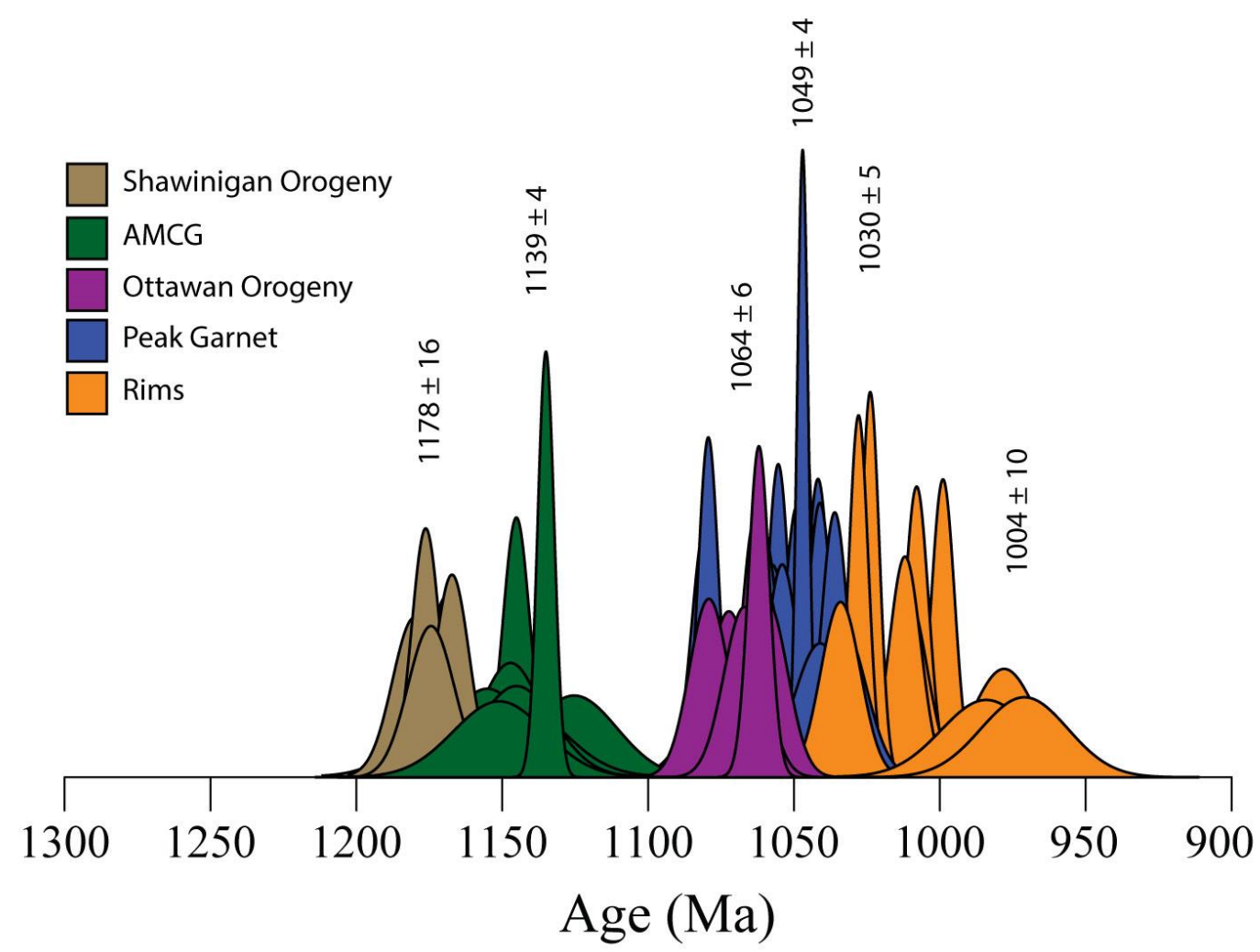

Figure 20: Restite monazite results with the interpreted tectonic event.

\subsection{Timing of Leucosome Production}

Monazite and zircon were also analyzed from a $3 \mathrm{~cm}$ leucosome layer in the rock. The results from the monazite grains show populations at ca. 1050, but no populations at ca. $1150 \mathrm{Ma}$, as in the restite. However, zircon data from the leucosome show a significant population from the cores at ca. $1150 \mathrm{Ma}$, with smaller populations from the rims at ca. $1050 \mathrm{Ma}$. The contradictory geochronology results from the monazite grains 
(ca. 1050) and zircon cores (ca. $1150 \mathrm{Ma}$ ) in the leucosome layer, creates a fundamental challenge for interpreting the timing of leucosome production (Figure 21).

There are two alternative hypotheses, either the leucosome crystallized at ca. 1150 , based on the zircon cores, or at ca. 1050, based on the monazite grains and zircon rims. An additional consideration is whether the leucosome layer originated in the rock or represents a foreign injection. One possibility is that the leucosome was produced in-situ at $1065 \mathrm{Ma}$, consistent with the hypothesized timing of melting from the restite data. Therefore, the monazite dates may represent the timing of leucosome crystallization. The zircon cores may have been inherited from the local rock during the melting, and the zircon rims may represent either the timing of melt crystallization or a subsequent alteration at ca. $1050 \mathrm{Ma}$. The primary concern with this hypothesis is that there is no firtree sector zoning zircon in the leucosome layer. Fir-tree zircon is expected to be inherited in the leucosome at ca. $1065 \mathrm{Ma}$ due to the abundant number of fir-tree grains in the restite. There is evidence for one soccer ball texture zircon at ca. $1030 \mathrm{Ma}$, a texture that may represent metamorphic zircon (Hoskin and Schaltegger, 2003). Alternatively, the leucosome may have originated outside of the rock at ca. $1065 \mathrm{Ma}$, thus inheriting ca. 1150 Ma zircon grains from another source.

The second possibility is that the leucosome was produced at ca. 1150 due to an in-situ melt reaction, such as muscovite dehydration-melting. Th/U less than 0.1 in zircon can be indicative of metamorphic formation while a $\mathrm{Th} / \mathrm{U}$ greater than 0.1 may represent magmatic formation (Rubatto, 2017). Therefore, magmatic $\mathrm{Th} / \mathrm{U}$ signature in the leucosome zircon cores may suggest leucosome crystallization at ca. $1150 \mathrm{Ma}$. The primary concern with this hypothesis is the monazite grains and zircon rims with ca. 1050 
Ma dates. In this hypothesis, monazite grains and zircon rims may represent either remelting of the leucosome or a period of alteration and resetting of the $\mathrm{U}-\mathrm{Pb}$ system associated with events at ca. 1065 Ma and younger (Nasdala et. al., 2002; Williams et al., 2011). Alternatively, it is also possible that the layer originated from outside the rock at ca. 1150 Ma. However, understanding the ca. 1050 Ma age of the monazite grains still poses a challenge when interpreting leucosome production at ca. $1150 \mathrm{Ma}$

A close examination of the leucosome monazite textures reveals intense alteration of the grains. Nearly all of the monazite grains in the leucosome are partly altered to apatite and uranothorite along the edge of the grain. Yttrium compositional x-ray maps show that the texture of the leucosome monazite domains are irregular and heterogeneous, suggesting that the entire grain may have underwent a degree of alteration (Figure 9b). Y is also significantly enriched in certain domains of the monazite grain, but the high-Y domain does not correspond to an older date, as in the restite grains. Similarly, rims surrounding the leucosome zircon grains have an irregular border and the cloudy texture in cathodoluminescence (Rubatto, 2017) (Figure 16b). Fluid alteration in both zircon and monazite has been characterized by partial or full resetting of the $\mathrm{U}-\mathrm{Pb}$ system, formation of uranothorite inclusions, and production of rims (Nasdala et. al., 2002; Geisler et al., 2007; Valley et al., 2011; Williams et al., 2011; Tyson McKinney et al., 2015). Therefore, the monazite grains and zircon rims may represent the timing of fluid alteration, and not melt crystallization.

The leucosome geochronometers have clear evidence for fluid alteration, however there is minimal evidence for alteration to the restite geochronometers (Figure 21). Na and K-rich fluids are suggested to be extremely effective at altering monazite and zircon 
(Valley et al., 2011; Williams et al., 2011). One possibility is that fluids reacted with the leucosome to release $\mathrm{Na}$ or $\mathrm{K}$ that increased the alteration strength of the fluids to preferentially alter the leucosome layer. Alternatively, radiation damage due to the decay of actinides, such as $\mathrm{U}$ and $\mathrm{Th}$, can make a grain more susceptible to alteration as the damage provides a pathway for fluids in the grain (Nasdala et. al., 2002; Karioris et al., 1981; Seydoux-Guillaume et al., 2012). It is possible that the monazite from $1150 \mathrm{Ma}$ accumulated $\sim 85 \mathrm{~m} . \mathrm{y}$. of radiation damage after crystallization, and thus the grains were more prone to alteration at 1050 Ma compared to the newly crystallized restite monazite grains. It is important to note that monazite is rarely present as metamict in nature (Karioris et al., 1981; Seydoux-Guillaume et al., 2012), and thus further research is necessary to understand if these monazite grains accumulated substantial radiation damage. We suggest that the geochronology data suggests that this particular leucosome could have been produced at ca. 1150 or ca. 1065 due to either in-situ melting or inheritance from outside the rock, however alteration processes to the geochronometers must be better understood in order to make a more robust interpretation. 


\section{RESTITE}
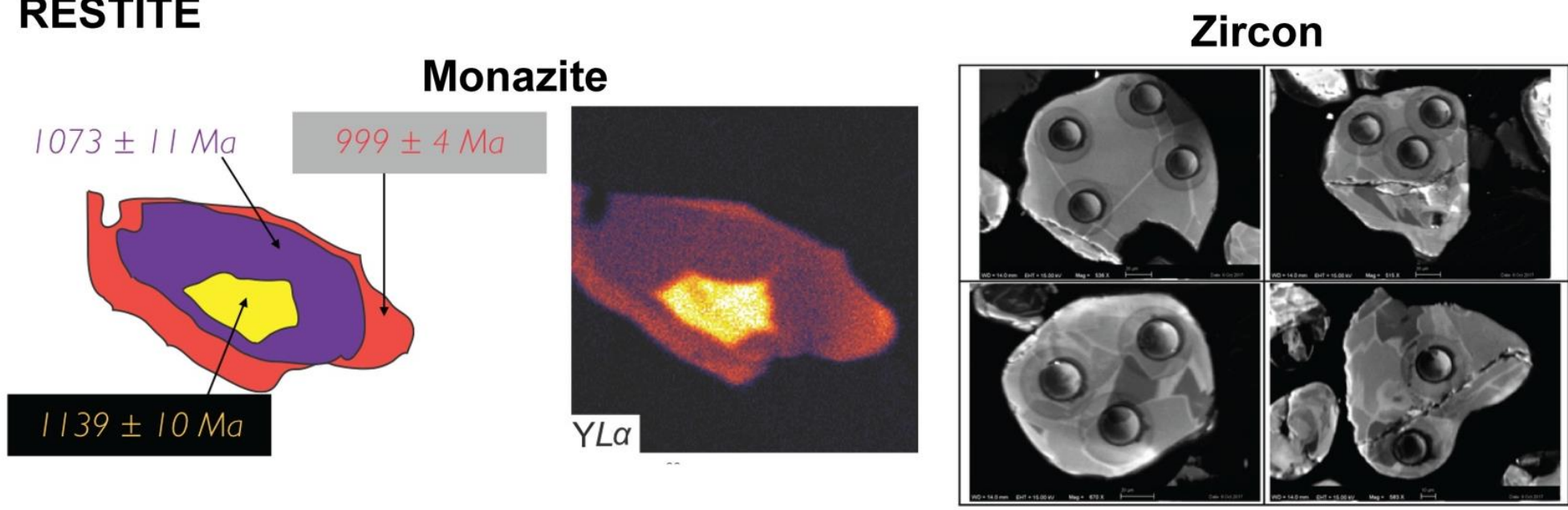

ca. $1050 \mathrm{Ma}$
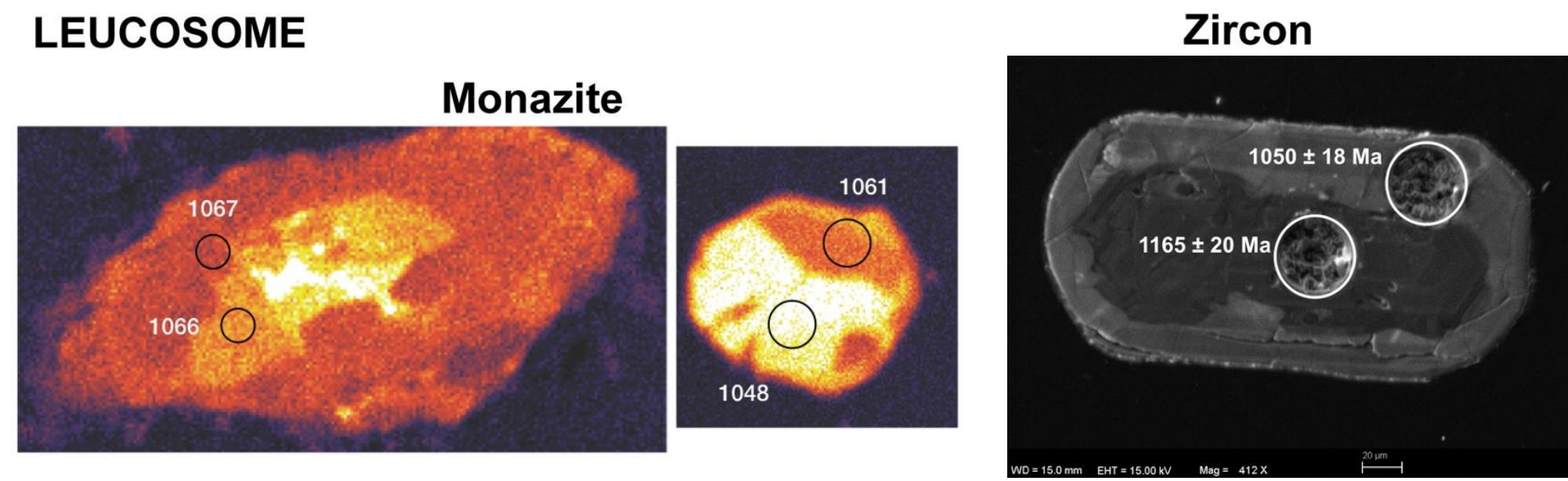

Figure 21: Comparison of the restite and leucosome monazite and zircon grains with associated dates. 


\subsection{Retrograde Metamorphism, Decompression, and Fluid Influx}

Monazite grains examined in this study show evidence for retrograde metamorphism starting at approximately $1050 \mathrm{Ma}$. Monazite rim domains from the restite and leucosome are characterized by a distinct $\mathrm{Y}+$ HREE enrichment (Figure 6). This marked enrichment observed in the rim domain is most consistent with incorporation of Y + HREE due to garnet break down (Dumond et al., 2015; Williams et al., in review). In addition, the monazite rims are characterized by Th depletion after $1050 \mathrm{Ma}$. Fluids, and specifically a dissolution-reprecipitation mechanism, have been shown to effectively remove Th from monazite (Williams et al., 2011). High-Y+HREE and low-Th in the rim domain may represent a period of garnet break down and flux influx after ca. 1050 .

Data from zircon rims provide additional support for fluid influx after ca. 1050 Ma. Zircon in the leucosome and restite have bright CL rim domains marked with depleted U and 1053 - 1011 Ma dates. Previous workers have demonstrated that bright CL domains in zircon may reflect a depletion of trace elements due to fluids rich in chlorine, fluorine or $\mathrm{CO}_{2}$ (Pidgeon et al., 2000; Bickford et al., 2008; Valley et al., 2011), bolstering an interpretation for fluid alteration after $1050 \mathrm{Ma}$. In addition, Pidgeon et al., 2000 suggests that solid state zircon with fir-tree sector zoning can grow in the presence of fluids containing low concentrations of fluorine. One hypothesis is that zircon grains with fir-tree sector zoning were produced due to both anatexis and metamorphic fluid alteration (Pidgeon et al., 2000; Bickford et al., 2008; Rubatto, 2017). Further work to understand the reactions that form zircon with fir-tree texture is needed to clarify this interpretation. In this study, we suggest that zircon rims and fir-tree sector zoning suggest fluid influx from ca. 1050 Ma to ca. $1011 \mathrm{Ma}$. 
Evidence from the monazite and zircon rims have evidence for retrograde metamorphism and fluid influx after ca. $1050 \mathrm{Ma}$. Garnet breakdown was most likely driven by decompression and cooling, and thus the monazite rims may mark the timing of post-orogenic collapse (Williams et al., in review). Wong et al., 2012 previously interpreted the Rt. 22 outcrop to occur within the East Adirondack shear zone. Evidence for syntectonic monazite growth is present as symmetrical, elongated growth in the lineation-parallel ends of the grains found in the matrix (Wong et al., 2012). Fluid influx was likely associated with shearing (Wong et al., 2012). The rim domain is interpreted to represent decompression associated with post-orogenic collapse, shearing and fluid influx after ca. 1050 Ma. A summary timeline is presented in Figure 22. 


\section{Muscovite Dehydration-Melting}

ca. II50 Ma

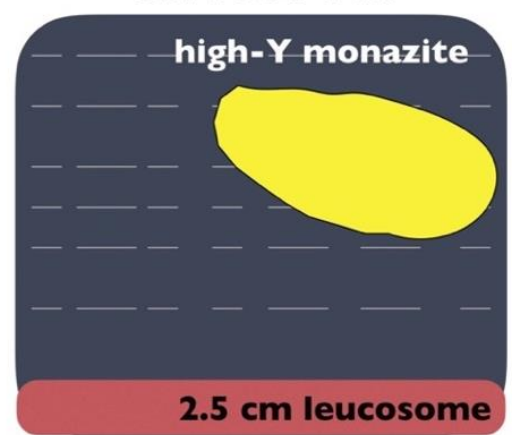

\section{Biotite Dehydration-Melting}

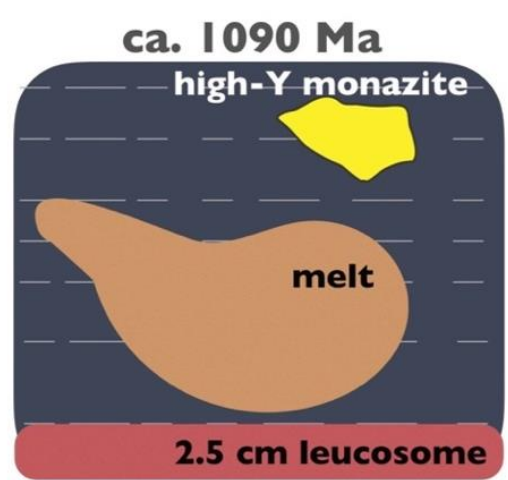

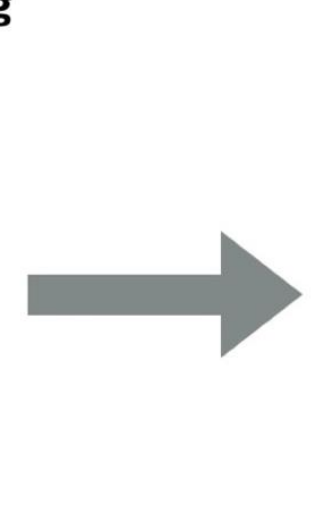

\section{Decompression + Fluid Influx}

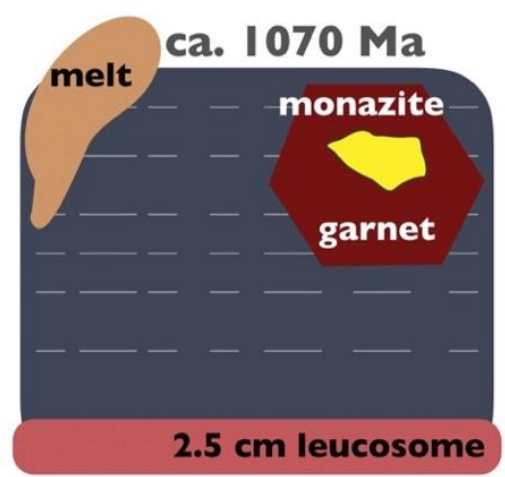

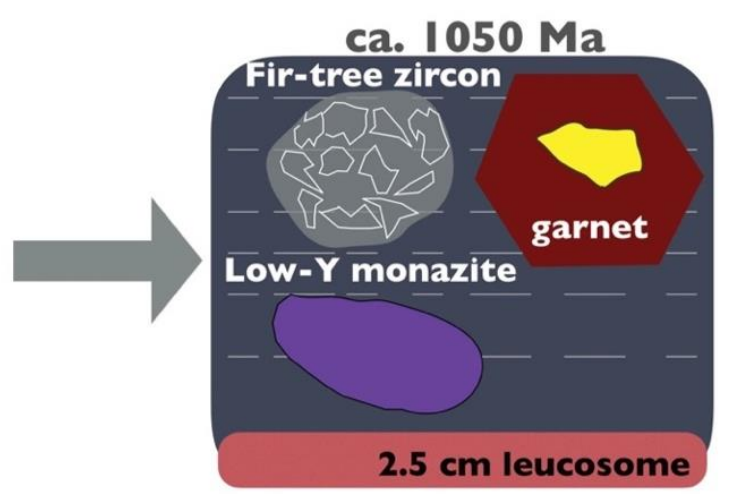

Figure 22: Schematic showing the interpreted timeline of melting, garnet growth, monazite growth, and zircon crystallization based on the data from the restite layers. High-Y monazite crystallized at ca. $1150 \mathrm{Ma}$. There may have been some melt due to muscovite dehydration-melting at ca. $1150 \mathrm{Ma}$. The $2.5 \mathrm{~cm}$ leucosome layer may have been produced at $1150 \mathrm{Ma}$. At ca. $1090 \mathrm{Ma}$, biotite dehydration-melting produces melt + garnet. The garnet grows around pre-existing high-Y monazite grains, and the melt dissolves the matrix monazite grains. Some melt is lost from the system by ca. $1070 \mathrm{Ma}$. Zircon fir-tree and low-Y monazite crystallization occurs from ca. 1070 to $1050 \mathrm{Ma}$. At $1030 \mathrm{Ma}$, rims on the monazite and zircon grains begin to crystallize due to decompression and fluid influx during post-orogenic collapse. 


\subsection{Evidence for Heterogeneous Melting}

Mineral assemblages from restite thin section 16TG-143-1 show differences along foliation-parallel layers. Some layers are predominately K-feldspar-rich while other layers are plagioclase-rich (Figure 18). There are several possible explanations for the differences. One possibility is that a layer that was initially biotite poor, and thus produced less melt and therefore less K-feldspar (Williams et al., in review). Another possibility is that reversal of Reaction-1 during melt crystallization may have produced the biotite in the plagioclase-rich layer. The presence of biotite around garnet and anhedral garnet is further evidence for reversal of Reaction-1, as garnet would be consumed in the reaction to produce biotite. If so, the evidence may suggest that layers record differences in retention of melt. A recent study suggests that the eastern Adirondack Mountains underwent heterogeneous partial melting (i.e., some layers crystallized melt while other layers lost melt) based on the rock mineral assemblages and monazite composition (Williams et al., in review). Differences in mineral assemblages in thin section 16-TG-143-1 may suggest that different amounts of melting or melt loss occurred within the rock.

In addition to differences in the major mineral phases, monazite trace elements in the two assemblages (plagioclase-rich and K-feldspar-rich) have distinctive compositions (Figure 17). Monazite in the K-feldspar-rich layer have enriched Y + HREE. Garnet is less abundant in this layer, thus there may have been more $\mathrm{Y}+\mathrm{HREE}$ available to monazite. LREE are depleted in monazite from the K-feldspar layer. During monazite dissolution, LREE are enriched in melt and thus if melt is lost, LREE are also removed reducing fertility for monazite crystallization (Kelsey et. al., 2008). The fewer monazite 
grains and lower abundance of LREE in the K-feldspar layer is consistent with melt loss, or alternatively, relatively less melting. We suggest that the plagioclase-rich layers likely retained melt, thus LREE, and were more fertile for monazite crystallization. The variable major phase and monazite composition in the layers may be evidence for heterogeneous melting or melt loss.

\subsection{Overview of the Metamorphic and Deformational History}

Recent workers have concluded that the Adirondack Mountains experienced at least two periods of melting, one at the ca. $1150 \mathrm{Ma}$ Shawinigan/AMCG event and another at the ca. 1050 Ma Ottawan event (Heumann et al., 2006; Bickford et al., 2008; McLelland et al., 2013; Williams et al., in review). The low Y + HREE monazite population and the fir-tree texture zircon population from the restite samples supports the argument for melting at ca. $1050 \mathrm{Ma}$, during the proposed timing of the Ottawan event (McLelland et al., 2013).

A recent study from a location west of Lake George shows that $\mathrm{Y}+\mathrm{HREE}$ in the 1150 Ma population significantly decreases (Y: 7500 to $2000 \mathrm{ppm}$ ) between 1170 to $1150 \mathrm{Ma}$ that is interpreted to be a result of garnet growth (Williams et al., in review). The Lake George samples are interpreted to have undergone biotite dehydration-melting during the Shawinigan/AMCG event with local melting during the Ottawan event. The Lake George and Rt. 22 data combined provides evidence for two melting events in the Adirondack Mountains. However, the two melt events are not equally preserved in the migmatite record. Bohlen et al., 1985 suggested that there is a 'bullseye' shape temperature gradient in the Adirondack Highlands with the highest temperatures near the AMCG intrusions. One explanation for the lack of significant Shawinigan melting at Rt. 
22 is that the rocks may have been located away from the high temperatures associated with the major AMCG intrusions. Still, the polymetamorphism in the region makes it difficult to discern if the 'bullseye' shape is accurate representation of the temperature gradient. Another hypothesis is that initial bulk composition played a role in determining the degree of melting in each event. At Lake George, biotite may have been consumed during a complete progression of Reaction-1 in the Shawinigan event, and therefore the rock was unfertile for further melting in the Ottawan event (Williams et al., in review). Further work is needed to understand the distribution and geometry of melting events throughout the entire Adirondack Mountains.

\subsection{Limitations of Zircon and Monazite Geochronology}

The petrochronological record from migmatites in the Adirondack Mountains provide meaningful insight into the tectonic history of the region, however there are limitations when interpreting tectonic histories - especially melt histories. One limitation is that monazite is soluble in melt, and thus periods of monazite growth may be erased or reset from the record (Kelsey et al., 2008), In our study, monazite was effectively preserved as inclusions in garnet, and therefore we do not believe that any populations were erased in the restite. However, it is likely that monazite was dissolved or reset, or both, in the leucosome layer based on the textures. Examining both the monazite date and associated trace element composition is essential to determine the timing of melting and garnet growth (Dumond et al., 2015; Williams et al., 2017; Williams et al., in review).

Zircon is more robust in melt (Kelsey et al., 2008), but zircon crystallization is more difficult to relate to melt reactions because trace element abundance is low and difficult to analyze via non-destructive techniques, such as electron microprobe analysis. 
Many zircon grains in this study are small $(20 \mu \mathrm{m})$, thus dating via LA-ICPMS destroys nearly the whole grain. Recent studies suggest that REE partitioning in zircon is an effective indicator of garnet growth in partially melted rocks (Taylor et al., 2015). Further exploratory work using the new Cameca SX-5 at the University of Massachusetts Amherst is underway to analyze trace elements in zircon. Further, Th/U ratios may not always be indicative of the source, suggesting that the ratio may not always accurately distinguish metamorphic from igneous zircon (Rubatto, 2017). More work using zircon as an indicator of melting is needed to complement the timing of melting from monazite.

A period of intense fluid alteration adds complexity when interpreting dates from monazite and zircon. Hydrothermal fluids have been known to be extremely destructive and may completely alter the U/Pb system in geochronometers (Pidgeon et al., 2000; Nasdala et. al., 2002; Williams et al., 2011). Some dates from zircon and monazite in the leucosome are suspected to reflect a period fluid alteration, evidenced by the alteration of monazite to apatite, uranothorite inclusions, and zircon rims depleted in U. Careful attention is needed with minerals suspected of hydrothermal fluid alteration as the dates may record a period of fluid alteration and not a period of crystallization. 


\section{CHAPTER 7}

\section{CONCLUSIONS}

A single roadcut near Whitehall, NY shows evidence for monazite and zircon growth at ca. 1150 and ca. $1050 \mathrm{Ma}$, however compositional and geochronological evidence strongly suggests that significant melting occurred at ca. 1050 Ma. Garnet growth and melt loss occurred prior to ca. $1065 \mathrm{Ma}$ as suggested by a decrease in $\mathrm{Y}+$ HREE $+\mathrm{U}$ in monazite and zircon grains. Zircon fir-tree sector zoning suggests melting beginning at ca. 1070. Rim domains enriched with $\mathrm{Y}+$ HREE and depleted in Th are indicative of retrograde metamorphism after ca. $1050 \mathrm{Ma}$ and likely signify decompression and post-orogenic collapse. The elongated shape of the restite monazite rim domains may indicate syndeformational monazite growth during shearing associated with the collapse phase.

An important conclusion from this study is that it is difficult to relate a leucosome layer to the host rock. The timing of leucosome production is difficult to interpret due to the contradictory date results from the ca. 1150 Ma zircon cores and ca. $1050 \mathrm{Ma}$ monazite grains. In addition, both monazite and zircon have evidence for fluid alteration around $1050 \mathrm{Ma}$. The leucosome may have been produced at ca. $1150 \mathrm{Ma}$, based on the dates and the magmatic $\mathrm{Th} / \mathrm{U}$ signature of the zircon cores. Alternatively, the leucosome may have been produced at ca. 1065 Ma melt based on the dates from monazite grains and zircon rims. It is also possible that the leucosome was injected from outside of the rock at either time. The study highlights the importance of separating layers in a migmatite in order to accurately determine the timing of melt and melt production.

Plagioclase-rich and K-feldspar-rich layers within the metapelitic gneisses have 
differences in major phases and monazite composition. Evidence from the K-feldsparrich layers suggest melt removal or less melting. Plagioclase-rich layers are interpreted to represent layers with melt retention and melt crystallization. Melt loss likely inhibits monazite crystallization as suggested by the low abundance of monazite in K-feldsparrich layers. A large-scale study comparing monazite grains within melt-rich and meltpoor layers is needed to better understand monazite crystallization during melting, melt loss and melt crystallization.

Timing of melting in polymetamorphic rocks is difficult to delineate based on geochronology alone. Migmatites in the eastern Adirondack Mountains have evidence for both ca. 1150 and ca. 1050 Ma melt events, however a careful examination of additional outcrops may provide further evidence for the full tectonic history in the region. Textural and geochemical data from monazite and zircon in combination with geochronology from all layers of a migmatite is essential for constraining the timing of metamorphism, deformation, and especially anatexis. 


\section{APPENDIX A}

\section{MONAZITE DATA}

Contact Kaitlyn Suarez at kaitlynsuarez93@gmail.com or Professor Michael Williams at mlw@ geo.umass.edu for excel spreadsheet files of monazite data.

Table 1: Restite Monazite Analyses

\begin{tabular}{|c|c|c|c|c|c|c|c|c|c|}
\hline Analysis & Date & unc & sigma & $\mathrm{Y}$ & $\mathrm{Th}$ & $\mathrm{U}$ & $\mathrm{Ca}$ & HREE & LREE \\
\hline & $(\mathrm{Ma})$ & & & (ppm) & $(\mathrm{ppm})$ & $(\mathrm{ppm})$ & $(\mathrm{ppm})$ & $(\mathrm{ppm})$ & $(\mathrm{ppm})$ \\
\hline 48 2018-9-28-16-TG-143-1-m03-purple-core & 1069 & 4.1 & 1 & 2158 & 31581 & 1413 & 13135 & 3306 & 544459 \\
\hline 49 2018-9-28-16-TG-143-1-m24-upper-left-orange & 1039 & 9.3 & 1 & 3455 & 32066 & 2614 & 7355 & 6254 & 548390 \\
\hline 50 2018-9-28-16-TG-143-1-m04-high-Y-core & 1148 & 7.4 & 1 & 17134 & 32540 & 782 & 6062 & 10320 & 524389 \\
\hline 51 2018-9-28-16-TG-143-1-m04-outer-core-purple & 1059 & 3.9 & 1 & 1224 & 31219 & 961 & 14054 & 2503 & 548149 \\
\hline 52 2018-9-28-16-TG-143-1-m04-outer-core-red-left & 1057 & 3.3 & 1 & 2264 & 35337 & 961 & 12612 & 3838 & 540178 \\
\hline 53 2018-9-28-16-TG-143-1-m04-rim & 1020 & 3 & 1 & 4056 & 26081 & 4065 & 7003 & 6150 & 544468 \\
\hline 54 2018-9-28-16-TG-143-1-m14-core-purple & 1031 & 6.4 & 1 & 1168 & 34432 & 957 & 14549 & 1477 & 543815 \\
\hline 55 2018-9-28-16-TG-143-1-m15-core-purple & 1059 & 6.2 & 1 & 1371 & 35294 & 1026 & 14458 & 2080 & 544742 \\
\hline 56 2018-9-28-16-TG-143-1-m26-high-Y & 1177 & 14.3 & 1 & 13334 & 19678 & 4074 & 4182 & 12229 & 539640 \\
\hline 59 2018-9-30-16-TG-143-1-m17-purple-center & 1065 & 23.9 & 1 & 2293 & 29993 & 1546 & 10604 & 4165 & 531920 \\
\hline 60 2018-9-30-16-TG-143-1-m13-purple-center & 1058 & 4.6 & 1 & 1218 & 32890 & 1031 & 13681 & 2461 & 547012 \\
\hline 61 2018-9-30-16-TG-143-1-m13-red-right & 1048 & 5.5 & 1 & 2189 & 30767 & 3021 & 6565 & 3202 & 553618 \\
\hline 62 2018-9-30-16-TG-143-1-m39-purple-center & 1038 & 12.8 & 1 & 1187 & 30143 & 1609 & 11910 & 1271 & 543736 \\
\hline 63 2018-9-30-16-TG-143-1-m25-high-Y-core & 1166 & 23 & 1 & 13410 & 21967 & 2941 & 4137 & 10339 & 532323 \\
\hline 64 2018-9-30-16-TG-143-1-m25-purple-upper & 1079 & 9.2 & 1 & 1497 & 25401 & 1051 & 9103 & 2525 & 556900 \\
\hline 13 ADK-16TG-143-1-m1-rightside-purple & 1062 & 5.6 & 1 & 1049 & 32886 & 980 & 14765 & 2023 & 538349 \\
\hline 14 ADK-16TG-143-1-m2-leftside-purple & 1057 & 5.6 & 1 & 1779 & 36377 & 1077 & 14141 & 2393 & 539352 \\
\hline 15 ADK-16TG-143-1-m5-bright-orange-right & 1056 & 9.1 & 1 & 7805 & 31545 & 2037 & 12735 & 6382 & 531157 \\
\hline
\end{tabular}


17 ADK-16TG-143-1-m40-purple-upper-left

18 ADK-16TG-143-1-m38-purple-lowCa-core

22 ADK-16TG-143-1-m40-rim

23 ADK-16TG-143-1-m32-bright-center-core

24 ADK-16TG-143-1-m38-red-highCa-upperleft

25 ADK-16TG-143-1-m15-rim-bottom

26 ADK-16TG-143-1-m35-purple-center

28 ADK-16TG-143-1-m28-bright-center-core

30 ADK-16TG-143-1-m20-bright-core-yellow

31 ADK-16TG-143-1-m20-midTh-rim

32 ADK-16TG-143-1-m20-dark-orangeTh-core

34 ADK-16TG-143-1-m43-core

35 ADK-16TG-143-1-m43-rim

36 ADK-16TG-143-1-m19-center-orange

74 2018-10-4-16-TG-143-1-m10-high-Y-center

75 2018-10-4-16-TG-143-1-m10-purple-center

76 2018-10-4-16-TG-143-1-m10-orange-rim

77 2018-10-4-16-TG-143-1-m06-purple-center

78 2018-10-4-16-TG-143-1-m36-purple-center

79 2018-10-4-16-TG-143-1-m37-purple-center

4 2017-05-27-16TG144-1-m2-core

5 2017-05-27-16TG144-1-m2-up-right-rim

6 2017-05-27-16TG144-1-m3-core

7 2017-05-27-16TG144-1-m3-up-rim

10 2017-05-27-16TG144-1-m9-left-in-rim

14 2017-05-27-16TG144-1-m13-low-right

15 2017-05-27-16TG144-1-m13-core-left

$\begin{array}{ccccccccc}1073 & 10.8 & 1 & 1204 & 31112 & 860 & 13718 & 1866 & 549320 \\ 1056 & 6.9 & 1 & 2004 & 26727 & 2603 & 6897 & 2776 & 557346 \\ 999 & 4 & 1 & 4672 & 24853 & 3519 & 6644 & 6865 & 533834 \\ 1165 & 15.5 & 1 & 15421 & 26196 & 3626 & 4479 & 11334 & 519413 \\ 1055 & 3.8 & 1 & 1230 & 30747 & 995 & 13124 & 1984 & 542722 \\ 1011 & 6.6 & 1 & 5619 & 20812 & 3893 & 6063 & 6359 & 541043 \\ 1042 & 4 & 1 & 1135 & 28952 & 936 & 13504 & 1292 & 539326 \\ 1155 & 13.6 & 1 & 15348 & 22167 & 3894 & 4696 & 10225 & 521137 \\ 1056 & 13.8 & 1 & 2094 & 25258 & 1136 & 7908 & 2018 & 548217 \\ 1008 & 4.1 & 1 & 4240 & 10704 & 4757 & 4610 & 6139 & 556170 \\ 1034 & 10.9 & 1 & 2721 & 13473 & 3623 & 4721 & 3855 & 562697 \\ 1050 & 6.1 & 1 & 3512 & 31154 & 1822 & 13172 & 5201 & 533261 \\ 978 & 11 & 1 & 3824 & 28330 & 2415 & 9093 & 5985 & 529325 \\ 1065 & 10 & 1 & 3305 & 30850 & 1360 & 12577 & 3941 & 531152 \\ 1145 & 15.3 & 1 & 15484 & 26334 & 3143 & 6394 & 12087 & 534589 \\ 1055 & 5 & 1 & 1282 & 29953 & 1240 & 9712 & 2086 & 556626 \\ 1040 & 6 & 1 & 3066 & 24399 & 4365 & 6403 & 5281 & 558268 \\ 1035 & 3.2 & 1 & 1288 & 29694 & 944 & 12225 & 1467 & 551417 \\ 1033 & 10.3 & 1 & 1093 & 30375 & 848 & 14110 & 1443 & 550215 \\ 1038 & 7.7 & 1 & 1047 & 31177 & 850 & 13840 & 1555 & 552974 \\ 1041 & 8.2 & 1 & 1449 & 37804 & 1046 & 15041 & 1560 & 525822 \\ 1012 & 5.4 & 1 & 8577 & 28090 & 10036 & 8941 & 9072 & 505029 \\ 1037 & 4.2 & 1 & 2440 & 33843 & 2523 & 12582 & 3876 & 530377 \\ 1028 & 3.3 & 1 & 6937 & 30967 & 10474 & 10055 & 7915 & 512146 \\ 1051 & 6 & 1 & 2610 & 34453 & 2939 & 13067 & 4373 & 529744 \\ 1062 & 9.5 & 1 & 19363 & 29839 & 4165 & 7829 & 13395 & 497464 \\ 1145 & 4.6 & 1 & 22494 & 29737 & 6387 & 5951 & 15479 & 500556\end{array}$


16 2017-05-27-16TG144-1-m6-core

17 2017-05-27-16TG144-1-m6-low-rim

90 2018-10-08-16Tg144-1-m17-core-right

91 2018-10-08-16Tg144-1-m17-center-left

92 2018-10-08-16Tg144-1-m8-core

93 2018-10-08-16Tg144-1-m4-core

94 2018-10-08-16Tg144-1-m4-upper-high-Y

95 2018-10-08-16Tg144-1-m1-core

96 2018-10-08-16Tg144-1-m1-up-right-rim

97 2018-10-08-16Tg144-1-m12-core

98 2018-10-08-16Tg144-1-m9-core-re

12 ADK-16TG-143-2-m5-purple-center

13 ADK-16TG-143-2-m6-orange-rim-Y

14 ADK-16TG-143-2-m17-bright-yellow-Y

15 ADK-16TG-143-2-m17-upper-left-orange-Y

16 ADK-16TG-143-2-m20-center-purple-Y

17 ADK-16TG-143-2-m22-center-purple-Y

18 ADK-16TG-143-2-m25-bot-right-Y

21 ADK-16TG-143-2_m20-rim-orange-Y

22 ADK-16TG-143-2_m24-center-bright-yellow-Y

23 ADK-16TG-143-2_m31-center-bright-yellow-Y

80 2018-10-4-16-TG-143-2-m26-right-red

81 2018-10-4-16-TG-143-2-m13-center-purple

82 2018-10-4-16-TG-143-2-m16-center-purple

83 2018-10-4-16-TG-143-2-m19-right-purple

84 2018-10-4-16-TG-143-2-m28-center-purple

85 2018-10-4-16-TG-143-2-m29-right-purple

$\begin{array}{lcccccccc}1043 & 4.7 & 1 & 1188 & 42757 & 1659 & 16171 & 2264 & 527986 \\ 1024 & 3.1 & 1 & 5121 & 34700 & 8081 & 10083 & 5607 & 521753 \\ 1167 & 7.4 & 1 & 17666 & 11147 & 9114 & 4323 & 15198 & 515383 \\ 1054 & 3.4 & 1 & 5230 & 28731 & 13384 & 11549 & 6969 & 509244 \\ 1170 & 5.8 & 1 & 14195 & 19635 & 5647 & 4099 & 13135 & 522157 \\ 1032 & 6 & 1 & 1417 & 34638 & 1123 & 15466 & 1355 & 534180 \\ 1054 & 2.5 & 1 & 6392 & 32151 & 8869 & 9773 & 7633 & 512303 \\ 1029 & 5.9 & 1 & 1410 & 35089 & 820 & 14989 & 1629 & 534641 \\ 1053 & 8.8 & 1 & 7422 & 29924 & 9392 & 10527 & 8049 & 513751 \\ 1065 & 4.8 & 1 & 2126 & 32924 & 1956 & 13018 & 6048 & 535296 \\ 1221 & 3.7 & 1 & 14703 & 32608 & 4437 & 6164 & 13934 & 515701 \\ 1080 & 4.7 & 1 & 1062 & 34080 & 1285 & 13267 & 1628 & 533421 \\ 1079 & 3.5 & 1 & 2455 & 20551 & 5393 & 5674 & 4181 & 543987 \\ 1180 & 7.5 & 1 & 14501 & 24196 & 4920 & 4398 & 13364 & 515558 \\ 1040 & 3.6 & 1 & 2962 & 27376 & 2135 & 10245 & 4566 & 539778 \\ 1044 & 6.4 & 1 & 1133 & 41356 & 1522 & 14815 & 2052 & 530212 \\ 1047 & 3.1 & 1 & 1045 & 43791 & 1388 & 15987 & 2490 & 523324 \\ 1063 & 4.6 & 1 & 2057 & 26980 & 3779 & 7096 & 2310 & 543441 \\ 1047 & 5.5 & 1 & 3022 & 28165 & 4874 & 6873 & 3495 & 534837 \\ 1147 & 10.5 & 1 & 20033 & 34805 & 2114 & 6859 & 11451 & 503123 \\ 1169 & 6.6 & 1 & 22993 & 33849 & 1129 & 6593 & 11933 & 498837 \\ 1083 & 8.4 & 1 & 2285 & 30809 & 1159 & 11226 & 2032 & 549410 \\ 1046 & 8.4 & 1 & 1045 & 39071 & 1039 & 14785 & 1571 & 543071 \\ 1012 & 2.7 & 1 & 1263 & 38221 & 1499 & 14432 & 712 & 531942 \\ 1051 & 5.5 & 1 & 1817 & 31700 & 3317 & 7415 & 2576 & 558427 \\ 1042 & 8 & 1 & 935 & 34942 & 965 & 14765 & 646 & 541960 \\ 1035 & 5.8 & 1 & 896 & 33790 & 794 & 14311 & 827 & 540943\end{array}$


Table 2: Leucosome Monazite Analyses

\begin{tabular}{llccccccccc}
\hline \multicolumn{1}{c}{ Analysis } & Date & unc & sigma & Y & Th & U & Ca & HREE & LREE \\
\hline & $(\mathrm{Ma})$ & & & $(\mathrm{ppm})$ & $(\mathrm{ppm})$ & $(\mathrm{ppm})$ & $(\mathrm{ppm})$ & $(\mathrm{ppm})$ & $(\mathrm{ppm})$ \\
\hline 3 ADK-16TG-143-5-m7-upper-core & 1057 & 3.6 & 1 & 4163 & 51126 & 3116 & 16623 & 3830 & 508184 \\
4 ADK-16TG-143-5-m7-lower-core & 1057 & 8.1 & 1 & 2385 & 79678 & 2078 & 20204 & 3347 & 483593 \\
5 ADK-16TG-143-5-m6-upper & 1061 & 2.1 & 1 & 4996 & 97023 & 1169 & 20434 & 2160 & 455478 \\
6 ADK-16TG-143-5-m2-upper & 1067 & 3.5 & 1 & 4365 & 84378 & 2141 & 20141 & 3333 & 470414 \\
7 ADK-16TG-143-5-m2-bottom & 1066 & 2.2 & 1 & 7381 & 80895 & 3571 & 19535 & 5649 & 467912 \\
8 ADK-16TG-143-5-m12-core-bottom & 1067 & 11.8 & 1 & 3090 & 87008 & 2347 & 20506 & 1146 & 467549 \\
10 adk-16tg-143-5-M6-high-Y-core & 1048 & 8.9 & 1 & 15526 & 85386 & 2046 & 21232 & 7643 & 449139 \\
11 adk-16tg-143-5-M12-high-Y-core & 1062 & 8.5 & 1 & 15585 & 77699 & 4774 & 17033 & 8671 & 465295 \\
12 adk-16tg-143-5-M07-right-edge & 1030 & 16.3 & 1 & 6006 & 63094 & 2972 & 11809 & 4737 & 501624 \\
37 ADK-16TG-143-5-m13-highU-right & 1049 & 3.5 & 1 & 5342 & 69368 & 6013 & 13680 & 4279 & 485442
\end{tabular}




\section{APPENDIX B}

\section{ZIRCON DATA}

Table 3: Restite Zircon U/Pb Analyses

\begin{tabular}{|c|c|c|c|c|c|c|c|c|}
\hline Analysis & $\mathrm{U}$ & $\mathrm{Th}$ & $206 \mathrm{~Pb}$ & $\mathrm{Th} / \mathrm{U}$ & $206 \mathrm{~Pb}$ & \pm & Conc & Texture \\
\hline & $(\mathrm{ppm})$ & $(\mathrm{ppm})$ & $204 \mathrm{~Pb}$ & & $207 \mathrm{~Pb}$ & $(\mathrm{Ma})$ & $(\%)$ & \\
\hline \multicolumn{9}{|l|}{ In-situ Analysis } \\
\hline 16TG143-2_thin_section-SAMPLE 1 Spot 1 & 190 & 163 & 12941 & 0.856 & 1011.0 & 26.3 & 100.3 & Bright CL rim \\
\hline 16TG143-2_thin_section-SAMPLE 1 Spot 25 & 181 & 18 & 70792 & 0.099 & 1019.9 & 22.4 & 100.5 & Fir-tree rim \\
\hline Williams 16TG-143-1-TS june 9 2017-SAMPLE 1 Spot 16 & 143 & 15 & 129308 & 0.105 & 1027.5 & 21.6 & 99.8 & Bright CL rim \\
\hline 16TG143-2_thin_section-SAMPLE 1 Spot 13 & 468 & 2 & 19625 & 0.004 & 1027.9 & 19.1 & 98.4 & Bright CL rim \\
\hline 16TG143-2_thin_section-SAMPLE 1 Spot 27 & 224 & 12 & 70645 & 0.054 & 1032.2 & 23.0 & 99.4 & Fir-tree \\
\hline Williams 16TG-143-1-TS june 9 2017-SAMPLE 1 Spot 31 & 146 & 9 & 108319 & 0.062 & 1032.2 & 20.1 & 100.2 & Bright CL rim \\
\hline 16TG143-2_thin_section-SAMPLE 1 Spot 34 & 384 & 2 & 22854 & 0.005 & 1039.8 & 21.6 & 98.4 & $\operatorname{Rim}$ \\
\hline 16TG143-2_thin_section-SAMPLE 1 Spot 26 & 311 & 32 & 32820 & 0.103 & 1040.4 & 22.2 & 100.9 & Bright CL core \\
\hline Williams 16TG-143-1-TS june 9 2017-SAMPLE 1 Spot 34 & 122 & 11 & 13046 & 0.090 & 1048.7 & 20.7 & 98.4 & Bright CL rim \\
\hline 16TG143-2_thin_section-SAMPLE 1 Spot 32 & 140 & 8 & 13094 & 0.057 & 1049.2 & 20.8 & 98.8 & Fir-tree rim \\
\hline Williams 16TG-143-1-TS june 9 2017-SAMPLE 1 Spot 4 & 151 & 7 & 15772 & 0.046 & 1050.0 & 27.5 & 98.0 & Bright CL \\
\hline 16TG143-2_thin_section-SAMPLE 1 Spot 14 & 141 & 16 & 37249 & 0.113 & 1050.6 & 26.3 & 98.9 & Bright CL Core \\
\hline Williams 16TG-143-1-TS june 9 2017-SAMPLE 1 Spot 32 & 292 & 24 & 179460 & 0.082 & 1050.8 & 17.1 & 98.8 & Fir-tree \\
\hline 16TG143-2_thin_section-SAMPLE 1 Spot 3 & 166 & 13 & 81581 & 0.078 & 1053.8 & 21.4 & 99.6 & Bright CL Core \\
\hline Williams 16TG-143-1-TS june 9 2017-SAMPLE 1 Spot 35 & 185 & 10 & 54470 & 0.054 & 1054.0 & 17.4 & 98.9 & Fir-tree \\
\hline 16TG143-2_thin_section-SAMPLE 1 Spot 24 & 259 & 17 & 121460 & 0.066 & 1062.5 & 19.8 & 99.1 & Bright CL Rim \\
\hline Williams 16TG-143-1-TS june 9 2017-SAMPLE 1 Spot 25 & 141 & 12 & 77638 & 0.085 & 1064.3 & 21.5 & 95.1 & Bright CL Core \\
\hline Williams 16TG-143-1-TS june 9 2017-SAMPLE 1 Spot 15 & 191 & 10 & 38498 & 0.052 & 1065.8 & 23.4 & 98.5 & Bright CL Core \\
\hline Williams 16TG-143-1-TS june 9 2017-SAMPLE 1 Spot 19 & 377 & 15 & 31182 & 0.040 & 1096.1 & 30.0 & 95.1 & Core \\
\hline
\end{tabular}


Williams 16TG-143-1-TS june 9 2017-SAMPLE 1 Spot 11 Williams 16TG-143-1-TS june 9 2017-SAMPLE 1 Spot 29 Williams 16TG-143-1-TS june 9 2017-SAMPLE 1 Spot 18 Williams 16TG-143-1-TS june 9 2017-SAMPLE 1 Spot 7 Williams 16TG-143-1-TS june 9 2017-SAMPLE 1 Spot 13 Williams 16TG-143-1-TS june 9 2017-SAMPLE 1 Spot 27 16TG143-2_thin_section-SAMPLE 1 Spot 16

\section{Separate Analysis}

16TG-143-1-Spot 018 16TG-143-1-Spot 232 16TG-143-1-Spot 026 16TG-143-1-Spot 043 16TG-143-1-Spot 175 16TG-143-1-Spot 188 16TG-143-1-Spot 121 16TG-143-1-Spot 025 16TG-143-1-Spot 044 16TG-143-1-Spot 165 16TG-143-1-Spot 031 16TG-143-1-Spot 227 16TG-143-1-Spot 100 16TG-143-1-Spot 186 16TG-143-1-Spot 259 16TG-143-1-Spot 046 16TG-143-1-Spot 178 16TG-143-1-Spot 124 16TG-143-1-Spot 302

$\begin{array}{cccccccc}473 & 8 & 97238 & 0.017 & 1135.6 & 23.5 & 95.8 & \text { Core } \\ 768 & 42 & 1364473 & 0.055 & 1140.4 & 14.0 & 96.5 & \text { Core } \\ 407 & 48 & 67931 & 0.118 & 1149.1 & 21.8 & 97.1 & \text { Core } \\ 516 & 125 & 1687613 & 0.242 & 1173.3 & 19.3 & 97.5 & \text { Core } \\ 657 & 168 & 138077 & 0.256 & 1183.4 & 21.7 & 95.2 & \text { Core } \\ 627 & 87 & 178615 & 0.139 & 1188.4 & 15.2 & 95.2 & \text { Core } \\ 493 & 227 & 41932 & 0.460 & 1292.0 & 19.5 & 98.7 & \text { Core } \\ & & & & & & & \\ 120 & 5 & 91677 & 0.042 & 1018.0 & 20.8 & 100.5 & \text { Fir-tree } \\ 162 & 9 & 13413 & 0.055 & 1019.3 & 22.7 & 99.6 & \text { Fir-tree } \\ 133 & 7 & 12819 & 0.053 & 1021.2 & 19.7 & 99.4 & \text { Fir-tree } \\ 157 & 8 & 45933 & 0.051 & 1021.6 & 21.3 & 100.5 & \text { Fir-tree } \\ 212 & 5 & 66085 & 0.024 & 1023.7 & 17.6 & 100.3 & \text { Fir-tree } \\ 118 & 6 & 32156 & 0.051 & 1024.6 & 26.0 & 100.1 & \text { Fir-tree } \\ 125 & 8 & 24603 & 0.064 & 1025.3 & 26.1 & 100.7 & \text { Fir-tree } \\ 139 & 9 & 26522 & 0.065 & 1025.7 & 20.8 & 99.4 & \text { Fir-tree } \\ 166 & 9 & 23281 & 0.054 & 1025.9 & 19.5 & 99.5 & \text { Fir-tree } \\ 120 & 5 & 25045 & 0.042 & 1026.2 & 25.4 & 100.8 & \text { Fir-tree } \\ 142 & 7 & 42568 & 0.049 & 1026.5 & 19.4 & 100.9 & \text { Fir-tree } \\ 151 & 10 & 10507 & 0.066 & 1026.7 & 27.2 & 99.8 & \text { Fir-tree } \\ 232 & 1 & 30348 & 0.004 & 1027.9 & 20.8 & 100.0 & \text { Fir-tree } \\ 106 & 7 & 20079 & 0.066 & 1028.4 & 26.7 & 100.9 & \text { Fir-tree } \\ 133 & 9 & 66118 & 0.068 & 1028.7 & 25.2 & 100.5 & \text { Fir-tree } \\ 276 & 4 & 65179 & 0.014 & 1029.8 & 15.3 & 100.4 & \text { Fir-tree } \\ 134 & 6 & 118985 & 0.045 & 1030.5 & 19.3 & 100.2 & \text { Fir-tree } \\ 147 & 7 & 48952 & 0.048 & 1030.6 & 21.9 & 99.8 & \text { Fir-tree } \\ 134 & 8 & 60270 & 0.060 & 1030.6 & 19.6 & 100.7 & \text { Fir-tree }\end{array}$




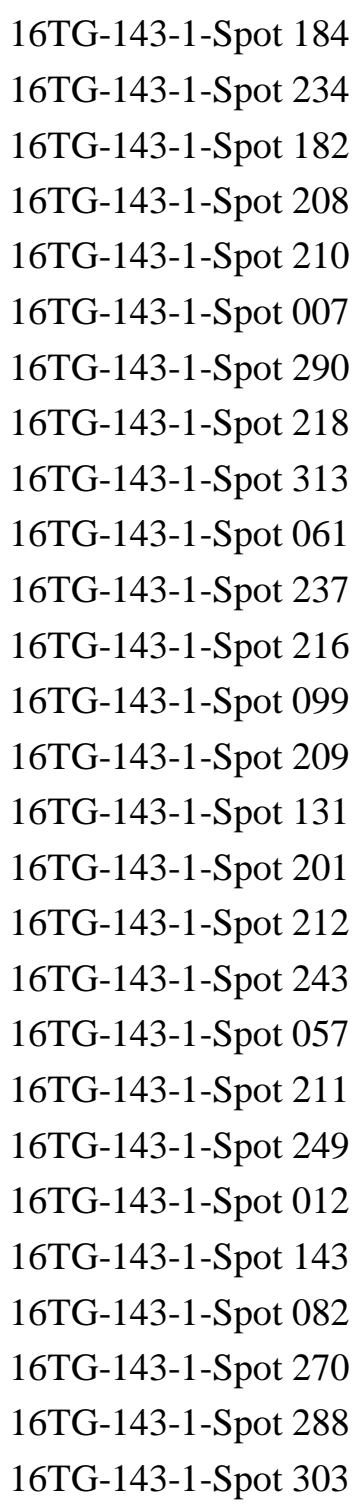

$\begin{array}{cccccccl}357 & 4 & 64691 & 0.011 & 1030.9 & 17.4 & 100.1 & \text { Fir-tree } \\ 161 & 7 & 90533 & 0.043 & 1031.7 & 21.9 & 100.2 & \text { Fir-tree } \\ 126 & 7 & 30564 & 0.056 & 1032.2 & 20.9 & 100.6 & \text { Fir-tree } \\ 175 & 10 & 96941 & 0.057 & 1034.0 & 20.4 & 98.9 & \text { Fir-tree } \\ 122 & 6 & 36564 & 0.049 & 1034.9 & 21.7 & 99.6 & \text { Fir-tree } \\ 135 & 9 & 42180 & 0.067 & 1035.6 & 20.0 & 99.8 & \text { Fir-tree } \\ 217 & 6 & 36500 & 0.028 & 1036.3 & 17.6 & 100.2 & \text { Fir-tree } \\ 113 & 6 & 30569 & 0.053 & 1036.5 & 23.2 & 100.6 & \text { Fir-tree } \\ 138 & 5 & 116426 & 0.036 & 1036.7 & 19.4 & 100.1 & \text { Fir-tree } \\ 125 & 8 & 58431 & 0.064 & 1037.0 & 23.0 & 100.8 & \text { Fir-tree } \\ 122 & 6 & 74230 & 0.049 & 1037.2 & 23.6 & 100.1 & \text { Fir-tree } \\ 123 & 8 & 36110 & 0.065 & 1037.3 & 20.5 & 98.8 & \text { Fir-tree } \\ 110 & 6 & 17761 & 0.054 & 1037.4 & 24.8 & 100.2 & \text { Fir-tree } \\ 125 & 5 & 79415 & 0.040 & 1037.8 & 18.5 & 100.1 & \text { Fir-tree } \\ 135 & 6 & 70007 & 0.044 & 1037.8 & 23.4 & 98.9 & \text { Fir-tree } \\ 131 & 6 & 860900 & 0.046 & 1038.0 & 23.4 & 99.8 & \text { Fir-tree } \\ 131 & 9 & 146496 & 0.069 & 1038.3 & 16.7 & 99.4 & \text { Fir-tree } \\ 143 & 5 & 24842 & 0.035 & 1038.4 & 23.0 & 98.4 & \text { Fir-tree } \\ 143 & 10 & 78182 & 0.070 & 1038.7 & 22.5 & 98.9 & \text { Fir-tree } \\ 133 & 6 & 36041 & 0.045 & 1039.4 & 21.5 & 99.4 & \text { Fir-tree } \\ 127 & 6 & 20096 & 0.047 & 1039.7 & 23.0 & 100.1 & \text { Fir-tree } \\ 111 & 8 & 114130 & 0.072 & 1039.8 & 16.5 & 100.2 & \text { Fir-tree } \\ 165 & 9 & 310640 & 0.054 & 1040.3 & 18.7 & 98.5 & \text { Fir-tree } \\ 130 & 7 & 17730 & 0.054 & 1040.5 & 19.7 & 100.0 & \text { Fir-tree } \\ 111 & 7 & 38120 & 0.063 & 1041.2 & 21.1 & 100.9 & \text { Fir-tree } \\ 146 & 6 & 26869 & 0.041 & 1041.9 & 15.3 & 99.0 & \text { Fir-tree } \\ 145 & 7 & 102784 & 0.048 & 1042.0 & 20.1 & 100.6 & \text { Fir-tree }\end{array}$




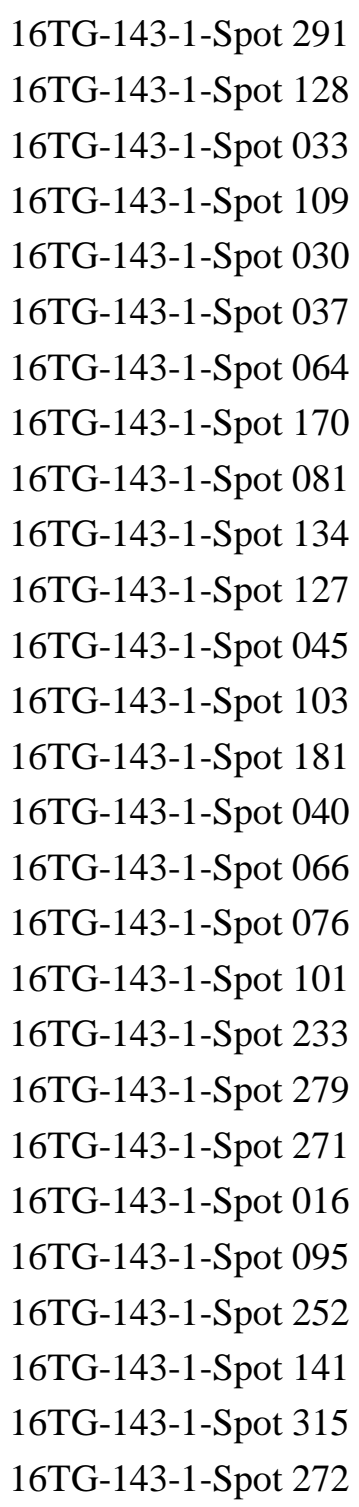

$\begin{array}{cccccccl}379 & 1 & 130762 & 0.003 & 1042.2 & 19.3 & 98.2 & \text { Fir-tree } \\ 126 & 8 & 51122 & 0.063 & 1042.9 & 20.2 & 99.8 & \text { Fir-tree } \\ 117 & 8 & 34666 & 0.068 & 1043.0 & 22.3 & 98.5 & \text { Fir-tree } \\ 130 & 7 & 998143 & 0.054 & 1043.6 & 20.2 & 98.5 & \text { Fir-tree } \\ 114 & 7 & 330437 & 0.061 & 1043.7 & 19.0 & 98.5 & \text { Fir-tree } \\ 136 & 5 & 36787 & 0.037 & 1043.8 & 21.7 & 98.0 & \text { Fir-tree } \\ 135 & 6 & 45473 & 0.044 & 1044.4 & 31.5 & 99.4 & \text { Fir-tree } \\ 106 & 9 & 29780 & 0.085 & 1044.5 & 19.6 & 98.5 & \text { Fir-tree } \\ 133 & 6 & 19267 & 0.045 & 1044.8 & 20.2 & 100.4 & \text { Fir-tree } \\ 133 & 8 & 228304 & 0.060 & 1045.4 & 21.7 & 99.8 & \text { Fir-tree } \\ 228 & 10 & 20629 & 0.044 & 1045.9 & 22.6 & 100.5 & \text { Fir-tree } \\ 127 & 5 & 30455 & 0.039 & 1046.1 & 19.2 & 99.4 & \text { Fir-tree } \\ 213 & 5 & 30325 & 0.023 & 1046.1 & 20.1 & 100.3 & \text { Fir-tree } \\ 117 & 8 & 141724 & 0.068 & 1046.2 & 25.8 & 98.6 & \text { Fir-tree } \\ 129 & 13 & 281501 & 0.101 & 1046.3 & 20.0 & 98.9 & \text { Fir-tree } \\ 150 & 6 & 57619 & 0.040 & 1046.9 & 20.9 & 98.0 & \text { Fir-tree } \\ 139 & 6 & 41645 & 0.043 & 1047.0 & 20.2 & 98.9 & \text { Fir-tree } \\ 108 & 7 & 15000 & 0.065 & 1047.7 & 19.6 & 98.8 & \text { Fir-tree } \\ 129 & 8 & 67038 & 0.062 & 1047.7 & 17.3 & 98.7 & \text { Fir-tree } \\ 118 & 10 & 14843 & 0.085 & 1047.7 & 24.3 & 100.6 & \text { Fir-tree } \\ 130 & 5 & 149372 & 0.038 & 1048.6 & 23.5 & 99.9 & \text { Fir-tree } \\ 106 & 7 & 23314 & 0.066 & 1048.8 & 20.1 & 99.2 & \text { Fir-tree } \\ 149 & 8 & 57667 & 0.054 & 1049.1 & 23.0 & 99.5 & \text { Fir-tree } \\ 135 & 7 & 559043 & 0.052 & 1049.3 & 19.5 & 99.6 & \text { Fir-tree } \\ 128 & 7 & 57055 & 0.055 & 1049.3 & 20.4 & 99.4 & \text { Fir-tree } \\ 132 & 6 & 231594 & 0.046 & 1049.9 & 20.5 & 99.8 & \text { Fir-tree } \\ 115 & 8 & 41965 & 0.070 & 1050.9 & 20.1 & 99.4 & \text { Fir-tree }\end{array}$




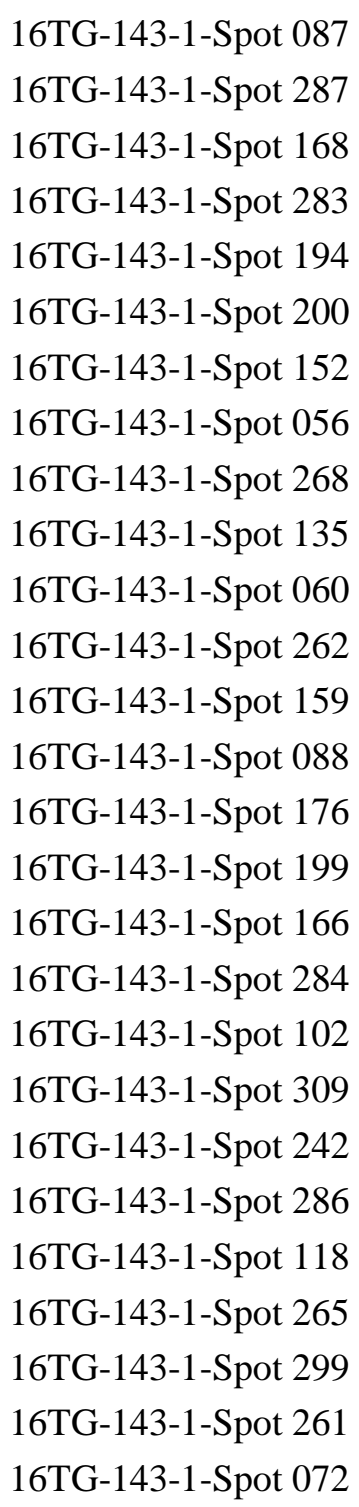

$\begin{array}{cccccccl}138 & 7 & 13613 & 0.051 & 1051.0 & 19.1 & 98.2 & \text { Fir-tree } \\ 144 & 10 & 67093 & 0.070 & 1051.3 & 21.5 & 98.6 & \text { Fir-tree } \\ 116 & 8 & 53133 & 0.069 & 1051.4 & 23.2 & 98.1 & \text { Fir-tree } \\ 122 & 8 & 15521 & 0.065 & 1051.5 & 20.6 & 98.4 & \text { Fir-tree } \\ 116 & 4 & 19556 & 0.035 & 1051.5 & 21.3 & 98.5 & \text { Fir-tree } \\ 141 & 8 & 146013 & 0.057 & 1052.1 & 23.4 & 98.6 & \text { Fir-tree } \\ 441 & 3 & 95572 & 0.007 & 1052.1 & 19.7 & 100.4 & \text { Fir-tree } \\ 142 & 6 & 36918 & 0.042 & 1052.2 & 22.2 & 99.9 & \text { Fir-tree } \\ 118 & 7 & 31292 & 0.059 & 1052.6 & 18.6 & 99.3 & \text { Fir-tree } \\ 128 & 6 & 34906 & 0.047 & 1053.1 & 21.4 & 99.6 & \text { Fir-tree } \\ 147 & 8 & 27123 & 0.054 & 1053.7 & 20.8 & 98.7 & \text { Fir-tree } \\ 115 & 6 & 22346 & 0.052 & 1053.8 & 20.4 & 99.7 & \text { Fir-tree } \\ 124 & 7 & 21958 & 0.057 & 1054.0 & 28.4 & 98.0 & \text { Fir-tree } \\ 129 & 9 & 65313 & 0.070 & 1054.7 & 16.8 & 98.1 & \text { Fir-tree } \\ 141 & 7 & 46860 & 0.050 & 1054.8 & 22.5 & 98.0 & \text { Fir-tree } \\ 130 & 8 & 57388 & 0.062 & 1055.0 & 19.2 & 100.5 & \text { Fir-tree } \\ 129 & 6 & 192493 & 0.046 & 1055.3 & 20.8 & 99.1 & \text { Fir-tree } \\ 113 & 7 & 129981 & 0.062 & 1055.7 & 19.9 & 99.5 & \text { Fir-tree } \\ 138 & 8 & 24098 & 0.058 & 1056.1 & 20.2 & 98.5 & \text { Fir-tree } \\ 145 & 6 & 71859 & 0.041 & 1056.8 & 16.1 & 99.7 & \text { Fir-tree } \\ 134 & 4 & 56201 & 0.030 & 1057.6 & 21.8 & 99.0 & \text { Fir-tree } \\ 141 & 6 & 22397 & 0.043 & 1058.5 & 20.6 & 98.1 & \text { Fir-tree } \\ 119 & 8 & 128161 & 0.067 & 1058.5 & 21.7 & 98.4 & \text { Fir-tree } \\ 120 & 6 & 58937 & 0.050 & 1061.1 & 26.7 & 99.0 & \text { Fir-tree } \\ 129 & 6 & 25272 & 0.046 & 1061.3 & 17.1 & 99.6 & \text { Fir-tree } \\ 101 & 7 & 35024 & 0.069 & 1061.9 & 17.8 & 98.3 & \text { Fir-tree } \\ 107 & 8 & 20836 & 0.074 & 1062.4 & 20.9 & 98.5 & \text { Fir-tree }\end{array}$


16TG-143-1-Spot 230 16TG-143-1-Spot 306 16TG-143-1-Spot 120 16TG-143-1-Spot 217 16TG-143-1-Spot 162 16TG-143-1-Spot 119 16TG-143-1-Spot 278 16TG-143-1-Spot 115 16TG-143-1-Spot 002 16TG-143-1-Spot 003

16TG-143-1-Spot 059

16TG-143-1-Spot 001 16TG-143-1-Spot 086 16TG-143-1-Spot 256 16TG-143-1-Spot 213 16TG-143-1-Spot 133 16TG-143-1-Spot 050 16TG-143-1-Spot 312 16TG-143-1-Spot 083

$\begin{array}{cccccccc}137 & 5 & 1510624 & 0.037 & 1062.7 & 18.9 & 98.4 & \text { Fir-tree } \\ 143 & 5 & 136094 & 0.035 & 1063.7 & 24.7 & 98.1 & \text { Fir-tree } \\ 372 & 2 & 53730 & 0.005 & 1063.7 & 23.2 & 98.0 & \text { Fir-tree } \\ 123 & 6 & 26320 & 0.049 & 1063.9 & 26.3 & 98.0 & \text { Fir-tree } \\ 147 & 5 & 70987 & 0.034 & 1064.2 & 24.2 & 99.2 & \text { Fir-tree } \\ 121 & 6 & 78637 & 0.050 & 1064.4 & 16.3 & 98.9 & \text { Fir-tree } \\ 122 & 4 & 35100 & 0.033 & 1066.9 & 25.2 & 99.4 & \text { Fir-tree } \\ 215 & 5 & 14313 & 0.023 & 1068.4 & 22.6 & 98.2 & \text { Fir-tree } \\ 84 & 6 & 53388 & 0.072 & 1068.4 & 20.2 & 98.5 & \text { Fir-tree } \\ 116 & 6 & 202138 & 0.052 & 1068.8 & 17.7 & 99.5 & \text { Fir-tree } \\ 350 & 6 & 78303 & 0.017 & 1070.0 & 19.8 & 99.1 & \text { Bright CL/Fir- } \\ & & & & & & & \text { tree } \\ 87 & 6 & 69416 & 0.069 & 1075.8 & 18.2 & 98.5 & \text { Bright CL/Fir- } \\ 180 & 4 & 176561 & 0.022 & 1088.7 & 26.7 & 99.8 & \text { Bright CL } \\ 288 & 12 & 44851 & 0.042 & 1116.1 & 20.2 & 100.4 & \text { Core } \\ 239 & 21 & 77119 & 0.088 & 1137.3 & 17.9 & 98.0 & \text { Core } \\ 253 & 11 & 57038 & 0.043 & 1148.3 & 23.4 & 98.3 & \text { Core } \\ 251 & 27 & 22789 & 0.108 & 1175.8 & 18.6 & 100.8 & \text { Core } \\ 271 & 81 & 146681 & 0.299 & 1240.2 & 15.8 & 100.4 & \text { Core } \\ 345 & 96 & 193027 & 0.278 & 1286.4 & 16.9 & 100.0 & \text { Core }\end{array}$


Table 4: Leucosome Zircon U/Pb Analyses

\begin{tabular}{|c|c|c|c|c|c|c|c|c|}
\hline Analysis & $\mathrm{U}$ & $\mathrm{Th}$ & $206 \mathrm{~Pb}$ & $\mathrm{Th} / \mathrm{U}$ & $206 \mathrm{~Pb}$ & \pm & Conc & Texture \\
\hline & (ppm & (ppm) & $204 \mathrm{~Pb}$ & & $207 \mathrm{~Pb}$ & $\begin{array}{c}\text { (Ma } \\
\text { ) }\end{array}$ & $(\%)$ & \\
\hline \multicolumn{9}{|l|}{ In-situ } \\
\hline 16TG-143-5 Spot 7 & 330 & 7 & 107373 & 0.021 & 1030.8 & 22.0 & 99.4 & Dark CL Rim \\
\hline 16TG-143-5 Spot 19 & 217 & 27 & 21926 & 0.125 & 1031.2 & 18.3 & 99.7 & Fir-Tree \\
\hline 16TG-143-5 Spot 20 & 593 & 249 & 97454 & 0.420 & 1110.6 & 21.0 & 99.4 & Core \\
\hline 16TG-143-5 Spot 13 & 496 & 185 & 43927 & 0.373 & 1150.7 & 22.9 & 98.8 & Core \\
\hline 16TG-143-5 Spot 28 & 623 & 408 & 75892 & 0.655 & 1157.1 & 26.4 & 99.7 & Core \\
\hline 16TG-143-5 Spot 22 & 339 & 58 & 33234 & 0.171 & 1158.7 & 16.4 & 99.3 & Core \\
\hline 16TG-143-5 Spot 2 & 1009 & 617 & 171323 & 0.612 & 1167.8 & 17.2 & 98.4 & Core \\
\hline \multicolumn{9}{|l|}{ Separate } \\
\hline 16TG-143-2 Spot 20 & 452 & 56 & 31584 & 0.124 & 1050.0 & 20.3 & 97.5 & Rim \\
\hline 16TG-143-2 Spot 24 & 452 & 59 & 68759 & 0.130 & 1050.5 & 18.1 & 99.1 & $\operatorname{Rim}$ \\
\hline 16TG-143-2 Spot 22 & 892 & 290 & 219252 & 0.325 & 1117.7 & 21.0 & 100.6 & Core \\
\hline 16TG-143-2 Spot 16 & 776 & 115 & 127444 & 0.148 & 1131.1 & 20.0 & 97.1 & Core \\
\hline 16TG-143-2 Spot 19 & 1158 & 570 & 334403 & 0.492 & 1150.1 & 18.0 & 99.2 & Core \\
\hline 16TG-143-2 Spot 30 & 678 & 272 & 183553 & 0.401 & 1161.2 & 22.9 & 99.2 & Core \\
\hline 16TG-143-2 Spot 18 & 597 & 281 & 126981 & 0.471 & 1163.5 & 21.3 & 99.3 & Core \\
\hline 16TG-143-2 Spot 10 & 471 & 191 & 85151 & 0.405 & 1164.5 & 19.9 & 99.0 & Core \\
\hline 16TG-143-2 Spot 4 & 882 & 277 & 295575 & 0.314 & 1165.3 & 19.6 & 98.9 & Core \\
\hline 16TG-143-2 Spot 7 & 1344 & 602 & 335639 & 0.448 & 1172.0 & 21.2 & 99.6 & Core \\
\hline 16TG-143-2 Spot 12 & 784 & 266 & 211999 & 0.339 & 1173.5 & 19.5 & 98.0 & Core \\
\hline 16TG-143-2 Spot 28 & 1674 & 808 & 186659 & 0.483 & 1176.1 & 22.2 & 98.3 & Core \\
\hline 16TG-143-2 Spot 27 & 806 & 398 & 78644 & 0.494 & 1180.8 & 17.8 & 98.3 & Core \\
\hline 16TG-143-2 Spot 14 & 1154 & 518 & 214894 & 0.449 & 1202.2 & 22.4 & 98.0 & Core \\
\hline
\end{tabular}




\section{APPENDIX C}

\section{MAJOR MINERAL COMPOSITIONS}

The mineral composition for garnet, feldspar, plagioclase and biotite were identified using electron microprobe quantitative analysis (EMPA). Garnet, biotite, feldspar, and plagioclase were first mapped on the SX50 to observe any compositional differences prior to quantitative analysis. The thin-section 16TG-143-1 is the restite and thin-section 16TG-143-5 is the leucosome. The results for the mineral compositions are presented in the figures below.

\section{GARNET}

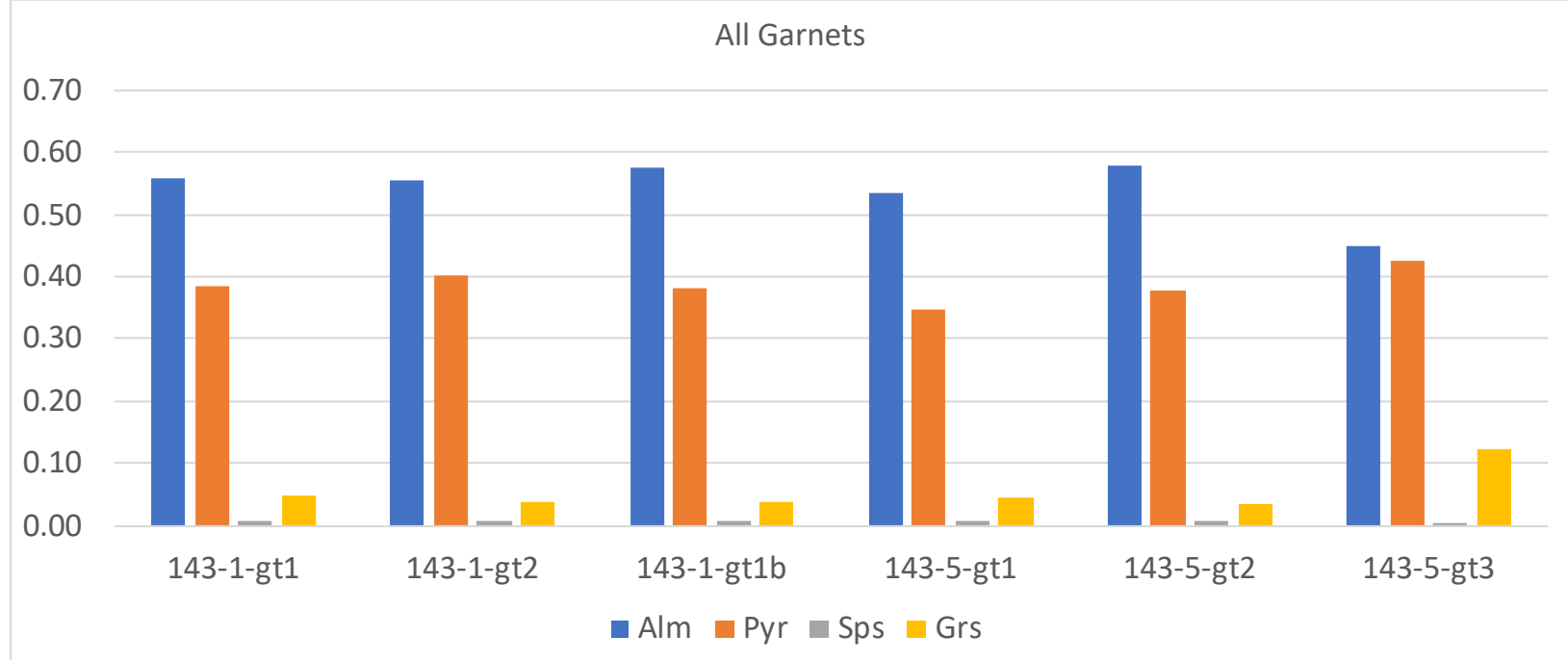

Figure 23: Comparison of the composition of garnet in all samples (restite and leucosome). 
16TG-143-1-Garnet1

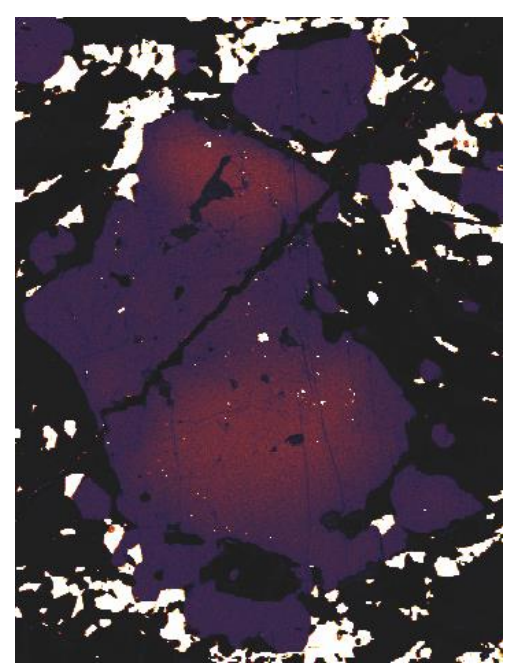

16TG-143-1-Garnet2

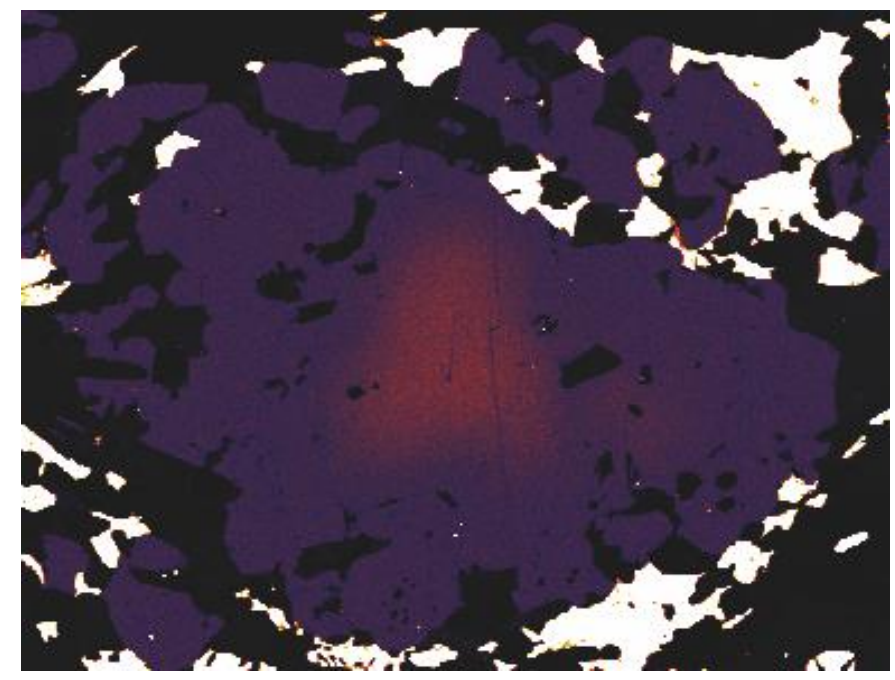

16TG-143-5-Garnet1

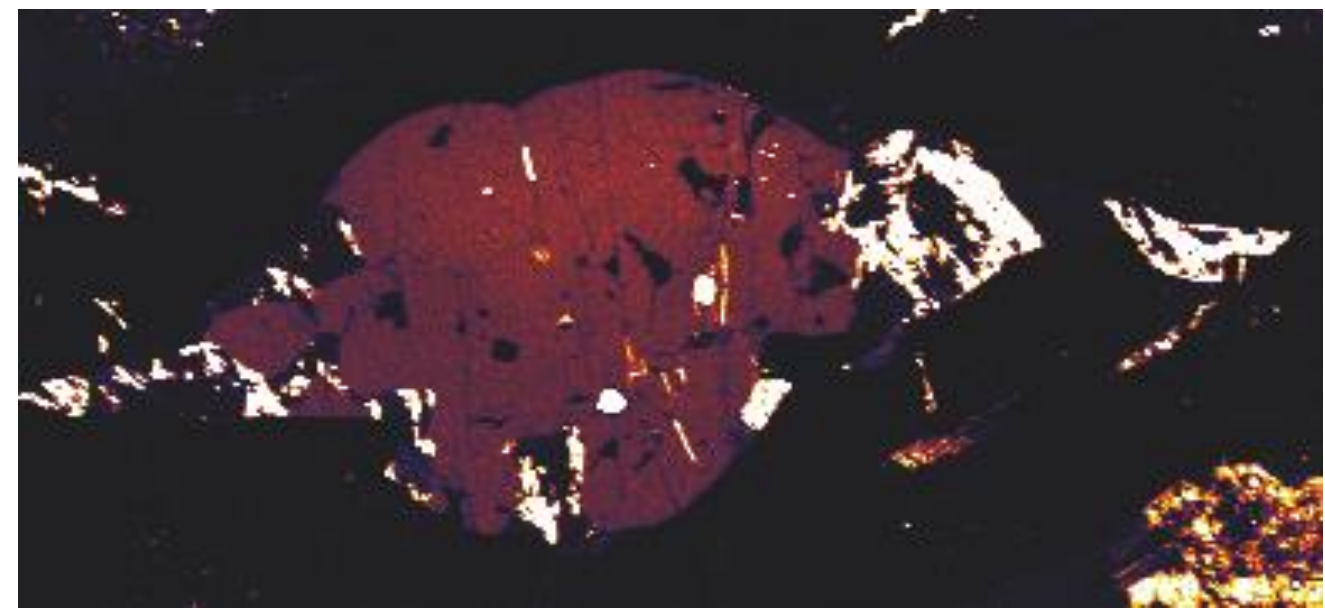

Figure 24: Calcium x-ray microprobe maps of the garnet grains analyzed in the restite. 


\section{TG-143-5-Garnet2}

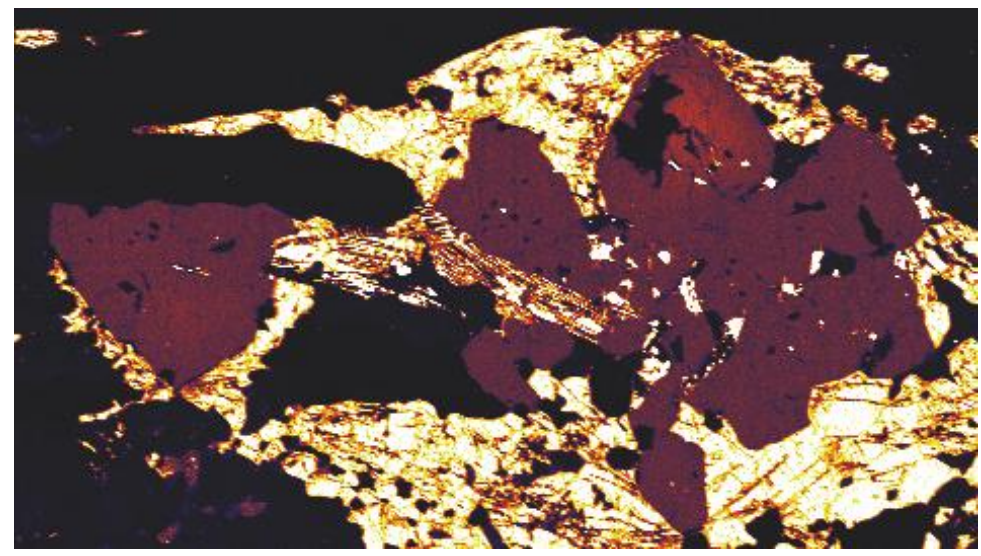

16TG-143-5-Garnet3

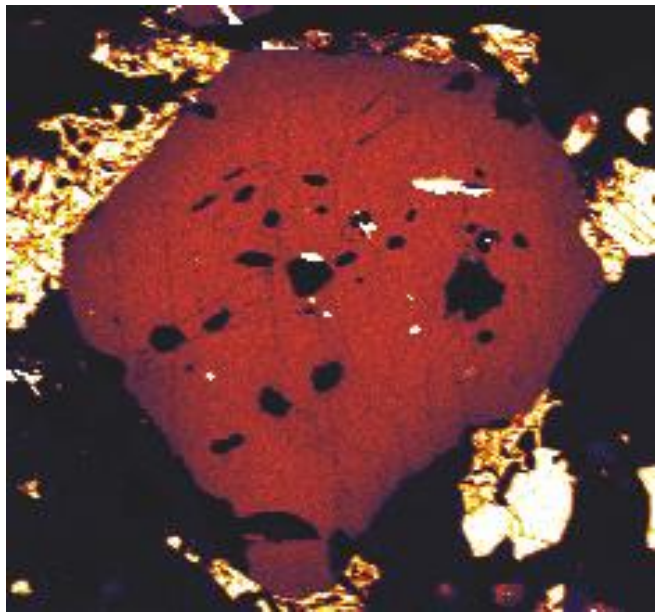

Figure 25: Calcium x-ray microprobe maps of the garnet grains analyzed in the leucosome 


\section{K-FELDSPAR}

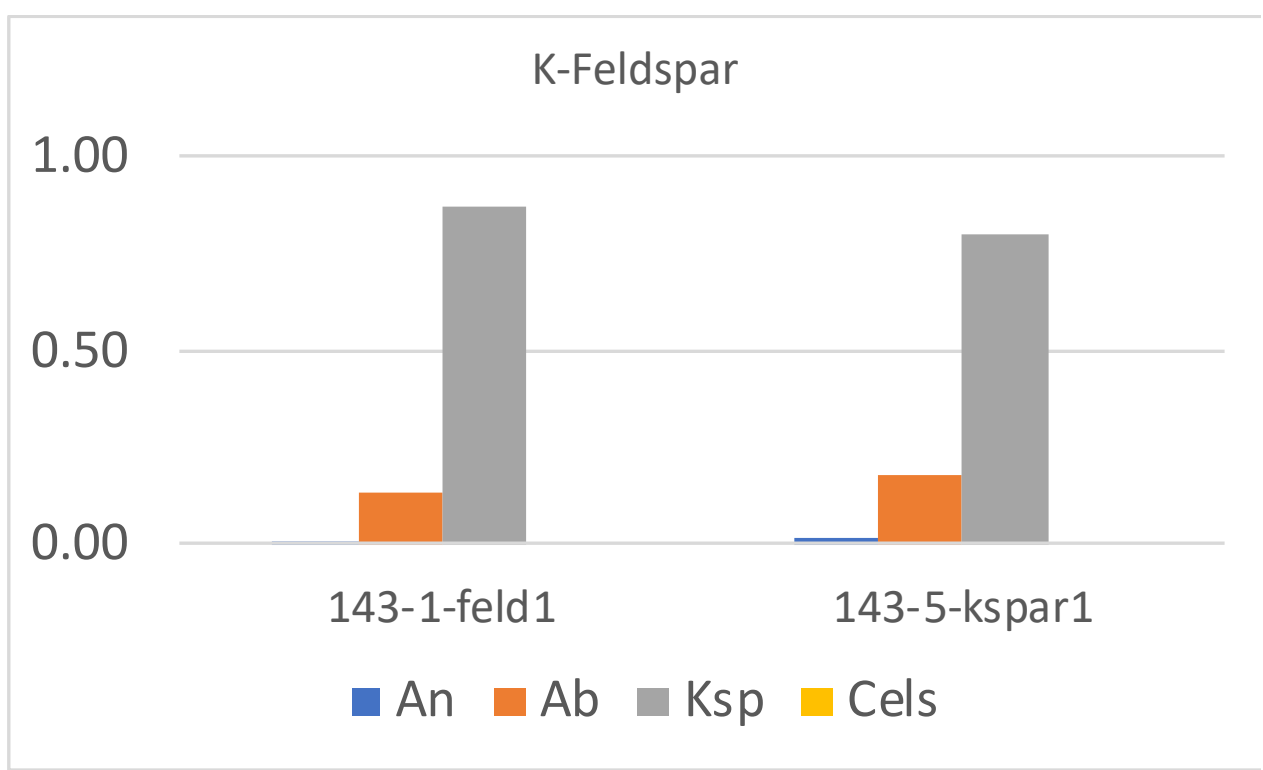

Figure 26: Comparison of the composition of K-feldspar in the restite (143-1) and leucosome (143-5).

\section{TG-143-5-Kspar1}

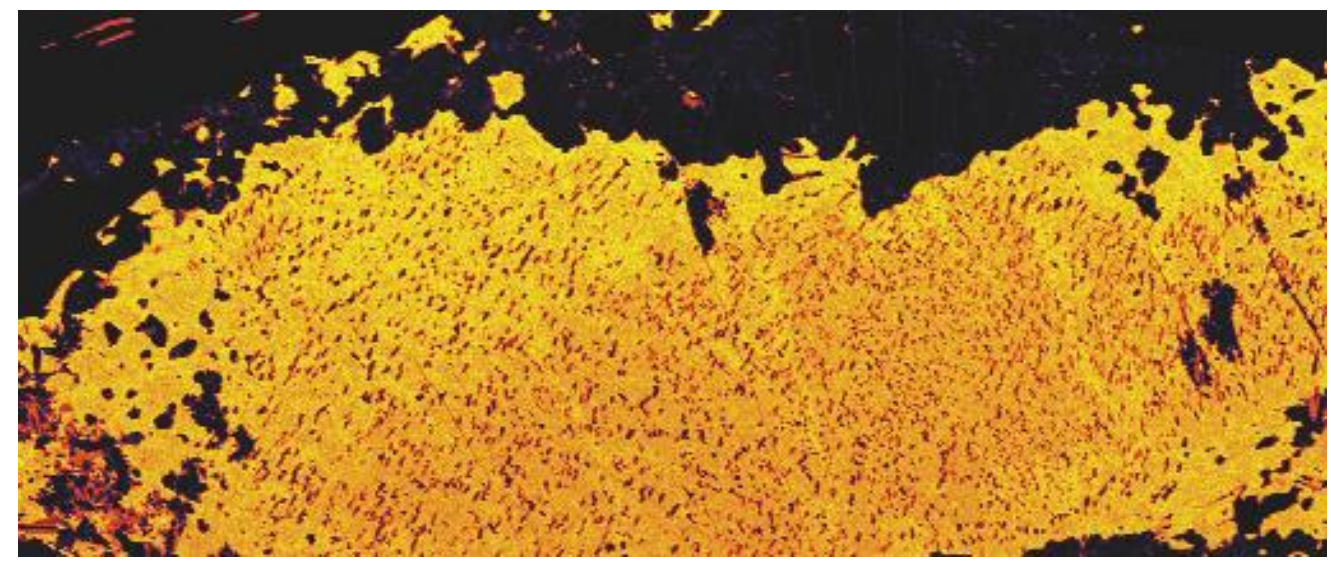

Figure 27: Potassium x-ray microprobe map of K-feldspar in the leucosome (143-5). 


\section{PLAGIOCLASE}

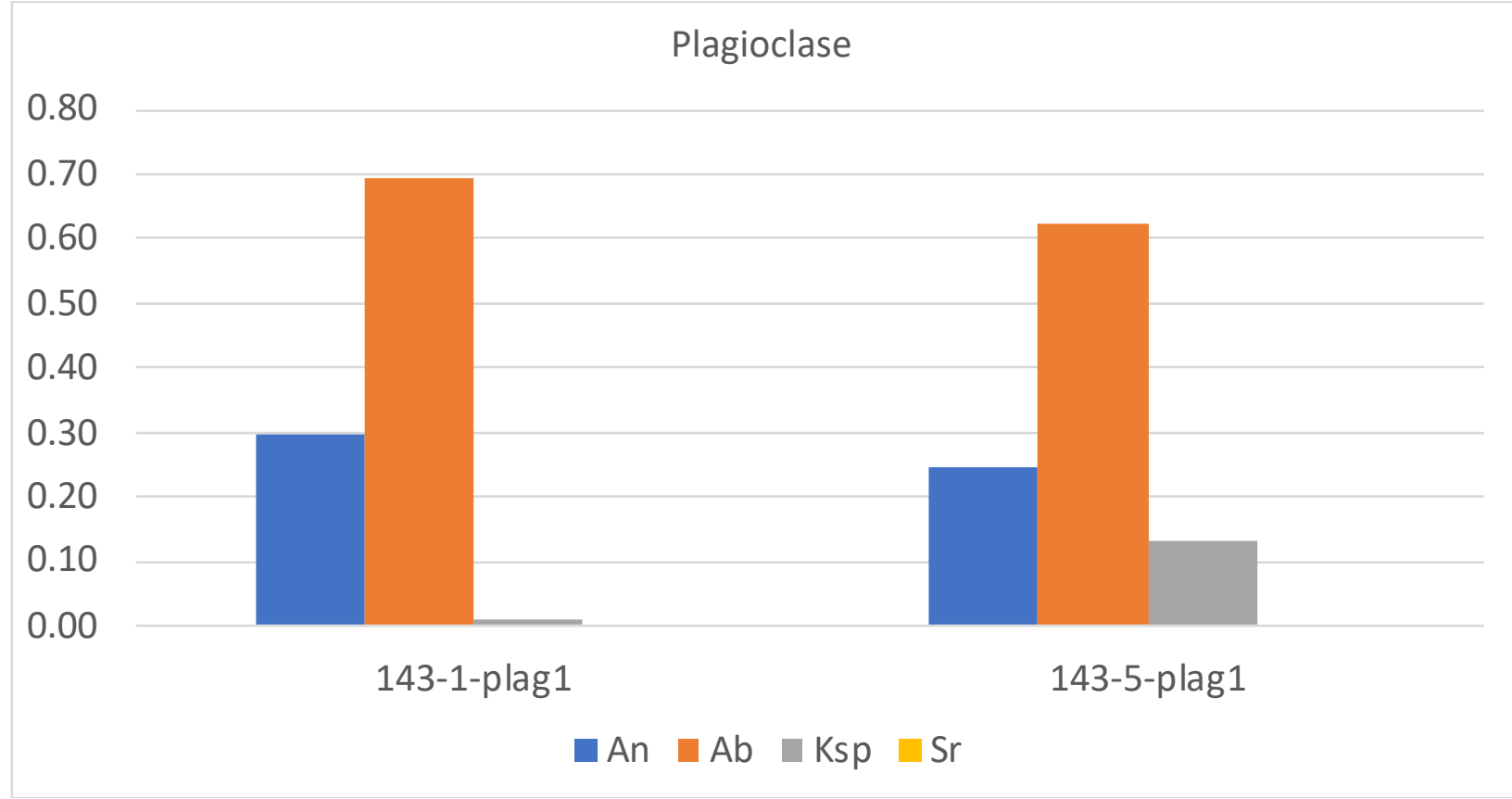

Figure 28: Compositional comparison of plagioclase in the restite (143-1) and leucosome $(143-5)$.

\section{TG-143-5-plag1}

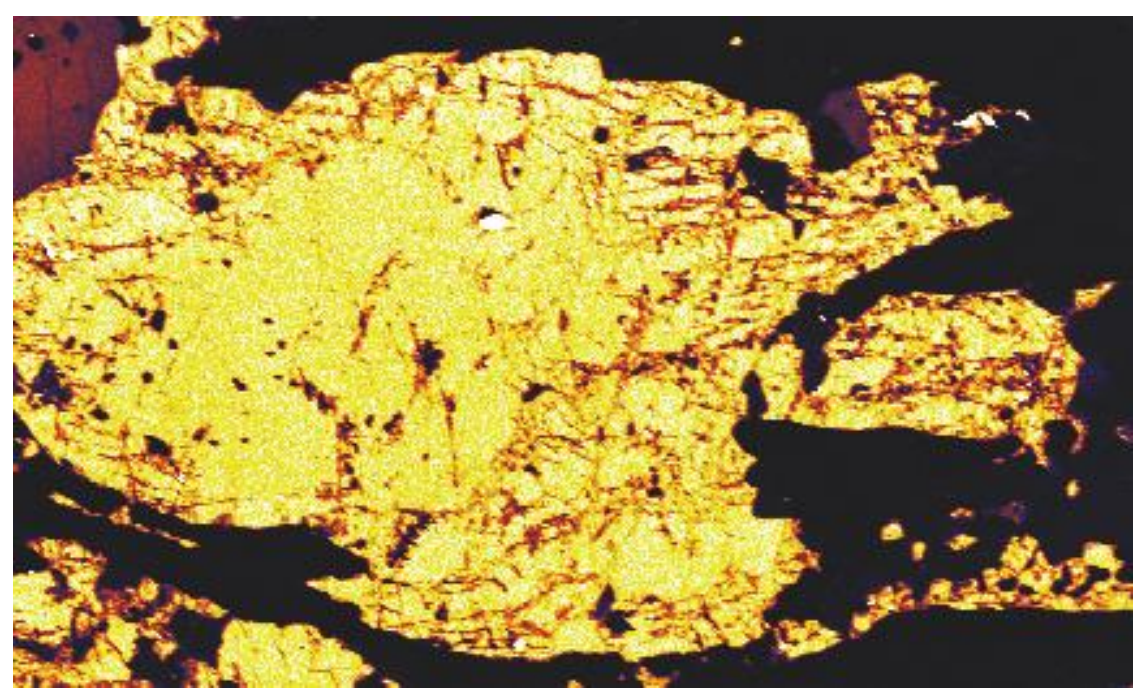

Figure 29: Calcium x-ray microprobe map of plagioclase in the leucosome (143-5). 


\section{BIBLOGRAPHY}

Bickford, M. E., McLelland, J. M., Selleck, B. W., Hill, B. M., \& Heumann, M. J. (2008). Timing of anatexis in the eastern Adirondack Highlands: Implications for tectonic evolution during ca. 1050 Ma Ottawan orogenesis. Bulletin of the Geological Society of America, 120(7-8), 950-961.

Chiarenzelli, J., Regan, S., Peck, W. H., Selleck, B. W., Cousens, B., Baird, G. B., \& Shrady, C. H. (2010). Shawinigan arc magmatism in the Adirondack Lowlands as a consequence of closure of the Trans-Adirondack backarc basin. Geosphere, 6(6), 900-916.

Chiarenzelli, J. R., Selleck, B. W., Lupulescu, M. V., Regan, S. P., Bickford, M. E., Valley, P. M., \& McLelland, J. M. (2017). Lyon Mountain ferroan leucogranite suite: Magmatic response to extensional thinning of overthickened crust in the core of the Grenville orogen. Geological Society of America Bulletin, 129(11-12), 14721488.

Dumond, G., Goncalves, P., Williams, M. L., \& Jercinovic, M. J. (2015). Monazite as a monitor of melting, garnet growth and feldspar recrystallization in continental lower crust. Journal of Metamorphic Geology, 33(7), 735-762.

Foster, G., Parrish, R. R., Horstwood, M. S. A., Chenery, S., Pyle, J., \& Gibson, H. D. (2004). The generation of prograde P-T-t points and paths; a textural, compositional, and chronological study of metamorphic monazite. Earth and Planetary Science Letters, 228(1-2), 125-142.

Foster, G., Gibson, H. D., Parrish, R., Horstwood, M., Fraser, J., \& Tindle, A. (2002). Textural, chemical and isotopic insights into the nature and behaviour of metamorphic monazite. Chemical Geology, 191(1-3), 183-207.

Gasquet, D., Bertrand, J. M., Paquette, J. L., Lehmann, J., Ratzov, G., De Ascenção Guedes, R., ... \& Nomade, S. (2010). Miocene to Messinian deformation and hydrothermal activity in a pre-Alpine basement massif of the French western Alps: new U-Th- $\mathrm{Pb}$ and argon ages from the Lauzière massif. Bulletin de la Société Géologique de France, 181(3), 227-241.

Geisler, T., Schaltegger, U., \& Tomaschek, F. (2007). Re-equilibration of zircon in aqueous fluids and melts. Elements, 3(1), 43-50.

Gibson, H. D., Carr, S. D., Brown, R. L., \& Hamilton, M. A. (2004). Correlations between chemical and age domains in monazite, and metamorphic reactions involving major pelitic phases: An integration of ID-TIMS and SHRIMP geochronology with Y-Th-U X-ray mapping. Chemical Geology, 211(3-4), 237260. 
Heumann, M. J., Bickford, M. E., Hill, B. M., McLelland, J. M., Selleck, B. W., \& Jercinovic, M. J. (2006). Timing of anatexis in metapelites from the Adirondack lowlands and southern highlands: A manifestation of the Shawinigan orogeny and subsequent anorthosite-mangerite-charnockite-granite magmatism. Bulletin of the Geological Society of America, 118(11-12), 1283-1298.

Hoskin, P. W., \& Schaltegger, U. (2003). The composition of zircon and igneous and metamorphic petrogenesis. Reviews in mineralogy and geochemistry, 53(1), 27-62.

Kelly, N. M., Clarke, G. L., \& Harley, S. L. (2006). Monazite behaviour and age significance in poly-metamorphic high-grade terrains: A case study from the western Musgrave Block, central Australia11Abbreviations: After Kretz, 1983. Lithos, 88(14), 100-134.

Kelsey, D. E., Clark, C., \& Hand, M. (2008). Thermobarometric modelling of zircon and monazite growth in melt-bearing systems: Examples using model metapelitic and metapsammitic granulites. Journal of Metamorphic Geology, 26(2), 199-212.

Karioris, F. G., Gowda, K. A., \& Cartz, L. (1981). Heavy ion bombardment of monoclinic ThSiO4, ThO2 and monazite. Radiation Effects, 58(1-2), 1-3.

Kohn, M. J., Wieland, M. S., Parkinson, C. D., \& Upreti, B. N. (2005). Five generations of monazite in Langtang gneisses: Implications for chronology of the Himalayan metamorphic core. Journal of Metamorphic Geology, 23(5), 399-406.

Mclelland, J. M., Selleck, B. W., \& Bickford, M. E. (2014). Tectonic Evolution of the Adirondack Mountains and Grenville Orogen Inliers within the USA. Geoscience Canada, 41, 321-344.

McLelland, J. M., \& Selleck, B. W. (2011). Megacrystic Gore Mountain-type garnets in the Adirondack Highlands: Age, origin, and tectonic implications. Geosphere, 7(5), 1194-1208.

Montel, J. M., Foret, S., Veschambre, M., Nicollet, C., \& Provost, A. (1996). Electron Microprobe dating of monazite. Chemical Geology, 131, 37-53.

Nasdala, L., Lengauer, C. L., Hanchar, J. M., Kronz, A., Wirth, R., Blanc, P., ... Seydoux-Guillaume, A. M. (2002). Annealing radiation damage and the recovery of cathodoluminescence. Chemical Geology, 191(1-3), 121-140.

Pidgeon, R. T., Nemchin, A. A., \& Kinny, P. D. (2000). Fir-Tree and Nebulously Zoned Zircons from Granulite Facies Rocks: Evidence for Zircon Growth and Interaction with Metamorphic Fluids. Journal of Conference Abstracts, 5(2), 798. 
Pyle, J. M., \& Spear, F. S. (2003). Four generations of accessory-phase growth in lowpressure migmatites from SW New Hampshire. American Mineralogist, 88(2-3), $338-351$.

Regan, S., Walsh, G.J., Williams, M.L., Chiarenzelli, J.R., Toft, M., and McAleer, R.J. (2018, in Review) Syn-collisional exhumation of hot middle crust in the Adirondack Mountains: implications for extensional orogenesis in the southern Grenville Province. Geosphere.

Rapp, R. P., Ryerson, P. J., \& Miller, C. F. (1987). Experimental Evidence Bearing on the Stability of Monazite During Crustal Anatexis. Geophysical Research Letters, 14(3), 307-310.

Rivers, T. (1997). Lithotectonic Elements of the Grenville Province: review and tectonic implications, 86, 117-154.

Rivers, T. (2008). Assembly and preservation of lower, mid, and upper orogenic crust in the Grenville Province - Implications for the evolution of large hot long-duration orogens, 167, 237-259.

Rubatto, D. (2017). Zircon: The Metamorphic Mineral. Reviews in Mineralogy and Geochemistry (Vol. 83).

Seydoux-Guillaume, A. M., Montel, J. M., Bingen, B., Bosse, V., de Parseval, P., Paquette, J. L., ... Wirth, R. (2012). Low-temperature alteration of monazite: Fluid mediated coupled dissolution-precipitation, irradiation damage, and disturbance of the U-Pb and Th-Pb chronometers. Chemical Geology, 330-331, 140-158.

Spear, F. S., \& Markussen, J. C. (1997). Mineral zoning, P-T-X-M phase relations, and metamorphic evolution of some Adirondack granulites, New York. Journal of Petrology, 38(6), 757-783.

Spear, F. S., \& Pyle, J. M. (2010). Theoretical modeling of monazite growth in a low-Ca metapelite. Chemical Geology, 273(1-2), 111-119.

Stepanov, A. S., Hermann, J., Rubatto, D., \& Rapp, R. P. (2012). Experimental study of monazite/melt partitioning with implications for the REE, Th and U geochemistry of crustal rocks. Chemical Geology, 300-301, 200-220.

Storm, L. C., \& Spear, F. S. (2005). Pressure, temperature and cooling rates of granulite facies migmatitic pelites from the southern Adirondack Highlands, New York. Journal of Metamorphic Geology, 23(2), 107-130.

Tyson McKinney, S., Cottle, J. M., \& Lederer, G. W. (2015). Evaluating rare earth element (REE) mineralization mechanisms in Proterozoic Gneiss, Music Valley, California. Bulletin of the Geological Society of America, 127(7-8), 1135-1152. 
Valley, P. M., Hanchar, J. M., \& Whitehouse, M. J. (2011). New insights on the evolution of the Lyon Mountain Granite and associated Kiruna-type magnetiteapatite deposits, Adirondack Mountains, New York State. Geosphere, 7(2), 357389.

Wang, J. M., Wu, F. Y., Rubatto, D., Liu, S. R., Zhang, J. J., Liu, X. C., \& Yang, L. (2017). Monazite behaviour during isothermal decompression in pelitic granulites: a case study from Dinggye, Tibetan Himalaya. Contributions to Mineralogy and Petrology, 172(10), 1-30.

Williams, M. L., Jercinovic, M. J., Goncalves, P., \& Mahan, K. (2006). Format and philosophy for collecting, compiling, and reporting microprobe monazite ages. Chemical Geology, 225(1-2), 1-15.

Williams, M. L., Jercinovic, M. J., Harlov, D. E., Budzyń, B., \& Hetherington, C. J. (2011). Resetting monazite ages during fluid-related alteration. Chemical Geology, 283(3-4), 218-225.

Williams, M. L., Jercinovic, M. J., Mahan, K. H., \& Dumond, G. (2018). Electron Microprobe Petrochronology. Reviews in Mineralogy and Geochemistry (Vol. 83).

Williams, M.L, Grover, T., Jercinovic, M.J., Regan, S.P., Pless, C.R., Suarez, K.A. (2018, in review) Constraining the timing and character of extreme crustal melting in the Adirondack Mountains using multiscale compositional mapping and in-situ geochronology. American Mineralogist.

Wong, M. S., Williams, M. L., McLelland, J. M., Jercinovic, M. J., \& Kowalkoski, J. (2012). Late Ottawan extension in the eastern Adirondack Highlands: Evidence from structural studies and zircon and monazite geochronology. Bulletin of the Geological Society of America, 124(5-6), 857-869.

Xing, L., Trail, D., \& Watson, E. B. (2013). Th and U partitioning between monazite and felsic melt. Chemical Geology, 358, 46-53.

Yakymchuk, C., \& Brown, M. (2014). Behaviour of zircon and monazite during crustal melting. Journal of the Geological Society, 171(4), 465-479.

Zhu, X. K., \& O’Nions, R. K. (1999). Monazite chemical composition: Some implications for monazite geochronology. Contributions to Mineralogy and Petrology, 137(4), 351-363. 